\title{
Not Everything Is About Investors: The Case for Mandatory Stakeholder Disclosure
}

\begin{abstract}
Ann M. Lipton ${ }^{\dagger}$
Corporations are required to disclose specific types of information to the public, but only the federal securities laws impose generalized disclosure obligations that produce a holistic overview of corporate operations. While these disclosures are intended to benefit investors, they are accessible to anyone, and thus have long been relied upon by regulators, competitors, employees, and local communities to provide a working portrait of the country's economic life.

Today, that system is breaking down. Congress and the SEC have made it easier for companies to raise capital without triggering securities reporting obligations, allowing modern businesses to grow to enormous proportions while leaving the public in the dark about their operations. Meanwhile, investors' governmentally conferred informational advantage allows them to tilt managers' behavior in their favor, at the expense of consumers, employees, and other corporate stakeholders. As a result, securities disclosures do not provide the comprehensive picture necessary to maintain social control over corporate behavior.

This Article recommends that we explicitly acknowledge the importance of disclosure for noninvestor audiences, and discuss the feasibility of designing a disclosure system geared to their interests. In so doing, this Article excavates the historical pedigree of proposals for stakeholder-oriented disclosure. Both in the Progressive Era, and again during the 1970s, efforts to create generalized corporate disclosure obligations were commonplace. In each era, however, they were redirected towards investor audiences, in the expectation that investors would serve as a proxy for the broader society. As this Article establishes, that compromise is no longer tenable.
\end{abstract}

\footnotetext{
$\dagger$ Michael M. Fleishman Associate Professor in Business Law and Entrepreneurship, Tulane Law School. I am grateful for the thoughtful comments of Benjamin Edwards, Lisa Fairfax, Adam Feibelman, Jill Fisch, Matteo Gatti, George Geis, George Georgiev, Claire Hill, Luke Norris, Nadav Orian Peer, Elizabeth Pollman, Usha Rodrigues, Hillary Sale, Randall Thomas, Robert Thompson, and all of the participants in the Tulane Faculty Workshop, the Third Annual Tulane Corporate and Securities Roundtable, the Richmond Junior Faculty Forum, the National Business Law Scholars Conference, the Vanderbilt Law and Business Workshop, the Seventh Annual Corporate and Securities Litigation Workshop, the Minnesota Faculty Works in Progress Workshop, and the Berkeley Law, Economics and Business Workshop, and the UC Hastings Workshop in Law, Business \& Economics. Errors are entirely my own.
} 


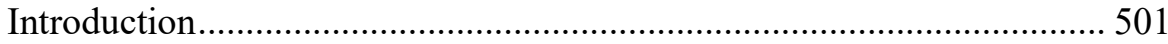

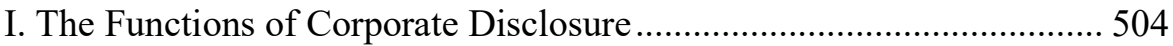

A. Form and Functions of Securities Disclosure........................... 507

B. Functions of Disclosure for Noninvestor Audiences................. 511

1. Contracting and Competition.............................................. 511

2. Community Activism and Political Participation ............... 513

3. Legal Compliance and Lawmaking ................................. 517

II. Investors Versus the Public ............................................................... 519

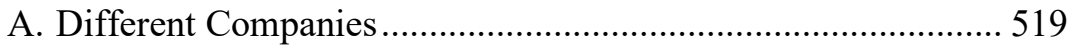

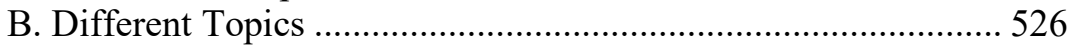

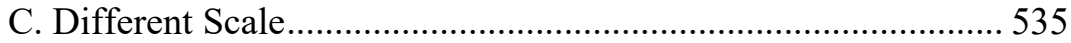

III. Historical Calls for Stakeholder-Oriented Disclosure......................... 537

A. Progressive Era Corporate Regulation .................................... 537

B. 1970s Revitalization of the Corporate Governance

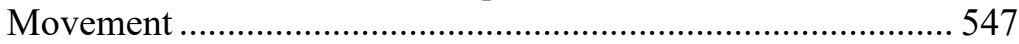

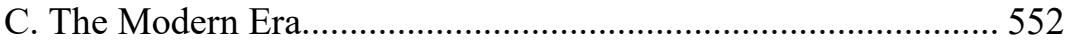

IV. The Perverse Effects of Using the Securities Laws as an All-

Purpose Disclosure Vehicle ................................................................. 553

A. Concealing Motivations for Seeking Disclosure ....................... 553

B. Producing Less Informative Disclosures .................................. 557

C. Privileging Investors and Wealth Maximization ....................... 559

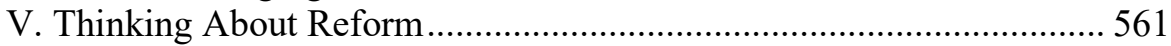

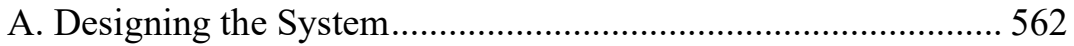

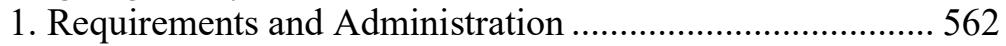

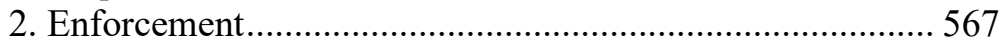

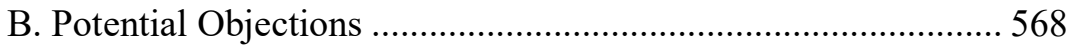

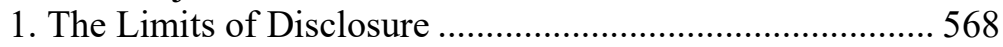

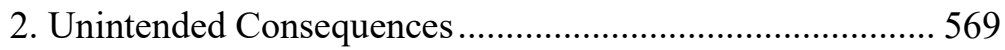

3. Constitutional Concerns................................................... 570

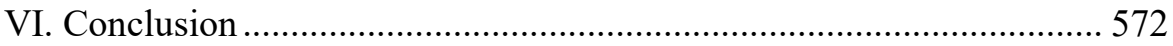


Not Everything Is About Investors

Publicity is justly commended as a remedy for social and industrial diseases. Sunlight is said to be the best of disinfectants; electric light the most efficient policeman.

- Louis D. Brandeis ${ }^{1}$

Introduction

The corporate form confers upon its organizers the ability to aggregate tremendous amounts of wealth while limiting the liability of investors for any harms that the corporation inflicts. As a result, one of the great corporate law challenges has been to develop regulatory systems that enable the productive use of the form while ensuring that corporate wealth and power are channeled in a prosocial direction. These systems exist, most obviously, in the web of substantive regulations that mandate or prohibit certain types of corporate conduct, and, less obviously, in the legal rules that govern the corporate structure itself.

Yet legal rules are necessarily imperfect. Regulators cannot identify every area that requires intervention; not every instance of corporate lawbreaking can be the subject of a lawsuit; and it is not practical to outlaw all unethical corporate activity. But where the law cannot go, markets impose their own constraints. We expect that consumers will refuse to buy dangerous and defective products, workers will avoid firms that pay inadequate wages, and creditors will deny loans to firms that default on their debts. Firms that develop reputations for unsavory business practices may be shunned by communities where they hope to operate, or governments that purchase services. ${ }^{2}$ These reputational markets then make legal systems more effective. Firms that develop reputations for unsavory business practices may attract scrutiny from regulators, inspiring more precise legal prohibitions or greater enforcement efforts. In the end, fear of societal approbation motivates managers to adopt prosocial business practices from the outset.

The catch, as this Article highlights, is that these markets for corporate social responsibility require a certain baseline level of transparency. Public disclosures by corporations can expose antisocial practices (which may then be the subject of protest), permit employees to compare working conditions and wage data, and allow competitors to identify monopoly rents and opportunities for innovation. Corporate secrecy, by contrast, permits antisocial practices to thrive.

Outside of the United States, this principle is understood and incorporated into the regulatory framework. In Europe, for example, all limited liability

1. Louis D. Brandeis, Other People’s Money and How the Bankers Use It 92 (1914).

2. Claire A. Hill, Marshalling Reputation to Minimize Problematic Business Conduct, 99 B.U. L. REV. 1193, 1208 (2019). 
companies must make annual disclosures about their operations and finances. ${ }^{3}$ A new European Union directive mandates that certain large companies regularly disclose information pertaining to their environmental impact, employee relationships, respect for human rights, and anticorruption measures, in order to "meet the needs of investors and other stakeholders [and] to provide consumers with easy access to information on the impact of businesses on society." 4

In this country, however, the situation is far different. Here, the only regulator that requires comprehensive corporate disclosure is the Securities and Exchange Commission (SEC). Whenever a company seeks to raise capital through the public sale of securities, the SEC requires that it file a detailed description of its business and financial condition, periodically updated with new information about its profits, revenues, assets, and general business activities. Regulators, competitors, employees, journalists, and members of the community have all grown to depend on securities disclosures to provide a working portrait of the country's economic life. Yet securities disclosures are not targeted toward the community at large; they are intended for investors alone, and when investors do not require disclosure, the general public is kept in the dark. In the United States, then, corporate transparency is a function of the needs of the investing class.

As this Article demonstrates, America's peculiar system of tying generalized disclosure requirements exclusively to public investment is the result of a series of historical compromises. Both in the Progressive Era, and again during the 1970s, activists, scholars, and politicians sought to enact corporate disclosure schemes in order to make businesses more accountable to society at large. Each time, these efforts were redirected toward investor audiences, in the expectation that investors could serve as a proxy for the broader society.

It is now evident that the compromise carried with it the seeds of its own destruction. Both Congress and the SEC have concluded that the giant institutional investors who dominate contemporary markets require fewer

3. The amount of disclosure required depends on the size of the company. See Darren Bernard et al., Size Management by European Private Firms to Minimize Proprietary Costs of Disclosure, $66 \mathrm{~J}$. ACCT. \& ECON. 94, 96-98 (2018). Additionally, some countries make tax returns public to a greater or lesser extent. Alister Doyle \& Alistair Scrutton, Privacy, What Privacy? Many Nordic Tax Records Are a Phone Call Away, ReUTERS (Apr. 12, 2016), https://www.reuters.com/article/us-panama-tax-nordicsidUSKCN0X91QE [https://perma.cc/M6SN-6QWW]; Jeffrey L. Hoopes et al., Public Tax-Return Disclosure (Nat'l Bureau of Econ. Research, Working Paper No. 24318, 2018), https://www.nber.org/papers/w24318 [https://perma.cc/VP9Y-G5P5].

4. Directive 2014/95/EU, of the European Parliament and of the Council of 22 October 2014 Amending Directive 2013/34/EU as Regards Disclosure of Non-financial and Diversity Information by Certain Large Undertakings and Groups [hereinafter Directive 2014]. The United Kingdom has also recently required that all large firms disclose certain details regarding their governance arrangements. See The Companies (Miscellaneous Reporting) Regulations 2018, SI 2018/860 (UK); see also Paul Hodgson, FRC Issues Corporate Governance Principles for Private Companies, COMPLIANCE WeEK (Dec. 12, 2018), https://www.complianceweek.com/frc-issues-corporate-governance-principles-forprivate-companies/24962.article [https://perma.cc/83VE-D45U]. 
regulatory protections, and they have concomitantly made it easier for issuers to raise capital without becoming subject to mandatory disclosure requirements. The result is that modern businesses can grow to enormous proportions while shielding the details of their operations from public scrutiny.

At the same time, the fact that corporations have generalized disclosure obligations only to investor audiences elevates investors over other constituencies as the central object of corporate concern. Even if the public demands information about firms' environmental impact, their treatment of workers, their political activity, and their use of customer data, corporations are under no obligation to provide it absent a showing of relevance to an investor audience. Investors can then use their informational advantage to influence business decisions, while other stakeholders are left weakened and unprotected. The asymmetry leads to new demands for corporate accountability to noninvestor constituencies.

In response to this reality, most scholars have recommended that we tweak our securities laws, ${ }^{5}$ often by expanding disclosures geared toward investor audiences. ${ }^{6}$ But to do so would only exacerbate the problem by centering investors even further. Thus, this Article takes a different approach. Rather than assume that a disclosure system designed for investor audiences can continue to serve the needs of the general public, this Article recommends that we explicitly acknowledge the importance of disclosure for noninvestor audiences, and discuss the feasibility of designing a disclosure system geared to their interests.

The aim of this Article is to revitalize a conversation that has long been neglected. The assumption — stated or unstated - that all public disclosure must necessarily run through the securities laws has distorted the discourse for decades. Academics, regulators, and advocates have conflated the interests of investor and stakeholder audiences, to the detriment of both. There has been little, if any, discussion of the informational needs of the general public, or when and whether businesses should operate under a duty of public transparency. At the same time, advocates for myriad causes try to flood the securities disclosure system with information relevant to their own idiosyncratic interests, overburdening the SEC and making it more difficult for investor audiences to interpret the information they are given.

This Article proceeds in several parts. Part I describes the functions of mandatory corporate disclosure for both investor and noninvestor audiences. Part II contrasts the informational needs of investors with the informational

5. George Georgiev, Too Big to Disclose: Firm Size and Materiality Blindspots in Securities Regulation, 64 UCLA L. REV. 602, 663 (2017); Donald C. Langevoort \& Robert B. Thompson, "Publicness" in Contemporary Securities Regulation After the JOBS Act, 101 GEO. L.J. 337, 375 (2013).

6. Jennifer S. Fan, Regulating Unicorns: Disclosure in the New Private Economy, 57 B.C. L. Rev. 583, 609 (2016); Cynthia A. Williams, The Securities and Exchange Commission and Corporate Social Transparency, 112 HARV. L. REV. 1197, 1289 (1999). 
needs of the public. Part III describes the history of proposals for stakeholderoriented disclosure, and demonstrates how those proposals were redirected into investor-oriented disclosure regimes. Part IV describes the detrimental effects of relying on investor-oriented disclosure to serve the needs of the general public. Part V sketches out how a stakeholder-oriented disclosure system might be designed today, with a view toward ensuring that all large companies-even nominally "private" ones - operate with a basic level of transparency. Part VI concludes.

\section{The Functions of Corporate Disclosure}

Corporations occupy a peculiar position in our polity. Launched, financed, and operated by nongovernmental actors, they are not public in the traditional sense. Yet they are not quite private, either: They owe their very existence to the grant of a state charter, and, due to their size and power, they may impact the lives of thousands or even millions of people. The corporate form is both necessary and desirable for economic development, but the limited liability that it offers to investors, coupled with its ability to aggregate vast amounts of capital, creates the potential to inflict enormous harm on society. ${ }^{7}$ As a result, since the rise of the great corporations in the late nineteenth century, commenters have debated whether the fundamental purpose of the business corporation is to maximize the wealth of its investors, or whether instead it should be run with a view toward benefitting all "stakeholders" who are affected by corporate activity. ${ }^{8}$

This debate is in many ways misleading. No one disputes that corporations "should be organized and operated to serve the interests of society as a whole," ${ }^{9}$ or that corporate managers should strive to earn returns for their investors while adhering to basic tenets of social responsibility, such as paying taxes due, protecting consumers, providing safe workspaces, and minimizing harm to the environment. The real areas of disagreement concern how legal institutions should be arranged to best bring about these results.

Under the current regime, corporate managers operate under fiduciary duties to further the interests of shareholders. ${ }^{10}$ That alone raises the ire of many commentators, ${ }^{11}$ but, in reality, fiduciary duties are so rarely enforced

7. LAWRENCE MitCHELL, CORPORATE IRRESPONSIBILITY: AMERICA's NEWEST EXPORT 49-65 (2003) (describing the corporate form as an "externalizing machine").

8. See William W. Bratton \& Michael L. Wachter, Shareholder Primacy's Corporatist Origins, 34 J. CORP. L. 99, 143 (2008).

9. Henry Hansmann \& Reinier Kraakman, The End of History for Corporate Law, 89 GEO. L.J. 439, 441 (2001).

10. The precise nature of managers' fiduciary duties is subject to debate, but most commentators would agree that managers must pursue shareholder interests. Id. at 443.

11. Id. at 447 . 
that they likely play little role in how corporations are managed. ${ }^{12}$ Instead, the true driver of corporate decision making is the incentive structure in which it is embedded. Shareholders vote for directors - which permits them to oust those who do not pursue their interests with sufficient vigor-and corporate managers are compensated with pay packages that are designed to align their interests with shareholders. ${ }^{13}$ These features of the corporate form provide managers with powerful incentives to maximize wealth of investors, even at the expense of other groups with whom the corporation interacts. ${ }^{14}$

Yet managers also have incentives to consider nonshareholder constituencies. Environmental law, antitrust law, consumer protection law, antidiscrimination law, labor law, and the like, all force managers to account for the impact of corporate activity on society as a whole. These laws may penalize managers directly for lack of compliance, ${ }^{15}$ and in that respect function as a counterweight to incentives to act in shareholders' interests. More commonly, penalties are imposed on corporations themselves, ${ }^{16}$ threatening to cut into corporate profits and ultimately diminish shareholder wealth. As a result, managers are incentivized to accommodate nonshareholder constituencies as part of their general mandate to act on shareholders' behalf.

In recent years, there has been growing dissatisfaction with this balance, largely due to concerns that the regulatory system is inadequate to constrain the negative externalities associated with corporate conduct. ${ }^{17}$ Corporations that operate internationally may evade control by any single government; corporate complexity may tax the limited resources of regulators; corporate lobbyists may sap political will for vigorous oversight. More broadly, there is general recognition that it is simply inappropriate to rely solely on legal prohibitions to curb all antisocial corporate activity, because it is impossible to specify in advance - let alone enforce laws against - every potential form of corporate misbehavior. Just as we expect that natural persons will comply with social norms without imposing legal mandates that they do so in every respect, it is

12. David G. Yosifon, The Law of Corporate Purpose, 10 Berkeley Bus. L.J. 181, 223

13. Jeffrey N. Gordon, The Rise of Independent Directors in the United States, 1950-2005: Of Shareholder Value and Stock Market Prices, 59 STAN. L. REV. 1465, 1530-31 (2007).

14. See generally Leo E. Strine, Jr., Corporate Power Is Corporate Purpose I: Evidence from My Hometown, 33 OXFORD REV. ECON. POL'Y 176 (2017) (explaining that shareholders' power within the corporate form ensures that managers will elevate their interests over the interests of other constituencies).

15. See, e.g., Former CEO of Volkswagen AG Charged with Conspiracy and Wire Fraud in Diesel Emissions Scandal, U.S. DEP’T. OF JUST. (May 3, 2018), https://www.justice.gov/opa/pr/formerceo-volkswagen-ag-charged-conspiracy-and-wire-fraud-diesel-emissions-scandal [https://perma.cc/587X-H5NS].

16. See, e.g., Wal-Mart Pleads Guilty to Federal Environmental Crimes, Admits Civil Violations and Will Pay More Than $\$ 81$ Million, U.S. DEP'T. OF JuST. (Sept. 15, 2014), https://www.justice.gov/opa/pr/wal-mart-pleads-guilty-federal-environmental-crimes-admits-civilviolations-and-will-pay-more [https://perma.cc/EG9X-QJ3R].

17. See, e.g., Kent Greenfield, The Failure of Corporate LaW 16-21 (2006); David YOSIFON, CORPORATE FRICTION 31-34 (2018). 
hoped that corporations, as well, will adhere to certain baseline standards of ethical behavior even absent threat of formal legal penalty. ${ }^{18}$ But if corporate managers are incentivized to pursue shareholder wealth maximization and constrained only by what the law prohibits, corporations will violate these norms.

In this state of affairs, markets, both economic and social, fill the spaces that law cannot reach. ${ }^{19}$ In order to earn profits, corporations not only have to produce goods and services that attract customers, but they also must generate enough reputational capital to maintain relationships with suppliers, employees, and other critical stakeholders. ${ }^{20}$ Corporations that develop poor reputationsfor creating harmful products, for mistreating their workforce, for overcharging clients - will find it more difficult to operate. ${ }^{21}$ Journalists will spotlight their behavior; consumers avoid them; investors and other suppliers of capital will flee; and competitors will challenge their position. Regardless of whether managers are expected-via fiduciary duties or otherwise-to maximize shareholder wealth, an effective system of "soft" corporate discipline ensures that the pursuit of shareholder wealth is aligned with the well-being of the broader society in which the corporation operates. ${ }^{22}$

But, like any market, the market for corporate responsibility requires transparency to operate effectively. Corporate stakeholders cannot pressure managers to change behaviors of which they are unaware. ${ }^{23}$ Transparency also makes the formal legal system more effective: Corporations that develop reputations as "bad actors" may become political targets; corporations with better reputations may enjoy a degree of regulatory forbearance. ${ }^{24}$ Yet, other than the federal securities laws, the United States has no general requirement that businesses disclose the details of their internal operations. The result is that the public is deprived of valuable insights that could be used to exert social control over corporate behavior.

18. Einer Elhauge, Sacrificing Corporate Profits in the Public Interest, 80 N.Y.U. L. REV. 733, 748-53 (2005); Claire A. Hill, Repugnant Business Models: Preliminary Thoughts on a Research and Policy Agenda, 74 WASH. \& LeE L. REV. 973, 988 (2017).

19. Larry E. Ribstein, Accountability and Responsibility in Corporate Governance, 81 NOTRE DAME L. REV. 1431, 1433 (2006).

20. Craig Deegan, Introduction: The Legitimising Effect of Social and Environmental Disclosure - A Theoretical Foundation, 15 ACCT. AudiTING \& ACCOUNTABILITY J. 282 (2002); Hillary A. Sale, The Corporate Purpose of Social License (June 20, 2019) (unpublished article), https://ssrn.com/abstract=3403706 [https://perma.cc/6H2W-33K5] [hereinafter Social License].

21. Hill, supra note 2, at 1208.

22. Cf. Jill E. Fisch, Measuring Efficiency in Corporate Law: The Role of Shareholder Primacy, 31 J. CORP. L. 637, 645 (2006) (describing the view that corporate interests and societal interests ultimately converge).

23. Roy Shapira \& Luigi Zingales, Is Pollution Value Maximizing? The DuPont Case (Nat'l Bureau of Econ. Research, Working Paper No. 23866, 2017), https://www.nber.org/papers/w23866 [https://perma.cc/KK3Y-6DD2].

24. Sale, supra note 20 , at $40-41$. 
Not Everything Is About Investors

\section{A. Form and Functions of Securities Disclosure}

Businesses that operate in the United States are constantly required to disclose information. Both state and federal law require merchants to disclose product and service information to consumers. ${ }^{25}$ Federal law requires employers to disclose workplace hazards to employees. ${ }^{26}$ Data on the racial and gender makeup of a firm's workforce must be disclosed to the Equal Employment Opportunity Commission, ${ }^{27}$ and detailed financial information must be disclosed to the IRS. These disclosures, however, are specific and targeted for particular purposes; many are made exclusively to government agencies and available to the public, if at all, only through a lengthy and difficult FOIA process. ${ }^{28}$

There is, however, one regulatory sphere that requires a holistic set of disclosures for public consumption: the federal securities laws. Whenever a company makes its securities - namely, its stock, or its bonds - available for generalized trading, it becomes subject to a host of public disclosure requirements.

There are three paths by which a company becomes "public" and thus obligated to disclose information pursuant to the federal securities laws. First, the company may directly undertake to sell securities to the public. The question whether a sale counts as "public" or "private" is a complex one, but, in general, public sales are those made on an unrestricted basis to a dispersed set of investors who have no special qualifications or inside information. ${ }^{29}$ If a company chooses to sell its securities in this manner, it must file a publicly available registration statement with the SEC and additional reports every quarter thereafter, ${ }^{30}$ with emergency updates on an as-needed basis. ${ }^{31}$ The issuing company must also file a copy of its proxy statement in advance of any stockholder meeting. ${ }^{32}$

Second, the company may choose to list its securities for trading on a national exchange. Typically, an exchange listing is accompanied by a public sale of securities but not always; for example, the company may sell small amounts of securities privately over a prolonged period and later decide to

25. See, e.g., 15 U.S.C. $§ 1601$ (a)-(b) (2018); Pub. L. No. 101-535, 104 Stat. 2353 (2016); 21 C.F.R. pt. 801 (2019); see also Omri Ben-Shahar \& Carl E. Schneider, The Failure of Mandated Disclosure, 159 U. PA. L. REV. 647, 653-62 (2011).

26. 29 C.F.R. $\S 1910.1200(2019)$.

27. Id. $\$ 1602.7$.

28. See, e.g., Jamillah Williams, Diversity as a Trade Secret, 107 GEO. L.J. 1684, 1688 (2019). See generally David Pozen, Freedom of Information Beyond the Freedom of Information Act, 165 U. PA. L. REV. 1097 (2017) (describing FOIA's procedural obstacles).

29. See, e.g., SEC v. Ralston Purina, 346 U.S. 119 (1953).

30. 15 U.S.C. $\S \S 77$ e, $\S 78$ o (2018); 17 C.F.R. $\S 240.15$ d-13 (2019).

31. 17 C.F.R. $\S 249.308(2019)$.

32. Id. $\S \S 240.14 \mathrm{a}-6,240.14 \mathrm{a}-101$. 
make those securities available on an exchange. ${ }^{33}$ Once it does so, it, too, becomes obligated to file a standard package of operational and financial disclosures with the SEC - where they can be accessed by the general publicand to file quarterly updates and proxy statements. ${ }^{34}$

Third, a company may become subject to federal disclosure requirements if a certain number of its securities has generally fallen into public hands, even without a formal public offering. ${ }^{35}$ This might occur if, again, the company sells securities privately over a prolonged period and a large enough segment of the public ends up holding its stock or bonds.

Whatever path the company takes to becoming "public," once it does so, it remains subject to the securities disclosure regime, at least so long as the triggering securities remain in public hands. ${ }^{36}$ Among other matters, these companies must provide detailed information about cash flows; ${ }^{37}$ assets; ${ }^{38}$ capital structure ${ }^{39}$ trends likely to affect liquidity, profits, and capital resources; ${ }^{40}$ compensation paid to top executives and the objectives of the compensation program; ${ }^{41}$ and a variety of other topics that are, or could be, relevant to companies' future financial performance and, thus, to their investors. $^{42}$

Though Congress has set forth the general disclosure regime via the Securities Act of 1933 and the Securities Exchange Act of 1934, the details of these disclosures and the means of their dissemination are mostly governed by regulations promulgated by the SEC. ${ }^{43}$ The SEC's mandate is to protect investors, facilitate capital raising, and encourage the development of healthy capital markets, ${ }^{44}$ and disclosure is a critical (though not the only ${ }^{45}$ ) mechanism for accomplishing these goals.

33. Marc D. Jaffe et al., Spotify Case Study: Structuring and Executing a Direct Listing, Harv. L. SCH. FORUM ON CORP. GOVERnANCE \& Fin. Reg. (July 5, 2018), https://corpgov.law.harvard.edu/2018/07/05/spotify-case-study-structuring-and-executing-a-directlistingv [https://perma.cc/85Z2-BVAC].

34. 15 U.S.C. $\S \S 781,78 \mathrm{~m}(2018) ; 17$ C.F.R. $\S 240.13 \mathrm{a}-13$ (2019).

35. 15 U.S.C. $\S \S 781,78 \mathrm{~m} ; 17$ C.F.R. $\S 240.13 \mathrm{a}-13$.

36. 17 C.F.R. $\S 240.12 h-3$ (2019).

37. Id. $\S 210.3-02$.

38. Id. $\S \S 229.301-302$.

39. Id. §210.3-01.

40. Id. $\$ 229.303$.

41. Id. $\S 229.402$.

42. See generally id. pt. 229 (identifying other aspects of corporate performance that must be publicly disclosed under various conditions). (2017).

43. Usha Rodrigues, Dictation and Delegation in Securities Regulation, 92 IND. L.J. 435, 456

44. What We Do, U.S. SEC. \& EXCH. COMM'N, http://www.sec.gov/about/whatwedo.shtml [https://perma.cc/SR9B-U3M5]. Congress has mandated that when the SEC engages in rulemaking, it must consider "the protection of investors, whether the action will promote efficiency, competition, and capital formation." National Securities Market Improvement Act of 1996, Pub. L. No. 104-290, § 106(b), 110 Stat. 3416, 3424 (1996).

45. See Steve Thel, The Original Conception of Section 10(b) of the Securities Exchange Act, 42 STAN. L. REV. 385, 389-92 (1990). 
Disclosure advances the SEC's mission in a number of ways. First and most fundamentally, it protects investors against fraud. ${ }^{46}$ Second, disclosure allows investors to compare investment opportunities and reward stronger businesses with lower costs of capital, resulting in an efficient allocation of resources throughout the economy.$^{47}$ Disclosure also corrects asymmetries of information, protecting investors against exploitation by better-informed insiders. ${ }^{48}$

Finally, disclosure operates to shape the behavior of corporate managers. Though the substantive duties owed to investors - the duties of care and loyalty-are technically imposed by state law rather than federal law, disclosure indirectly assists in the enforcement of these duties. It deters managers from engaging in self-dealing and other aggrandizing misconduct, ${ }^{49}$ and allows investors to detect, and discipline, such misconduct when it occurs. ${ }^{50}$ Additionally, the obligation to disclose indirectly ensures that corporate managers will monitor the business at least sufficiently to gather, synthesize, and report the required data. ${ }^{51}$

That said, because the securities laws are the only source for holistic disclosures about corporate operations, securities disclosures are consumed by other corporate stakeholders. Examples abound: Regulators may rely on securities disclosures to identify red flags of lawbreaking, ${ }^{52}$ to gain a general understanding of business activity in their sphere of influence, ${ }^{53}$ and to make

46. See Michael D. Guttentag, Protection from What? Investor Protection and the JOBS Act, 13 U.C. DAVIS Bus. L.J. 207, 223 (2013).

47. John C. Coffee, Jr., Market Failure and the Economic Case for a Mandatory Disclosure System, 70 VA. L. REV. 717, 734 (1984) ("[I]f we view the securities market as the principal allocative mechanism for investment capital, the behavior of securities prices is important not so much because of their distributive consequences on investors but more because of their effect on allocative efficiency. In this light, it is important not only that the game be fair, but that it be accurate - that is, that capital be correctly priced."); Merritt B. Fox, Securities Disclosure in a Globalizing Market: Who Should Regulate Whom, 95 Mich. L. REV. 2498, 2544-45 (1997); Zohar Goshen \& Gideon Parchomovsky, The Essential Role of Securities Regulation, 55 DUKE L.J. 711, 713-16 (2006).

48. Goshen \& Parchomovsky, supra note 47, at 751-52; Guttentag, supra note 46, at 224-27.

49. Joel Seligman, The Transformation of Wall Street 39-40 (3d ed. 2003) (“[A] primary enduring mission of the SEC has been to compel disclosure of data by firms involved in the securities markets, indirectly inducing these firms to avoid illegal or embarrassing activities.").

50. Goshen \& Parchomovsky, supra note 47, at 753-54; Guttentag, supra note 46, at 227-29; Robert B. Thompson \& Hillary A. Sale, Securities Fraud as Corporate Governance: Reflections upon Federalism, 56 VAND. L. REV. 859, 873 (2003).

51. Philip A. Loomis Jr. \& Beverly K. Rubman, Corporate Governance in Historical Perspective, 8 HOFSTRA L. REV. 141, 165-66 (1979); Thompson \& Sale, supra note 50, at 873-74.

52. For example, information disclosed to investors and included in securities filings may provide evidence of antitrust violations. Matt Kempner, Airlines Just Can't Say 'Buh-Bye' to Antitrust Issues, ATLANTA J. CONST. (July 10, 2015), https://www.ajc.com/news/transportation/airlines-just-cansay-buh-bye-antitrust-issues/FJqnObBaFDDRmAnarfkCSM [https://perma.cc/AU42-WZEW]; Christopher Rowland, Prescription Drug Wholesalers Reaped Windfall from Alleged Price-Fixing, WASH. POST (Feb. 1, 2019), https://www.washingtonpost.com/business/economy/prescription-drugwholesalers-reaped-windfall-from-alleged-price-fixing/2019/01/31/b8ed6130-230f-11 e9-81fdb7b05d5bed90_story.html [https://perma.cc/D5SV-58FR].

53. Fan, supra note 6, at 599-602. 
critical policy decisions. ${ }^{54}$ Employees rely on reported profit margins to strike for higher wages.$^{55}$ Competitors use securities filings to benchmark their own financial decisions to others in their industry. ${ }^{56}$ Lenders use securities filings to judge the creditworthiness of potential borrowers. ${ }^{57}$ Obviously, these effects deprive the issuing company of rents, but they also benefit society overall. ${ }^{58}$

On a more general level, securities disclosures facilitate social control over business activity. Hillary Sale calls this effect "publicness," namely, the process of subjecting corporate power to the same standards of accountability that are applied to governmental power. ${ }^{59}$ Issuers understand that, via securities disclosure, they are subject to scrutiny by regulators, journalists, and the general public, and conduct themselves accordingly. ${ }^{60}$ The possibility that illegal or unethical behavior will be revealed - exposing the company both to legal liability and social opprobrium ${ }^{61}$ - helps deter issuers from engaging in such behavior in the first place. ${ }^{62}$ As a result, securities disclosures ensure general compliance with laws that extend well outside the realm of finance, protecting both employees and surrounding communities from corporate antisocial activity. ${ }^{63}$ $(2013)$

54. Urska Velikonja, The Cost of Securities Fraud, 54 WM. \& MARY L. REV. 1887, 1937-38

55. Steven Greenhouse, The Return of the Strike, AM. PROSPECT (Jan. 3, 2019), https://prospect.org/article/return-strike [https://perma.cc/VHC2-NYZ9]. A former Ford accountant recently explained that the company was concerned that mandated disclosures provided bargaining advantages to union members or contracting counterparties. See Nicola M. White, More Detailed U.S. Income Statements May Be Elusive Goal, BlOOMBERG (Sept. 25, 2019), https://news.bloombergtax.com/financial-accounting/more-detailed-u-s-income-statements-may-beelusive-goal [https://perma.cc/C46G-ZT9D].

56. Fox, supra note 47, at 2550-51; Georgiev, supra note 5, at 652-53; Sean Cao et al., Copycatting and Public Disclosure: Direct Evidence from Peer Companies' Digital Footprints (Jan. 9, 2019) (unpublished article), https://ssrn.com/abstract=3280744 [https://perma.cc/BP9Z-SHRV]. Conversely, when companies lie about their financial results, they may induce competitors to enter unprofitable lines of business, potentially creating industry-wide distortions. See Velikonja, supra note 54. at 1891-92.

57. See, e.g., U.S. Mortg., Inc. v. Saxton, 494 F.3d 833, 837 (9th Cir. 2007); see also Fan, supra note 6, at 602. After private company WeWork filed the initial paperwork for a public offering of its securities, its contracting counterparties became so concerned about its financial stability that they began to court its competitors. See Reeves Wiedeman, The Sun Sets on We, N.Y. MAG. (Sept. 30, 2019), http://nymag.com/intelligencer/2019/09/what-happened-at-we-why-wework-postponed-its-ipo.html [https://perma.cc/62NV-6J9V].

58. Georgiev, supra note 5 , at 653 .

59. Hillary A. Sale, The New “Public” Corporation, 74 L. \& CONTEMP. ProBS. 137, 137-38 (2011) [hereinafter Sale, New Public]; see also Langevoort \& Thompson, supra note 5, at 340 ("[W]e suspect that some portion of what we call securities regulation follows from an effort to create more accountability of large, economically powerful business institutions that is only loosely coupled with orthodox (and arguably more measurable) notions of investor protection.").

60. Sale, New Public, supra note 59, at 144; see also Renee M. Jones, The Unicorn Governance Trap, 166 U. PA. L. REV. ONLINE 165, 171, 179 (2017).

61. Hill, supra note 18 , at 979.

62. Jones, supra note 60 , at 179.

63. Id. at $179-82$. 
Yet despite the positive effects of securities disclosure - and those effects are among the laws' purposes ${ }^{64}$ - the mechanism by which those effects are achieved is by centering investors: generating information for their consumption, and forcing managers to attend to their interests. ${ }^{65}$ Securities disclosures may benefit society at large, but they are not designed with the whole of society in mind.

\section{B. Functions of Disclosure for Noninvestor Audiences}

By providing critical information not only to investors but also to other corporate stakeholders, the securities laws have functioned as a proof of concept of the broad importance of corporate disclosure. Though there are undoubtedly countless possible benefits that flow from corporate transparency, in general, these fall into three basic categories.

\section{Contracting and Competition}

Disclosures may benefit a variety of audiences that have financial relationships with a corporation. Most obviously, employees and even customers can use information about profit margins to drive harder bargains. ${ }^{66}$ General information about salaries in a particular field or at a particular company — currently very difficult to obtain ${ }^{67}$ — can help all workers negotiate for better arrangements, and in particular can help women and people of color

64. Seligman, supra note 49, at 39-40; Loomis Jr. \& Rubman, supra note 51, at 165, 168; Adam C. Pritchard \& Robert B. Thompson, Securities Law and the New Deal Justices, 95 VA. L. ReV. 841, 846-49 (2009).

65. H.R. REP. No. 73-1383, at 5 (1934) (“[A]s management became divorced from ownership and came under the control of banking groups, men forgot that they were dealing with the savings of men and the making of profits became an impersonal thing. When men do not know the victims of their aggression they are not always conscious of their wrongs."); S. REP. No. 73-47, at 1 (1933) ("The purpose of this bill is to protect the investing public and honest business. The basic policy is that of informing the investor of the facts concerning securities to be offered for sale in interstate and foreign commerce and providing protection against fraud and misrepresentation."); 77 CONG. REC. 937 (1933) (quoting Roosevelt: "every issue of new securities to be sold in interstate commerce shall be accompanied by full publicity and information, and ... no essentially important element attending the issue shall be concealed from the buying public."); Guttentag, supra note 46, at 212-214; Loomis Jr. \& Rubman, supra note 51, at 166 (quoting President Roosevelt: "What we seek is a return to a clearer understanding of the ancient truth that those who manage . . corporations ... handling or using other people's money are trustees acting for others."); Williams, supra note 6, at 1218 ("The idea of corporate powers being held in trust for the shareholders loudly echoes in the legislative history of the Securities Act and the Exchange Act."). at $1924-25$.

66. Fox, supra note 47, at 2550-51; Georgiev, supra note 5, at 653; Velikonja, supra note 54,

67. Deborah Thompson Eisenberg, Money, Sex, and Sunshine: A Market-Based Approach to Pay Discrimination, 43 ARIz. ST. L.J. 951 (2011); Laura M. Holson, Should You Tell the World How Much Money You Make?, N.Y. TIMES (May 10, 2019), https://www.nytimes.com/2019/05/10/business/salary-transparency-ask-a-manager.html [https://perma.cc/2K8R-65VJ]. 
correct for systematic disadvantages they might otherwise experience. ${ }^{68}$ And wages are not the only issue: Disclosure of legal complaints lodged against employers (as employees have demanded in the context of sexual harassment ${ }^{69}$ ) may help vulnerable groups press for better working conditions or, if necessary, avoid employers with poor reputations. Merely the act of forcing managers to attend to these matters by collecting and publicizing such information can prod them to rectify problems that might otherwise have gone unnoticed. ${ }^{70}$

Disclosure also inspires new forms of entrepreneurship. Jennifer Fan points out that when new businesses enter an area, especially if they have innovative models, other, auxiliary businesses may adapt to provide support. ${ }^{71}$ Disclosure aids these efforts, promoting a more efficient and developed economy.

Finally, disclosure can aid competition. Competing companies may rely on information about lines of business, sales figures, and profit margins of their peers to make decisions about whether and where to make their own investments, and to benchmark their own expenses and sales growth. ${ }^{72}$ Indeed, the argument for light-touch antitrust regulation-trusting that supracompetitive profits will attract new entrants ${ }^{73}$ - depends on potential competitors becoming aware of those opportunities.

Sotheby's, the famous art dealer, provides a timely example. For several decades, Sotheby's was publicly traded, and thus provided investors with quarterly financial information. But in 2019, Sotheby's was sold to a private investor, bringing an end to its reporting obligations. When the news was

68. Eisenberg, supra note 67, at 997; Rebecca Greenfield, Making Salary Information Public Helps Close the Gender Pay Gap, BloOMBERG (Dec. 5, 2018), https://www.bloomberg.com/news/articles/2018-12-05/making-salary-information-public-helps-closethe-gender-pay-gap [https://perma.cc/9TFQ-8KEK]; Kristin Wong, Want to Close the Pay Gap? Pay Transparency Will Help, N.Y. TIMES (Jan. 20, 2019), https://www.nytimes.com/2019/01/20/smarterliving/pay-wage-gap-salary-secrecy-transparency.html [https://perma.cc/WKD7-8A4N]; Morten Bennedsen et al., Do Firms Respond to Gender Pay Gap Transparency? (Nat'l Bureau of Econ. Research, Working Paper No. 25435, 2019), https://www.nber.org/papers/w25435 [https://perma.cc/9B4Y-JA4R].

69. Cynthia Estlund, Just the Facts: The Case for Workplace Transparency, 63 STAN. L. REV. 351, 364-66, 369-73 (2011) (arguing that disclosure to employees of workplace conditions will help them bargain for appropriate employment terms); Jena McGregor, Google and Facebook Ended Forced Arbitration for Sexual Harassment Claims. Why More Companies Could Follow., WASH. POST (Nov. 12 , 2018), https://www.washingtonpost.com/business/2018/11/12/google-facebook-ended-forcedarbitration-sex-harassment-claims-why-more-companies-could-follow [https://perma.cc/Q7D8-9RFS] [(describing protests by employees and prospective employees at tech firms and law firms) [https://perma.cc/Q7D8-9RFS].

70. David W. Case, Corporate Environmental Reporting as Information Regulation: A Law and Economics Perspective, 76 U. COLO. L. REV. 379, 385-86 (2005) (describing the effect in the context of environmental reporting); Estlund, supra note 69, at 377 (describing the effect in the context of workplace hazards).

71. Fan, supra note 6, at 602 .

72. See supra Section I.A; see also Bernard et al., supra note 3, at 99.

73. See George L. Priest, The Abiding Influence of The Antitrust Paradox, 31 HARV. J.L. \& PUB. POL'y 455, 457 (2008). 
announced, the entire industry braced for the loss of critical data concerning "margins, executive compensation, strategy, capital allocation and the stock's reaction to major economic and political forces." 74

\section{Community Activism and Political Participation}

Illegal, immoral, or unethical behavior can be policed by consumers, employees, and other counterparties whose custom is crucial to corporate operations. Disclosure is, self-evidently, critical to these initiatives. ${ }^{75}$

The most obvious form of social pressure is the customer boycott, or its more mild cousin, customer distaste. ${ }^{76}$ Though many have questioned whether boycotts have a genuine effect on sales, there is strong evidence that companies are concerned for their reputation and will reform their practices in order to avoid negative publicity. ${ }^{77}$ The mere fact that corporations are willing to expend significant resources to do so suggests that negative publicity has a real economic impact, ${ }^{78}$ and, in general, the greater a company's media visibility, the more likely it is to invest in socially responsible measures to maintain its reputation. ${ }^{79}$ The power of social condemnation is only likely to increase:

74. Katya Kazakina et al., Private Deal for Sotheby's Pushes Art Market 'Underground', BLOOMBERG (June 17, 2019), https://www.bloomberg.com/news/articles/2019-06-17/billionaire-s-dealfor-sotheby-s-pushes-art-market-underground [https://perma.cc/JC4J-MAKE].

75. Hill, supra note 18, at 979.

76. See, e.g., Abha Bhattarai, 'A Tipping Point in Fast Fashion': Forever 21's Bankruptcy Signals the Shifting Priorities of Young Shoppers, WASH. Post (Oct. 3, 2019), https://www.washingtonpost.com/business/2019/10/03/tipping-point-fast-fashion-forever-s-bankruptcysignals-shifting-priorities-young-shoppers [https://perma.cc/Y9LJ-3NP9]; Abha Bhattarai, Walmart Bought Bonobos - And the Bros Aren't Happy, WASH. Post (May 25, 2018), https://www.washingtonpost.com/business/economy/walmart-bought-bonobos--and-the-bros-arenthappy/2018/05/25/6e4713ac-5aa5-11e8-8836-a4a123c359ab_story.html [https://perma.cc/6J8U-Q6X3]; see also Paula J. Dalley, The Use and Misuse of Disclosure as a Regulatory System, 34 FLA. ST. U.L. Rev. 1089, 1123 (2007); Douglas A. Kysar, Preferences for Process: the Process/Product Distinction and the Regulation of Consumer Choice, 118 HARV. L. REV. 525, 584-87 (2004) (describing the history of consumer activism in the United States).

77. David Vogel, The Market for Virtue: The Potential and Limits of Corporate SOCIAL RESPONSIBILITY 46-52 (2005). For example, several companies pulled their advertising from controversial programs like The Laura Ingraham Show and Tucker Carlson Tonight in response to public pressure. See Oliver Darcy, Tucker Carlson's Show Has Been Hit by an Advertiser Boycott, and It's Having a Visible Effect, CNN (Dec. 20, 2018), https://www.cnn.com/2018/12/20/media/tuckercarlson-fox-news-ad-boycott/index.html [https://perma.cc/9NN8-S9LA]; Jason Schwartz, Big Advertisers Still Shunning Ingraham's Fox News Show Months After Boycotts, Politico (Oct. 16, 2018), https://www.politico.com/story/2018/10/16/ingraham-fox-news-advertising-902466 [https://perma.cc/ZWZ6-MHER]. Financial institutions have also ceased financing gun manufacturers and the private prison industry in response to protest. See, e.g., Laura J. Keller \& Polly Mosendz, BofA Will Stop Lending to Makers of Assault-Style Guns, BloomBerg (Apr. 10, 2018), https://www.bloomberg.com/news/articles/2018-04-10/bofa-will-no-longer-lend-to-some-gunmakersvice-chairman-says [https://perma.cc/9CNJ-XYS2]; Taylor Telford \& Renae Merle, Bank of America Cuts Business Ties with Detention Centers, Private Prisons, WASH. Post (June 27, 2019), https://www.washingtonpost.com/business/2019/06/27/bank-america-cuts-business-ties-with-detentioncenters-private-prisons [https://perma.cc/6RAD-VB8Z].

78. Hill, supra note 2, at 1202, 1208-11.

79. Frank Li et al., Corporate Visibility in Print Media and Corporate Social Responsibility, SUSTAINABILITY (2018). 
Technology makes it easier for reports about bad behavior to spread, and today there even exist apps and other tools to allow consumers to investigate brands' social performance at the point of sale. ${ }^{80}$ In today's polarized political environment, consumers may be especially attentive to brands' social performance; certainly, several companies have made that bet, explicitly tying their brands to controversial political stances. ${ }^{81}$

Perhaps the biggest weakness in these kinds of shaming campaigns is that they are only likely to affect consumer-facing businesses; organizations that do not deal directly with consumers are less likely to feel the same pressure. ${ }^{82}$ That slack may be picked up, however, in the form of employee protest. Since the financial crisis, for example, investment banks have had more trouble attracting new graduates, apparently because the banks' reputations for irresponsibility and lack of social conscience have made them less attractive prospects. ${ }^{83}$ More recently, Facebook's scandals have dimmed its luster in the eyes of newly minted engineers and computer scientists. ${ }^{84}$

80. Kysar, supra note 76, at 582-83; Rebecca Bratek, Smartphone App Reveals the Politics in Your Shopping Cart, L.A. TIMES (Aug. 25, 2014), https://www.latimes.com/nation/la-na-buy-partisan20140825-story.html [https://perma.cc/BX8Y-ZAM4]; Megan Friedman, How a Twitter Boycott Contributed to the Demise of the Ivanka Trump Brand, Elle (July 24, 2018), https://www.elle.com/culture/career-politics/a22539627/grab-your-wallet-boycott-ivanka-trump-brand [https://perma.cc/BP9H-KVBL].

81. Josh Barro, Here's Why More Brands, Like Nike with Colin Kaepernick, Are Openly Liberal, BUS. INSIDER (Sept. 4, 2018), https://www.businessinsider.com/nike-colin-kaepernick-adbrands-more-liberal-2018-9 [https://perma.cc/4FHV-65A6]; David Gelles, CEO Activism Has Become the New Normal, N.Y. TIMES (July 25, 2018), https://www.nytimes.com/2018/07/25/business/dealbook/ceo-activism-study.html [https://perma.cc/DK54-UFGV].

82. VOGEL, supra note 77, at 53. There are some exceptions; for example, corporate clients of elite law firms have begun to "boycott," after a fashion, firms that are insufficiently diverse. See Noam Scheiber \& John Eligon, Elite Law Firm's All-White Partner Class Stirs Debate on Diversity, N.Y. TiMES (Jan. 27, 2019), https://www.nytimes.com/2019/01/27/us/paul-weiss-partner-diversity-lawfirm.html [https://perma.cc/WZA4-2FQ7].

83. Nathaniel Meyersohn, After the Crisis, Silicon Valley Overtook Wall Street as the Place to $B e$, CNN (June 7, 2018), https://money.cnn.com/2018/06/07/news/economy/wall-street-silicon-valleygoogle-goldman-sachs/index.html [https://perma.cc/AR4E-UBEL]; Laura Noonan et al., Beyond Banking: Filling the Recruitment Abyss, FIN. TIMES (Nov. 11, 2015), https://www.ft.com/content/f5f79cfc-8228-11e5-a01c-8650859a4767 [https://perma.cc/U7QP-LQF6]; Laurent Ortmans, Jobs in Banking and Finance Lose Allure, Fin. TIMES (Nov. 1, 2015), https://www.ft.com/content/80f30276-7bd3-11e5-al fe-567b37f80b64 [https://perma.cc/82P5-3E6M].

84. Nellie Bowles, 'I Don't Really Want to Work for Facebook.' So Say Some Computer Science Students, N.Y. TIMES (Nov. 15, 2018), https://www.nytimes.com/2018/11/15/technology/jobsfacebook-computer-science-students.html [https://perma.cc/7DAK-K77L]; Lucie Greene, Big Tech May Be Losing Its Allure for Talented Staff, Fin. TIMES (Aug. 25, 2019), https://www.ft.com/content/5e8affac-c299-11e9-ae6e-a26d1d0455f4 [https://perma.cc/9Z3S-EUKW]; Salvador Rodriguez, Facebook Has Struggled to Hire Talent Since the Cambridge Analytica Scandal, According to Recruiters Who Worked There, CNBC (May 16, 2019), https://www.cnbc.com/2019/05/16/facebook-has-struggled-to-recruit-since-cambridge-analyticascandal.html [https://perma.cc/8RPG-FCEV]; see also Elizabeth Dwoskin \& Todd C. Frankel, The Big Problem for Uber Now: Attracting Talent, WASH. POST (June 14, 2017), https://www.washingtonpost.com/business/economy/the-big-problem-for-uber-now-attractingtalent/2017/06/14/6be22812-4f80-11e7-b064-828ba60fbb98_story.html] [https://perma.cc/BAR2CMG2] (documenting similar problems at Uber). 
The movement extends beyond new hires. Existing employees at a number of companies have recently agitated for their employers to attend more carefully to the social implications of their work. At Google, Microsoft, and Amazon, employees have revolted against projects that raise privacy concerns. ${ }^{85}$ Demonstrating the power of employee protest to reach beyond consumer-facing industries, employees forced the consulting firm McKinsey to cancel a contract with Immigration and Customs Enforcement (ICE). ${ }^{86}$ Wayfair employees staged a walkout over the company's sales to immigrant detention centers. ${ }^{87}$

The fundamental point is that consumers and employees have both the desire, and the ability, to shape corporate behavior to comply with prevailing norms of social responsibility, but this cannot be accomplished without information. Though employees, specifically, may have special insight into corporate initiatives even without public disclosure, they may be bound by nondisclosure agreements, ${ }^{88}$ or have only a vague idea how a small assignment fits into a larger project. ${ }^{89}$ Public disclosure about lines of business, significant

85. Kate Conger \& Cade Metz, Tech Workers Now Want to Know: What Are We Building This For?, N.Y. TIMES (Oct. 7, 2018), https://www.nytimes.com/2018/10/07/technology/tech-workersask-censorship-surveillance.html [https://perma.cc/6W2K-UVFL]; Kelsey Gee, The New Labor Movement: Pushing Employers to Be Socially Active, WALL St. J. (June 25, 2019), https://www.wsj.com/articles/the-new-labor-movement-pushing-employers-to-be-socially-active-

11561476199 [https://perma.cc/B8NR-A6BP]. Employees also persuaded Microsoft to suspend and review its political donation program. See Billy Nauman et al., BlackRock Under Fire, (Dual) Class War, PAC Attack, Fin. Times (Aug. 7, 2019), https://www.ft.com/content/4ad02fa4-b895-11e9-8a88aa6628ac896c [https://perma.cc/47ZR-Q75D].

86. Michael Forsythe \& Walt Bogdanich, McKinsey Ends Work With ICE Amid Furor Over

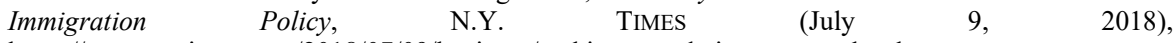
https://www.nytimes.com/2018/07/09/business/mckinsey-ends-ice-contract.html

[https://perma.cc/46CC-FQLF]. Deloitte and GitHub employees have also urged that their employers end relationships with ICE. Gee, supra note 85; Nitasha Tiku, Employees ask GitHub to Cancel ICE Contract: 'We Cannot Offset Human Lives with Money,' WASH. Post (Oct. 9, 2019), https://www.washingtonpost.com/technology/2019/10/09/employees-ask-github-cancel-ice-contract-wecannot-offset-human-lives-with-money [https://perma.cc/DD9A-UDCX].

87. Abha Bhattarai, 'A Cage Is Not a Home': Hundreds of Wayfair Employees Walk Out to Protest Sales to Migrant Detention Center, WAsh. Post (June 26, 2019), https://www.washingtonpost.com/business/2019/06/26/cage-is-not-home-hundreds-wayfair-employeeswalk-out-protest-sales-migrant-detention-center [https://perma.cc/2TNM-Z7AM]. Slack engineers agreed not to build tools that can be used to target immigrants. Cameron Bird et al., The Tech Revolt, CALIF. SUNDAY MAG. (Jan. 23, 2019), https://story.californiasunday.com/tech-revolt [https://perma.cc/B94U-7D2Y].

88. Cf. Jay Greene, Amazon Employees Launch Mass Defiance of Company Communications Policy in Support of Colleagues, WASH. Post (Jan. 27, 2020), https://www.washingtonpost.com/technology/2020/01/26/amazon-employees-plan-mass-defiancecompany-communications-policy-support-colleagues [https://perma.cc/GP3D-6WFK] (describing Amazon's policy of prohibiting employees from publicly commenting on Amazon's social performance; concerns may be raised internally but discussions must be kept confidential).

89. Cf. Noam Scheiber \& Kate Conger, The Great Google Revolt, N.Y. Times (Feb. 18, 2020), https://www.nytimes.com/interactive/2020/02/18/magazine/google-revolt.html [https://perma.cc/9XPJ-3U5K] (reporting that Google has tried to prevent internal dissension by concealing controversial projects from all but "need to know" employees). 
customers, and contracting partners may provide both groups with valuable information they can use to gain a fuller picture of corporate behavior. ${ }^{90}$

Finally, corporate disclosure can assist citizen activism in the most basic of ways: political participation. Corporate expenditures on political advertisements and lobbying may be intended to sway voters; more information both about corporate political spending, and about their lines of business (i.e., their financial interests in matters subject to dispute) will help voters place these efforts in context, contributing to a more informed citizenry that is better able to protect its interests. ${ }^{91}$ Moreover, there are any number of governmental actors who may have close ties to private businesses that are difficult to identify; a system of corporate disclosure can reveal these relationships so that citizens can recognize potential conflicts and, if appropriate, agitate for change. ${ }^{92} \mathrm{ICE}$, for example, refuses to provide details of the amounts it pays to private contractors to detain migrants. Journalists have deduced some details by relying in part on the disclosures of public companies, ${ }^{93}$ but there are any number of privately held companies that provide detention-related services and operate out of the public eye. ${ }^{94}$ A system of public disclosure would make it easier for citizens to hold not only corporations, but their congressional representatives, accountable, rendering the formal regulatory system more effective. Indeed, the Supreme Court predicated its support for corporate free speech rights on the existence of such disclosure, ${ }^{95}$ with Justice Kennedy later

90. Estlund, supra note 69, at 378-79 (disclosure to employees will help them select jobs on the basis of social performance). As in the context of regulation, see Section I.B.3, infra, the public may be aided by journalists or other experts in interpreting these disclosures.

91. Sarah Haan, Voter Primacy, 83 FordHAM L. ReV. 2655, 2682-83 (2015).

92. Benjamin P. Edwards, The Dark Side of Self-Regulation, 85 U. CIN. L. REV. 573, 587-91, 616-20 (2017) (describing industry ties of FINRA's Board of Governors; highlighting that a lack of corporate disclosure may make these difficult to detect).

93. Spencer Ackerman \& Adam Rawnsley, $\$ 800$ Million in Taxpayer Money Went to Private Prisons Where Migrants Work for Pennies, THE DAILY BEAST (Dec. 27, 2018), https://www.thedailybeast.com/dollar800-million-in-taxpayer-money-went-to-private-prisons-wheremigrants-work-for-pennies [https://perma.cc/8Y96-2SVT].

94. Yuki Noguchi, 'No Meaningful Oversight': ICE Contractor Overlooked Problems At Detention Centers, NPR (July 17, 2019), https://www.npr.org/2019/07/17/741181529/no-meaningfuloversight-ice-contractor-overlooked-problems-at-detention-centers [https://perma.cc/3Z3E-K3Y4] (reporting on flawed inspection services provided by a privately held company); Dan Primack, Pro Rata, AxIOS (June 27, 2019), https://www.axios.com/newsletters/axios-pro-rata-58ccc2ab-b4ff-406e8a37-9eb2d52f971d.html [https://perma.cc/J8LZ-WEJY] (describing one private prison company that canceled an IPO due to political controversy); PRIVATE EQUITY STAKeHOLDER PROJECT, Fact Sheet: Private Equity-Owned Firms Dominate Prison and Detention Services (Sept. 17, 2018), https://pestakeholder.org/report/private-equity-owned-firms-dominate-prison-and-detention-services/ [https://perma.cc/YK4D-K8C7].

95. Citizens United v. FEC, 558 U.S. 310, 370 (2010) ("With the advent of the Internet, prompt disclosure of expenditures can provide shareholders and citizens with the information needed to hold corporations and elected officials accountable for their positions and supporters. . . [C]itizens can see whether elected officials are 'in the pocket' of so-called moneyed interests."). 
admitting that the real-world disclosure system is "not working the way it should." 96

\section{Legal Compliance and Lawmaking}

Transparency can also make regulation more effective, both by improving the informational environment in which lawmakers operate and by permitting the public to participate in the regulatory process. Today, regulators rely on the generalized disclosure obligations imposed by the securities laws to engage in economic planning, identify potential legal violations, and deter companies from violating the law in the first place. ${ }^{97}$ Holistic disclosures, designed with regulatory needs in mind, would only improve these functions.

Consider the example of Airbnb, a privately held company that is not subject to mandatory reporting under the federal securities laws. It offers more rooms than many of the largest hotel companies in the world, and yet regulators know very little about its internal operations. ${ }^{98}$ As a result, they are so hungry for data about Airbnb's activities that they purchase it from a single hobbyist who works from home culling information from Airbnb's website. ${ }^{99}$

Airbnb is not an isolated case. Corporations often provide critical infrastructure such as rail services, ${ }^{100}$ water and sewerage, ${ }^{101}$ and medical care, ${ }^{102}$ through opaque private equity firms. That opacity lends itself to abuse: Once these services are privatized, there are often disputes over rates and quality of service. ${ }^{103}$ After private equity firms began providing ambulance and firefighting services, for example, there were complaints not only about overbilling, but also depleted medical supplies and slow response times. ${ }^{104}$

\footnotetext{
96. Paul Blumenthal, Anthony Kennedy's Citizens United Disclosure Salve 'Not Working,' HufFPost (Nov. 2, 2015), https://www.huffpost.com/entry/citizens-united-anthonykennedy_n_5637c481e4b0631799134b92 [https://perma.cc/TT4V-JD99].

97. See Section I.A, supra.

98. Fan, supra note 6, at 601.

99. Olivia Carville, Meet Murray Cox, The Man Trying to Take Down Airbnb, BloomBerg (May 23, 2019), https://www.bloomberg.com/news/articles/2019-05-23/meet-murray-cox-airbnb-spublic-enemy-no-1-in-new-york [https://perma.cc/X76E-4DQY].

100. Ben Protess et al., How Private Equity Found Power and Profit in State Capitols, N.Y. TIMES (July 14, 2016), https://www.nytimes.com/2016/07/15/business/dealbook/private-equityinfluence-fortress-investment-group.html [https://perma.cc/AW9T-J3UN].

101. Danielle Ivory et al., In American Towns, Private Profits From Public Works, N.Y. TIMES (Dec. 24, 2016), https://www.nytimes.com/2016/12/24/business/dealbook/private-equitywater.html [https://perma.cc/YW7B-PFAQ].

102. Danielle Ivory et al., When You Dial 911 and Wall Street Answers, N.Y. TimEs (June 25, 2016), https://www.nytimes.com/2016/06/26/business/dealbook/when-you-dial-911-and-wall-streetanswers.html [https://perma.cc/222X-XCR4].

103. Ivory et al., supra note 101; Ivory et al., supra note 102.

104. Ivory et al., supra note 102 . Recently, there have been accusations that a private equity firm intentionally drove a hospital into bankruptcy in order to profit from the land. Lydia DePillis, Rich Investors May Have Let a Hospital Go Bankrupt. Now, They Could Profit from the Land, CNN (July 29, 2019), https://www.cnn.com/2019/07/29/economy/hahnemann-hospital-closing-philadelphia/index.html [https://perma.cc/V7VV-FTP4]. Complaints have reached the point where Congress has recently opened a bipartisan investigation into billing practices of private equity backed healthcare groups. See Chris
} 
Many private equity firms own rental housing, or control mortgages, in large swaths of the country, where their aggressive tactics result in evictions, foreclosures, and homelessness. ${ }^{105}$ But efforts by local officials to enforce basic housing codes are often frustrated by an inability to even identify the individuals responsible for upkeep of the property. ${ }^{106}$ If these companies filed regular public disclosures with basic information about their operations, including their lines of business and history of legal disputes, governments might be able to develop and enforce more effective schemes of regulation. Localities would detect trends much faster, and be in a position to address potential problems before they arise.

To be sure, regulators can and do require companies to disclose information to them directly, without making it available to the general public. But these fractured efforts could almost certainly benefit from a cooperatively designed disclosure package, available to everyone, for the same reason that it is inefficient to require investors to individually negotiate with companies for specific types of information. ${ }^{107}$ There are multiple federal agencies and countless local regulators, all with different budgets and levels of resources to devote to data collection. They may find it difficult—or even illegal - to coordinate with each other to develop a holistic view of particular companies or economic systems. Many are specialized, which on the one hand means they may not require generalized data, but on the other means they may not know what they do not know; ${ }^{108}$ a set of baseline disclosures may educate them sufficiently to make further requests for information more effective.

Moreover, a public disclosure system improves regulation by allowing private actors to assist regulatory efforts. At the most basic level, public disclosure helps expose false reporting: If companies disclose publicly the information that they falsely report privately, persons with knowledge of the

Flood, US Congress Examines Private Equity Role in Surging Healthcare Costs, Fin. TIMES (Oct. 13, 2019), https://www.ft.com/content/7c8b4d01-flcc-3db2-8b65-589cf4c1d77f [https://perma.cc/N65XYMQK].

105. Ryan Dezember, A Hedge Fund Makes Billions Off Americans' Underwater Mortgages, WALL ST. J. (Dec. 25, 2018), https://www.wsj.com/articles/a-hedge-fund-makes-billions-off-americansunderwater-mortgages-11545742800 [https://perma.cc/U76L-TZM7]; Todd C. Frankel \& Dan Keating, Eviction Filings and Code Complaints: What Happened When a Private Equity Firm Became One City's Biggest Homeowner, WASH. Post (Dec. 25, 2018), https://www.washingtonpost.com/business/economy/eviction-filings-and-code-complaints-whathappened-when-a-private-equity-firm-became-one-citys-biggest-homeowner/2018/12/25/995678d402f3-11e9-b6a9-0aa5c2fcc9e4_story.html [https://perma.cc/2FD4-UWGN]; Rachel Monroe, Gone Baby Gone, NEW REPUBLIC (Sept. 19, 2017), https://newrepublic.com/article/144528/gone-baby-gone-wakehousing-crisis-new-breed-real-estate-investor-destroying-america-cities [https://perma.cc/U3HL-FL2Y]; Joshua Schneyer \& Andrea Januta, As U.S. Soldiers Battle Landlord, Confidential Records Shine Light on His Lucrative Business, REUTERS (Dec. 27, 2018), https://www.reuters.com/investigates/specialreport/usa-military-developer [https://perma.cc/4Y3B-9SUX]

106. Frankel \& Keating, supra note 105 (quoting a City Council Member: "It's just become a nightmare ... . If I have a code violation, you can't even find a person to get on the phone.”).

107. See infra Part V.

108. Cf. Shapira \& Zingales, supra note 23 . 
truth may spot irregularities and blow the whistle. ${ }^{109}$ Additionally, many regulatory systems rely in part on private enforcement, but litigants may have difficulty gathering information or recognizing that a problem is systemic in nature. Public disclosures make it easier for attorneys to identify violations and tort victims, and for those victims to share information and coordinate with each other. ${ }^{110}$ Lawsuits by private plaintiffs may then provide a further source of information to regulators in aid of their own enforcement of the law, or in aid of further lawmaking. ${ }^{111}$ Experts, academics, and journalists can analyze public disclosures, and their work can then be relied upon by regulators to identify legal violations or areas in need of additional regulation.

Finally, public disclosure can inspire community organization and protest. This may have an independent disciplining effect, as discussed above, but communities may also pressure otherwise reluctant lawmakers to take action against practices that harm the public. ${ }^{12}$

\section{Investors Versus the Public}

In the current regulatory framework, the only path to obtain holistic corporate disclosure runs through the federal securities laws. This regime is dysfunctional because the investor audience has different informational needs than an audience of the general public.

\section{A. Different Companies}

Perhaps most fundamentally, investors and the broader society need information about different companies. Securities disclosures are required when a business raises capital from the public, defined as a dispersed set of investors with different levels of sophistication. Under such circumstances, each investor might otherwise have to engage in costly and duplicative efforts to obtain information necessary to value the issuer's securities, and the dispersion and heterogeneity of the investor pool would create collective action problems preventing investors from bargaining for information as a group. ${ }^{113}$ By contrast, the noninvesting public requires information about companies that engage in enough economic activity to affect wide segments of society, ${ }^{114}$ regardless of their method of financing. hazards).

109. Cf. Estlund, supra note 69 , at 375 (raising that possibility in the context of workplace

110. Joshua D. Blank, Reconsidering Corporate Tax Privacy, 11 N.Y.U. J. L. \& BuS. 31, 49 (2014) (disclosure of corporate tax information); Estlund, supra note 69, at 373-74 (disclosure of workplace violations).

111. See Alexandra D. Lahav, The Roles of Litigation in American Democracy, 65 EMORY L.J. 1657 (2016) (discovery generated in private litigation can be used to aid regulators).

112. Blank, supra note 110, at 80 (making this argument in the context of disclosure of tax information); Sale, New Public, supra note 59, at 144.

113. Langevoort \& Thompson, supra note 5, at 364 .

114. Id. at 342 . 
Once upon a time, the two categories may have been tolerably similar; because there were few options for businesses to raise capital privately, mostthough not all ${ }^{115}$ — companies with a broad societal impact were likely to also be public for securities law purposes. However, in recent years, opportunities for raising capital in private markets have expanded, and thus there is a growing divergence between companies that are defined as public under the securities laws, and companies that are sufficiently large and impactful that the general public may have a legitimate need for disclosure about their operations. ${ }^{116}$

The transformation has come in response to changes to investors themselves. Whereas once most investors were retail investors-ordinary persons - by 1980 , about $40 \%$ of all U.S. corporate equities were held by institutions such as mutual funds and pension funds, ${ }^{117}$ and today that figure is closer to 70 or $80 \% .{ }^{118}$ The result is a wealthier, more sophisticated, and more powerful pool of investors that both Congress and the SEC have judged to be less in need of securities law protection. Thus, both by statute and regulation, the securities laws have been loosened to allow companies more opportunities to seek funding from wealthy investors while avoiding mandatory disclosure obligations. ${ }^{119}$ This has been accomplished in a variety of ways, but in general, the law has made it easier for companies to sell securities to certain investors while still treating the sales as "private" rather than "public," allowing them to avoid federal disclosure requirements. ${ }^{120}$ The Exchange Act has also been amended to broaden the number of security holders necessary to trigger public company status. ${ }^{121}$ Under this new regime, companies can raise vast amounts of capital, and develop sprawling international operations, without public SEC filings. ${ }^{122}$

115. Many of the largest companies in the United States are privately held and go back decades. See Burwell v. Hobby Lobby Stores, Inc., 573 U.S. 682, 757 n.19 (2014) (Ginsburg, J., dissenting).

116. Additionally, some companies that have issued securities to the public may still be too small to have much societal relevance. See Langevoort \& Thompson, supra note 5, at 342.

117. Gordon, supra note 13, at 1521-22.

118. Amy Westbrook \& David A. Westbrook, Unicorns, Guardians, and the Concentration of the U.S. Equity Markets, 96 NEB. L. REV. 688, 729-30 (2018).

119. Elisabeth de Fontenay, The Deregulation of Private Capital and the Decline of the Public Company, 68 HASTINGS L.J. 445, 467-49 (2017); Jones, supra note 60, at 174-77; Elizabeth Pollman, Information Issues on Wall Street 2.0, 161 U. PA. L. REV. 179, 206-08 (2012).

120. Fontenay, supra note 119119, at 467-69; Jones, supra note 60, at 176; see also Janet D. Lowder, Rule 701 Additional Disclosure Threshold Raised to \$10M, NAT. L. REv. (July 27, 2018), https://www.natlawreview.com/article/rule-701-additional-disclosure-threshold-raised-to-10m-secsolicits-comments-to [https://perma.cc/FCT4-HZ62] (describing easing of rules for issuing stock compensation to employees).

121. Jones, supra note 60, at 177.

122. Congress and the SEC have also facilitated private capital raising by making it easier for holders of private company securities to trade amongst themselves. See Fontenay, supra note 119, at 470-72; Jones, supra note 60, at 174; see also Nicolas Grabar, FAST Act Amendments to the U.S. Securities Laws, Harv. L. Sch. F. ON CORP. Governance \& Fin. Reg. (Jan. 16, 2016), https://corpgov.law.harvard.edu/2016/01/16/fast-act-amendments-to-the-u-s-securities-laws 
Uber presents a classic example. Founded in 2009, it did not offer its securities to the public for ten years, by which time it had swollen to a valuation of $\$ 82$ billion. ${ }^{123}$ By the time of its public offering, it was one of the country's most recognized brands, operating in sixty-three countries with over 22,000 employees (not counting drivers). ${ }^{124}$ It also developed an unusually pugnacious relationship with regulators, resulting in numerous scandals around the globe. ${ }^{125}$ Eventually, an internal investigation revealed a work culture involving on-the-job drinking, drug use, and blatant sexual harassment and sexual discrimination. ${ }^{126}$ Yet had the company not remained private for so long, it is unlikely Uber's toxic work environment could have persisted, or grown to the proportions it eventually reached; ${ }^{127}$ indeed, serious reform efforts were undertaken as part of Uber's preparation for an IPO. ${ }^{128}$ This is because, as a public company, Uber would have had to disclose its sources of income and risks to its operations, including legal risks. ${ }^{129}$ At the same time, its Board of Directors would have had to sign off on any disclosures Uber made, necessitating that information about its internal operations be brought to its attention. Caught between the unpleasant choices of publicly announcing

[https://perma.cc/NHH6-C6YX] (describing statutory amendments that expand opportunities for trading private stock).

123. Michael J. de la Merced \& Kate Conger, Uber I.P.O. Values Ride-Hailing Giant at $\$ 82.4$ Billion, N.Y. TIMES (May 9, 2019), https://www.nytimes.com/2019/05/09/technology/uber-ipo-stockprice.html [https://perma.cc/9XHW-283T].

124. Uber, Registration Statement (Form S-1) (Apr. 26, 2019), https://www.sec.gov/Archives/edgar/data/1543151/000119312519120759/d647752ds1a.htm [https://perma.cc/LT4D-3663].

125. Jones, supra note 60, at 181; Megan Rose Dickey, Uber Fined \$7.6 Million In California, TECHCRUNCH (Jan. 14, 2016), https://techcrunch.com/2016/01/14/uber-fined-7-6-million-incalifornia [https://perma.cc/KUT4-MJLX]; Mike Isaac, How Uber Deceives the Authorities Worldwide, N.Y. Times (Mar. 3, 2017), https://www.nytimes.com/2017/03/03/technology/uber-greyball-programevade-authorities.html [https://perma.cc/ZUX5-TLLU]; Mike Isaac, Uber Is Sued by Woman Who Was Raped by One of Its Drivers in India, N.Y. TIMES (June 15, 2017), https://www.nytimes.com/2017/06/15/technology/uber-india-rape-lawsuit.html [https://perma.cc/6F27QFWB]; Ben Smith, Uber Executive Suggests Digging Up Dirt On Journalists, BuZzFeEd (Nov. 17, 2014), https://www.buzzfeednews.com/article/bensmith/uber-executive-suggests-digging-up-dirt-onjournalists [https://perma.cc/2S5X-F4TJ]; Uber CEO Kalanick Took Workers to an 'Escort-Karaoke' Bar, N.Y. POST (Mar. 27, 2017), https://nypost.com/2017/03/27/uber-ceo-kalanick-took-workers-to-anescort-karaoke-bar [https://perma.cc/WQ9M-NRS2]

126. Yoree Koh, Uber's Party Is Over: New Curbs on Alcohol, Office Flings, Wall ST. J. (June 13, 2017), https://www.wsj.com/articles/ubers-party-is-over-new-curbs-on-alcohol-office-flings1497394763 [https://perma.cc/6CPY-ZYTK]; Maya Kosoff, Mass Firings at Uber as Sexual Harassment Scandal Grows, VANITY FAIR (June 6, 2017), https://www.vanityfair.com/news/2017/06/uber-fires-20-employees-harassment-investigation [https://perma.cc/9AV4-2T2V].

127. Jones, supra note 60, at 166-68.

128. Peter Blumberg \& Robert Burnson, Uber Aims to Shed Troubled Past in Pre-IPO PeaceMaking Bonanza, BLOOMBERG (Dec. 15, 2018), https://www.bloomberg.com/news/articles/2018-1215/uber-aims-to-shed-troubled-past-in-pre-ipo-peace-making-bonanza [https://perma.cc/W5B8-CQ42].

129. 17 C.F.R. $§ 229.105$ (2019); see also Div. OF CoRP. Fin., U.S. SEC. \& EXCH. COMM’N, StAFF Report on CORPORATE ACCOUNTABILITY: A Re-Examination OF RUles RElating to Shareholder COMMUNiCATIONS, Shareholder Participation IN THE CORPORATE Electoral Process AND Corporate GovernanCE GeNerally 286-87 (1980) (printed for the use of S. Comm. on Banking, Housing, and Urban Affairs, 96th Cong., 2d Sess.) [hereinafter Staff Report]. 
Uber's violations of the law and systemically unstable culture, or risking personal liability for false statements, board members would have been incentivized to ensure that any deficiencies were corrected. ${ }^{130}$

Significantly, when Uber's legal problems spilled into the public eye, so did its governance structure, generating an unprecedented level of public attention to its board composition and the voting power of its stock ${ }^{131}$ typically the core objects of securities disclosure. ${ }^{132}$ Yet Uber remained "private" because its investors (many of which were wealthy institutions) were deemed too sophisticated to require the securities laws' protection.

Uber may be an extreme case, but it is not the only one; similar problems have infected other large startups, including WeWork, Theranos, Zenefits, and SoFi. ${ }^{133}$ This is not to say that dysfunctional and lawbreaking work cultures cannot develop at public companies (clearly, they can $^{134}$ ) but the secrecy afforded by private status, coupled with the sizes to which these companies can

130. Thompson \& Sale, supra note 50, at 873-74; Jones, supra note 60, at 178.

131. REUTERs, A Challenge to Finding Uber's New COO: Its CEO, FORTune (Apr. 13, 2017), http://fortune.com/2017/04/13/ceo-kalanick-coo-search-culture [https://perma.cc/552L-C7V5]; Greg Bensinger et al., Uber Interviews Heavyweights for a Crucial Job: Handling Travis Kalanick, Fox Bus. (Apr. 27, 2017), https://www.foxbusiness.com/features/uber-interviews-heavyweights-for-acrucial-job-handling-travis-kalanick [https://perma.cc/L5ZA-D7PG]; Mike Isaac, Uber's C.E.O. Plays With Fire, N.Y. Times (Apr. 23, 2017), https://www.nytimes.com/2017/04/23/technology/traviskalanick-pushes-uber-and-himself-to-the-precipice.html [https://perma.cc/5WE7-ZPV3]; Mike Isaac, Uber Embraces Major Reforms as Travis Kalanick, the C.E.O., Steps Away, N.Y. TIMES (June 13, 2017), https://www.nytimes.com/2017/06/13/technology/uber-travis-kalanick-holder-report.html [https://perma.cc/3FG6-UAFH].

132. Similarly, reports of related-party transactions between The Boring Company and SpaceX - normally the stuff of securities disclosure - have been an object of public fascination despite the fact that both companies are privately held. See Rob Copeland, Elon Musk's New Boring Co. Faced Questions Over SpaceX Financial Ties, WALL ST. J. (Dec. 17, 2018), https://www.wsj.com/articles/elon-musks-new-boring-co-faced-questions-over-spacex-financial-ties11545078371 [https://perma.cc/2ARN-K2TV]; WeWork, a private company, attracted attention to its governance structure long before it attempted an initial public offering of its stock. See Eliot Brown, WeWork's CEO Makes Millions as Landlord to WeWork, WALL ST. J. (Jan. 16, 2019), https://www.wsj.com/articles/weworks-ceo-makes-millions-as-landlord-to-wework-11547640000 [https://perma.cc/7K93-NZKH] (related-party transactions at unicorn startup WeWork). The founder/CEO of a private company recently told the New York Times, "I honestly thought that people didn't care that much about the inner workings of [my company] . . . Who is C.E.O. and who is executive chairman - that wasn't something that, at a private company that's less than four years old that sells travel products, I just didn't think would be news and people would care." Andrew Ross Sorkin, Away C.E.O. is Back, Just Weeks After Stepping Down, N.Y. Times (Jan. 13, 2020), https://www.nytimes.com/2020/01/13/business/steph-korey-away.html [https://perma.cc/CF3Y-SB3Y].

133. Jones, supra note60, at 179-82; Nathaniel Popper \& Katie Benner, 'It Was a Frat House': Inside the Sex Scandal That Toppled SoFi's C.E.O., N.Y. TIMES (Sept. 12, 2017), https://www.nytimes.com/2017/09/12/technology/sofi-chief-executive-toxic-workplace.html

[https://perma.cc/7B4K-43CK]; Dana Schuster, Ousted WeWork CEO Adam Neumann is a 'Phony' Who 'Thinks He Is a Jesus Figure': Insiders, N.Y. POST (Sept. 28, 2019), https://nypost.com/2019/09/28/ousted-wework-ceo-adam-neumann-is-a-phony-who-thinks-he-is-ajesus-figure-insiders/amp [https://perma.cc/AFN5-RCWR]; Rolfe Winkler, Zenefits Once Told Employees: No Sex in Stairwells, WALL ST. J. (Feb. 22, 2016), https://www.wsj.com/articles/zenefitsonce-told-employees-no-sex-in-stairwells-1456183097 [https://perma.cc/UJA7-RA4V].

134. See, e.g., Bethany McLean, How Wells Fargo's Cutthroat Corporate Culture Allegedly Drove Bankers to Fraud, VANITY FAIR (May 31, 2017), https://www.vanityfair.com/news/2017/05/wells-fargo-corporate-culture-fraud [https://perma.cc/2MGPQTXS]. 
grow, makes problems more likely to develop and less likely to be addressed, which magnifies the harms they can cause. ${ }^{135}$

Nor is the issue of corporate secrecy confined to startups: It also extends to buyouts of public firms, usually by private equity funds. Once a private equity fund purchases the outstanding public securities of an existing firm, that firm is no longer required to file securities disclosures, and the public no longer has visibility into its operations. ${ }^{136}$ Recent deregulation of these private funds has enabled them to grow to enormous proportions - usually by raising capital from other institutional investors ${ }^{137}$ — which only enables them to seek out more and bigger targets, ${ }^{138}$ taking an ever increasing number of businesses out of the public eye. ${ }^{139}$ Though these companies may eventually return to the public markets, that can take years to accomplish, if it ever occurs. ${ }^{140}$

The sudden withdrawal of large, significant companies from public scrutiny has made more salient the positive externalities associated with securities disclosure. Commentators have lamented everything from the loss of

135. Jones, supra note 60, at 178; Elizabeth Pollman, Startup Governance, 168 U. PA. L. REV. 155, 202-05 (2019) (observing that in startup companies, growth is often prized over compliance, which can encourage lawbreaking, facilitated by the lack of public disclosure). It has long been recognized that smaller public companies present a greater fraud risk than their larger counterparts, in part because the lesser degree of scrutiny afforded these companies makes it harder to detect misconduct. See Stephen J. Choi, Gatekeepers and the Internet: Rethinking the Regulation of Small Business Capital Formation, 2 J. SMall \& EMERGing Bus. L. 27, 29 (1998); Stephen J. Choi, Company Registration: Toward a Status-Based Antifraud Regime, 64 U. CHI. L. REV. 567, 581-82 (1997).

136. Some buyouts are financed with publicly issued bonds, in which case the target firm may remain subject to securities reporting requirements. Robert P. Bartlett, III, Going Private But Staying Public: Reexamining the Effect of Sarbanes-Oxley on Firms' Going-Private Decisions, 76 U. CHI. L. REV. 7, 9 (2009).

This is not always the case, however, see Fontenay, supra note 119 , at 463 , and, especially in recent years, private equity firms have found it easier to finance buyouts with loans that escape federal securities regulation. See Robert Prilmeier \& René M. Stulz, Securities Laws and the Choice Between Loans and Bonds for Highly Levered Firms (Fisher Coll. of Bus. Working Paper No. 2019-03-01, 2019), https://ssrn.com/abstract=3314270 [https://perma.cc/D6XK-Q2KD].

137. See generally Chris Flood, Behold the Giants, the Vast New Buyout Funds of Private Equity, FIN. TIMES (Feb. 17, 2019), https://www.ft.com/content/11257444-b17f-39d6-b006c4e774aa3c0c [https://perma.cc/E5P2-93NU]; Robin Wigglesworth, Private Versus Public Markets Is the Battle to Watch, FIN. TIMES (Feb. 8, 2019), https://www.ft.com/content/7ce1 ee52-2b0e-11e9-88a4c32129756dd8 [https://perma.cc/3BG8-MX4U].

138. Fontenay, supra note 119 , at 467-68. Funds' permission to raise capital privately is conditioned on limiting their investor pool to sophisticated purchasers, defined by wealth. See 15 U.S.C. $\S \S 80 a-3(c)(7), 80 a-2(a)(51)(2018)$.

139. Between 2015 and the first nine months of 2018, 279 public companies in the US and Canada were bought out by private equity firms. See Kevin Dowd, Take-Private Buyouts on Pace for Decade Low in 2018, PITCHBOOK (Sept. 12, 2018), https://pitchbook.com/news/articles/take-privatebuyouts-on-pace-for-decade-low-in-2018 [https://perma.cc/5A6P-EJBR]. Though activity declined in 2018, ironically, this is attributed in part to the declining number of public companies overall; there are fewer targets available, and those that remain are much larger than in prior years. See id. Though recent changes to the tax laws may slow private equity activity, see Adam Lewis, The US PE Industry in 11 Charts, Рітснвоок (July 30, 2018), https://pitchbook.com/news/articles/the-us-pe-industry-in-11-charts [https://perma.cc/68X6-PRC2], the overall issue is unlikely to disappear.

140. See Lewis, supra note 139 (reporting that private equity firms increasingly "exit" their investment by selling to new private equity firms rather than through a public offering). 
public data about companies with significant impact on local economies ${ }^{141}$ to the loss of social control that seems to have encouraged the development of particularly dysfunctional-and lawbreaking - corporate cultures. ${ }^{142}$ Yet despite this broad recognition of the degree to which noninvestor audiences rely on disclosures required by the federal securities laws, few have taken the next step to question the wisdom of relying on the securities disclosure system - rather than a general system of corporate disclosure - to provide these benefits in the first place.

For example, through her concept of "publicness," Hillary Sale has explored the ways that securities disclosures force companies to operate with an awareness of how their actions affect, and are perceived by, the broader community. ${ }^{143}$ Sale describes this as a kind of cycle: Shareholders and managers can generally arrange affairs among themselves, but when managers' actions have broad ramifications for society as a whole, the public demands more insight into their functioning, which is then provided via federal securities regulation. ${ }^{144}$ Sale's thesis thus depends on corporate transparency not only to investor audiences, but to noninvestor audiences as well. ${ }^{145}$ Yet in today's regulatory environment, transparency is required purely by dint of the fact that a company has chosen to make its securities available for general trading. If "publicness" refers to companies whose conduct impacts society, there is no reason why the definition of "public" for the securities laws should be coextensive with a conception of "publicness" that triggers a need for public monitoring.

To put it another way, Sale's "publicness" concept descends from earlier thinkers who argued that corporations have a public quality because of their ability to raise capital from many investors who exert little control over operations. ${ }^{146}$ This definition is generally consonant with the notion that it is the public sale of securities that triggers the need for greater societal scrutiny. However, investing today is accomplished via institutional intermediaries, which allows massive investment from a nominally limited shareholder base, even though ultimately the capital of thousands or hundreds of thousands of natural persons may be involved. The result is that the companies we call "private" for securities law purposes present the same problems of publicness as companies that offer their securities for unrestricted trading. ${ }^{147}$

Commentators frequently elide the distinction between the investorprotection rationale that justifies securities regulation, and the broader social

141. Fan, supra note 6, at 599-602.

142. Jones, supra note 60 , at $179-80$.

143. Hillary A. Sale, Public Governance, 81 GEO. WASH. L. REv. 1012, 1017-32 (2013) [hereinafter Public Governance].

144. Id. at 1013 .

145. Sale, New Public, supra note 59, at 138.

146. See infra Section III.A; see also Adolf A. Berle \& Gardiner C. Means, THE Modern CORPORATION \& PRIVATE PROPERTY 5-7 (1932).

147. This is a point that Adolf Berle recognized. See Bratton \& Wachter, supra note 8, at 148. 
benefits that accrue from the disclosures that follow. Jennifer Fan, for example, has expressed alarm about the trend of allowing more companies to stay private and thus avoid public reporting obligations. ${ }^{148}$ Fan points out that the growth of large nonreporting companies has deprived the public of important sources of economic data, with costs borne by regulators, employees, and society as a whole. ${ }^{149}$ The natural conclusion, then, is that we need a disclosure framework that looks to audiences beyond investors. Instead, Fan argues for an expansion of investor-oriented securities disclosure. ${ }^{150}$

Donald Langevoort and Robert Thompson are among those who have directly confronted the possibility that "public" for the purposes of incurring broader obligations of transparency need not match the definition of "public" for investor-protection purposes. ${ }^{151}$ At the same time, they continue to tether any disclosure obligations to the federal securities laws, operating on the assumption that disclosure for noninvestor purposes is only needed for the very largest companies, and will only accompany the public sale of securities. ${ }^{152}$

What this exercise demonstrates is that commentators have very different intuitions of what defines "publicness" and which companies should be subject to it. While some would reserve "publicness" (i.e, stakeholder-oriented disclosure) to America's biggest publicly traded companies, ${ }^{153}$ Fan focuses on the need for basic data for local economies. ${ }^{154}$ Sale's implicit assumption is that "publicness" attaches when a corporation is in a position to do significant harm to the broader populace. ${ }^{155}$ These competing definitions cannot be reconciled

148. Fan, supra note 6, at 609; see also Jones, supra note 60, at 179.

149. Fan, supra note 6, at 585, 591-602; see also Jones, supra note 60, at 179-82.

150. Fan, supra note 6, at 608-11, 637. Similarly, Robert M. Ackman and Lance Cole argue that corporations should have obligations to constituencies other than shareholders, such as employees and communities, but propose as a solution that corporations be required to disclose political spending to their shareholders alone. See Making Corporate Law More Communitarian, 81 BROOK. L. REV. 895, 998-1002, 1008 (2016); see also Andy Green, Making Capital Markets Work for Workers, Investors, and the Public: ESG Disclosure and Corporate Long-Termism, 69 CASE W. RES. L. REV. 909, 920-21 (2019) (proposing that the securities laws require private companies to publicly disclose information about social performance, but adhering to an investor-centric rationale for disclosure).

151. Langevoort \& Thompson, supra note 5, at 342; see also Onnig H. Dombalagian, Principles for Publicness, 67 FLA. L. REV. 649, 706-08 (2015) (proposing to reserve social disclosures for companies included in appropriate stock indices). But see id. at 682 \& n.157 (questioning whether the SEC can manage social disclosures, and pointing out that some private issuers may leave as large a societal footprint as public issuers). That said, some commenters have raised the possibility of creating alternative disclosure regimes to ensure public accountability. See, e.g., Michael D. Guttentag, Patching a Hole in the JOBS Act: How and Why to Rewrite the Rules That Require Firms to Make Periodic Disclosures, 88 IND. L.J. 151, 194-95 (2013).

152. Langevoort \& Thompson, supra note 5, at 342.

153. Dombalagian, supra note 151, at 706-08; Langevoort \& Thompson, supra note 5, at 375.

154. Fan, supra note 6, at 585, 599-602.

155. Sale, Public Governance, supra note 143, at 1013; Sale, Social License, supra note 20, at 24. Sale's definition has a strong pedigree; it echoes the argument of James Hurst that "The idea . . . that the state . . . should not intervene in affairs merely of private concern assumed that most business was 'private' precisely because ... the market existed to keep oppressive or wasteful practices from reaching such proportions as to make them proper subjects of 'public' attention." JAMES WILLARD HURST, THE LEGITIMACY OF THE BUSINESS CORPORATION IN THE LAW OF THE UNITED STATES 1780-1970, 41-42 (1970). 
until we recognize that because disclosure has critical purposes beyond investor (and even market) protection, a regime in which disclosure is mandated only in response to securities trading is inadequate.

To be sure, there are those who claim that the increasing ability of companies to avoid public disclosure is harmful to investors and capital markets, i.e, the core objects of the securities laws, and that the regulatory retrenchment is simply a miscalculation of the relative benefits and burdens of requiring companies to adopt public status. For example, it has been argued that private capital raises rely on information generated by their public company counterparts, and that as the pool of available information thins, distortions and mispricings will increasingly be felt in the private markets. ${ }^{156}$ It is also argued that many classes of investors - such as employees who are paid with private company stock - are ill-served by the new regime. ${ }^{157}$

That set of arguments, however, speaks to whether Congress and the SEC have misjudged the level of disclosure that is necessary to protect investors. The point here is different. Even if one assumes that investors are sufficiently protected under the new regime, there remains the problem that securities disclosure, though intended to serve investors, has long been relied upon by the general public as a mechanism for understanding the power that corporations wield. And that mechanism is weakening. As the editor of the Financial Times recently put it in a speech on the future of financial journalism, "private companies and markets are, by definition, much more opaque and therefore difficult to report on. Holding these private companies and markets to account will be very hard." 158

\section{B. Different Topics}

The public is also interested in different types of information than investor audiences. Securities disclosures are keyed to the legal concept of "materiality," namely facts about which there is a "substantial likelihood" that the "the reasonable shareholder" would consider them important when making voting or trading decisions. ${ }^{159}$ The SEC has taken the position that such facts are those relevant to "a company's financial condition or results of operations." 160 Though many segments of the public may be interested in these

156. Fontenay, supra note 119 , at 449-51.

157. Fan, supra note 6, at 603-04; Abraham J.B. Cable, Fool's Gold, Equity Compensation \& The Mature Startup, 11 VA. L. \& Bus. REV. 615 (2017).

158. Lionel Barber, Too Big to Fail: FT Editor Lionel Barber on the Future of Financial Journalism, FIN. TIMES (Nov. 23, 2018), https://www.ft.com/content/d2a3e50e-ef07-11e8-89c8d36339d835c0 [https://perma.cc/XS3B-JTF3].

159. TSC Indus., Inc. v. Northway, Inc., 426 U.S. 438, 439 (1976); Basic Inc. v. Levinson, 485 U.S. 224 (1988). Materiality has been described as the "cornerstone" of the securities disclosure system. REPORT OF THE ADVISORY COMMITTEE ON CORPORATE DISClOSURE TO THE SECURITIES AND EXCHANGE COMMISSION (1977).

160. Mary Jo White, Chairwoman, U.S. Sec. \& Exch. Comm'n, Keynote Address at the International Corporate Governance Network Annual Conference: Focusing the Lens of Disclosure to 
matters as well, public interests are broader, and extend to the collateral effects of corporate activity, such as environmental impact, the treatment of labor, political lobbying, compliance with regulations, and the like.

In recent years, a growing number of commentators have opined that when it comes to the social impact of corporate activity, the informational needs of investors and the public are not so far apart. So-called "sustainability" metrics (sometimes called "ESG" or "environmental, social, and governance" factors), it is claimed, are material to investors' evaluation of long-term financial performance because sustainable practices ultimately contribute to, or predict, corporate health. ${ }^{161}$ Corporations may generate goodwill from customers, employees, and surrounding communities if they are perceived as good citizens, which may translate into higher sales, better employee retention, and productive relationships with regulators. ${ }^{162}$ Attention to sustainability matters may also signal that the company is well-run in other respects. ${ }^{163}$ In that way, the claim is that investor and public interests are aligned, so that sustainability disclosure designed for investor audiences will both satisfy public needs, and encourage investors to use their influence to provide the social control that the general public demands. ${ }^{164}$

If all that sounds too good to be true, it probably is. The sticking point is that it is not likely, as an empirical matter, that sustainability practices improve corporate performance across the board. ${ }^{165}$ For example, though meta-analyses

Set the Path Forward on Board Diversity, Non-GAAP, and Sustainability (June 27, 2016); see also Guidance Regarding Disclosure Related to Climate Change, Release Nos. 33-9106; 34-61469 (Feb. 8, 2010) (companies should "focus on material information and eliminate immaterial information that does not promote understanding of registrants' financial condition, liquidity and capital resources, changes in financial condition and results of operations").

161. See, e.g., Daniel C. Esty \& Quentin Karpilow, Harnessing Investor Interest in Sustainability, 36 YALE J. ON REG. 625 (2019); Jill E. Fisch, Making Sustainability Disclosure Sustainable, 107 GEO. L.J. 923 (2019); Virginia Harper Ho, Nonfinancial Risk Disclosure and the Costs of Private Ordering, 55 AM. BUS. L.J. 407 (2018). The ESG Disclosure Simplification Act, introduced in the House of Representatives, would require that the SEC develop a system of ESG reporting for public companies on the basis that ESG metrics are material to investors as a matter of law. See H.R. 4329, 116th Cong. (2019).

162. Barnali Choudhury, Serving Two Masters: Incorporating Social Responsibility into the Corporate Paradigm, 11 U. PA. J. BuS. L. 631, 652 (2009); Virginia Harper Ho, Risk-Related Activism: The Business Case for Monitoring Nonfinancial Risk, 41 J. CORP. L. 647, 670 (2016); see also U.S. SENTENCING GUidelines MANUAL § 8C2.5 (U.S. SENTENCING COMM'N 2018) (gauging organizational criminal culpability by reference to whether the behavior was internally tolerated); U.S. ATTORNEYS' MANUAL 9-28.300 (same).

163. See Max M. Schanzenbach \& Robert H. Sitkoff, Reconciling Fiduciary Duty and Social Conscience: The Law and Economics of ESG Investing by a Trustee, 72 STAN. L. REV. 381, 435 (2020).

164. E.g., Laura E. Deeks, Discourse and Duty: University Endowments, Fiduciary Law, and the Cultural Politics of Fossil Fuel Divestment, 47 ENVTL. L. 335, 346-49 (2017); Green, supra note 150, at 911; Ho, supra note 161, at 439 (2018); Matthew Welch, The Year That Capital Markets Finally Woke Up to Climate Risk, ETHICAL CORP. (Dec. 18, 2018), http://ethicalcorp.com/year-capital-marketsfinally-woke-climate-risk [https://perma.cc/YBS2-MC8E].

165. Fisch, supra note 22, at 646 ("Even if the interests of corporate stakeholders are, in many cases, aligned, sometimes they are not. In at least a subset of corporate decisions, there is a true conflict between the interests of different stakeholders, and a decision that benefits one class of stakeholders will harm another."). 
suggest that some pro-social behavior may positively impact the corporation, the effect may be very small, especially as compared to other determinants of performance. ${ }^{166}$ More complex studies demonstrate that any positive effects of sustainability practices vary depending on the characteristics of the firm and its operating environment. ${ }^{167}$ Specific examples abound: Corporations can be recidivist "bad actors" while still seeing their stock prices rise, ${ }^{168}$ and even the Sustainability Accounting Standards Board, an organization devoted to identifying financially material sustainability metrics, concedes that matters like workforce diversity are economically relevant only to a subset of industries. ${ }^{169}$

This is not to claim that there is no evidence that sustainability practices are relevant to firm value; it is simply to point out that the evidence is varied

166. Christopher Geczy et al., Institutional Investing When Shareholders are Not Supreme, 5 Harv. Bus. L. Rev. 73, 87 (2015); Joshua D. Margolis et al., Does It Pay to Be Good...And Does It Matter? (Mar. 1, 2009) (unpublished article), https://ssrn.com/abstract=1866371 [https://perma.cc/5T7B-5R4Y] (finding "[a]fter thirty-five years of research . . . a mildly positive relationship between corporate social performance and corporate financial performance" that is relatively insignificant when compared to other corporate practices).

167. Edward N.W. Aw et al., A Morality Tale of ESG: Assessing Socially Responsible Investing, 19 J. Wealth Mgmt. 14 (2017); Bonnie Buchanan et al., Corporate social responsibility, firm value, and influential institutional ownership, 52 J. CORP. FIN. 73, 74-75 (2018); Heather R. DixonFowler et al., Beyond "Does it Pay to be Green?" A Meta-Analysis of Moderators of the CEP-CFP Relationship, 112 J. Bus. ETHICS 353 (2013); Chitru S. Fernando et al., Corporate Environmental Policy and Shareholder Value: Following the Smart Money, 52 J. FIn. QuANT. ANALYSIS 2023 (2017); Timothy D. Hubbard, The Role of the Chief Executive Officer in Environmental Decisions, 30 FordHAM ENVTL. L. REV. 13, 16-18 (2018); Henri Servaes \& Ane Tamayo, The Impact of Corporate Social Responsibility on Firm Value: The Role of Customer Awareness, 59 MGMT. SCI. 1045 (2013). Part of the problem is that it is difficult to study the effects of ESG on firm performance; firms tend to engage in more socially responsible behavior when they are already prospering. See Buchanan et al., supra note 167, at 74; Joshua D. Margolis \& James P. Walsh, Misery Loves Company: Rethinking Social Initiatives by Business, 48 ADMIN. SCI. Q. 268, 274 (2003). Moreover, observed results vary greatly depending on research design. Gerlinde Berger-Walliser \& Inara Scott, Redefining Corporate Responsibility in an Era of Globalization and Regulatory Hardening, 55 AM. Bus. L.J. 167, 172 (2018); Marc Orlitzky at al., Corporate Social and Financial Performance: A Meta-analysis, 24 ORG. STUDIES 403 (2003). Compare, e.g., Buchanan et al., supra note 167, at 74, with Karl V. Lins et al., Social Capital, Trust, and Firm Performance: The Value of Corporate Social Responsibility During the Financial Crisis, 72 J. Fin. 1785 (2017).

168. Peter J. Henning, Do Companies Fear the Law? The Signs Say No, N.Y. Times (May 15, 2019), https://www.nytimes.com/2019/05/15/business/dealbook/corporate-misconduct-wells-fargogoldman-sachs.html [https://perma.cc/G2NC-BQYB].

169. See Materiality Map, SustainabiLity AcCounting STANDARds Bd., https://materiality.sasb.org; see also Virginia Harper Ho \& Stephen Kim Park, ESG Disclosure in Comparative Perspective: Optimizing Private Ordering in Public Reporting, 41 U. PA. J. INT'L L. 249, 260-61 (2019) ("the materiality of particular ESG factors to investors varies according to industry sector and requires a firm-specific analysis"). Similarly, Fitch Ratings has concluded that ESG scoring is relevant for the credit ratings of only a subset of companies. See FITCH RATINGS, Fitch Ratings Launches ESG Relevance Scores to Show Impact of ESG on Credit (Jan. 7, 2019), https://www.fitchratings.com/site/pr/10058528 [https://perma.cc/FA9C-BQWM]. Insurers, for example, are impacted by environmental ratings, but little else. See Luke Gallin, Majority of U.S. Non-Life Re/insurers' ESG Risk Level Unlikely to Influence Rating: Fitch, REINSURANCE NEWS (May 16, 2019), https://www.reinsurancene.ws/majority-of-u-s-non-life-re-insurers-esg-risk-level-unlikely-to-influencerating-fitch [https://perma.cc/AW5A-D5GX]. Some companies claim that climate change will actually benefit them. Brad Plumer, Companies See Climate Change Hitting Their Bottom Lines in the Next 5 Years, N.Y. TIMES (June 4, 2019), https://www.nytimes.com/2019/06/04/climate/companies-climatechange-financial-impact.html [https://perma.cc/26D6-AFAH]. 
and contingent, ${ }^{170}$ which creates problems for those who claim that disclosure of sustainability information will benefit investors. It is unclear that even if disclosed, investors can earn higher returns by trading on sustainability information. Any investing strategy can only be profitable if returns exceed the costs of implementation, and aside from the general costs associated with active stock-picking, ${ }^{171}$ sustainability strategies may be especially costly because of the need to interpret complex data. ${ }^{172}$ The fact that so many purported socially responsible funds use increasingly capacious definitions of "responsibility" in search of higher returns demonstrates the inherent difficulty of turning sustainability into a profitable investment strategy. ${ }^{173}$ Indeed, some evidence suggests that even as more information about corporations' social performance becomes available, their stock prices remain unchanged. ${ }^{174}$

Additionally, in many cases, the relevance of sustainability information depends on future legal action, such as the implementation of new regulations, or the enforcement of older ones. Yet not only are such actions difficult to predict, but there is no reason to believe that managers can offer shareholders

170. Buchanan et al., supra note 167, at 73-74; Barnali Choudhury, Social Disclosure, 13 BERKELEY BUS. L.J. 183, 210 (2016); Esty \& Karpilow, supra note 161, at 646; Roberto Garcia-Castro et al., Does Social Performance Really Lead to Financial Performance? Accounting for Endogeneity, 92 J. BuS. ETHICS 107 (2010); Alberta Di Giuli \& Leonard Kostovetsky, Are Red or Blue Companies More Likely to Go Green? Politics and Corporate Social Responsibility, 111 J. FIN. ECON. 158 (2014); Schanzenbach \& Sitkoff, supra note 163, at 436, 441-43; Jan Wouters \& Leen Chanet, Corporate Human Rights Responsibility: A European Perspective, 6 Nw. J. INT'L HuM. RTS. 262 (2008); Michal Barzuza et al., Shareholder Value(s): Index Fund Activism and the New Millennial Corporate Governance, 93 S. CAL. L. REV. (forthcoming 2020) (manuscript at 25-27), https://ssrn.com/abstract=3439516 [https://perma.cc/4N4R-NRFK].

171. Schanzenbach \& Sitkoff, supra note 163, at 439-47.

172. Paul Brest et al., How Investors Can (and Can't) Create Social Value, 44 J. CoRP. L. 205, 224-28 (2018); Michael Capucci, The ESG Integration Paradox, 30 J. APPLIED CORP. Fin. 22 (2018) (discussing difficulties asset managers experience attempting to integrate ESG factors into investment strategies); Deeks, supra note 164, at 416; Emily Chasan, How Pacific Life Lost Its Bet on Socially Minded Millennials, L.A. Times (July 27, 2019), https://www.latimes.com/business/story/201907-26/assignment-pacific-life-lost-the-bet-on-socially-minded-millennials-new-story

[https://perma.cc/A6Z9-JVMJ] (socially responsible investment platform failed in part due to high expenses); Paul A. Griffin et al., Environmental Performance and Analyst Information Processing Costs, 61 J. CORP. FIN. (forthcoming April 2020) (market analysts have difficulty interpreting corporate environmental disclosures); Meaghan Kilroy, Performance, Transparency and Risk Cited as the Biggest Barriers to Sustainable Investing, PENSIONS \& INVESTMENTS (Oct. 11, 2017), https://www.pionline.com/article/20171011/ONLINE/171019980/performance-transparency-and-riskcited-as-the-biggest-barriers-to-sustainable-investing-8212-survey [https://perma.cc/2KDU-EWSF] (institutional investors report cost and measurement difficulties as barriers to sustainable investing).

173. Rachel Evans, How Socially Responsible Investing Lost Its Soul, BLOOMBERG (Dec. 18, 2018), https://www.bloomberg.com/news/articles/2018-12-18/exxon-great-marlboros-awesome-howesg-investing-lost-its-way [https://perma.cc/32CC-FVDB]; Jon Sindreu \& Sarah Kent, Why It's so Hard to Be an Ethical Investor, WALL ST. J. (Sept. 1, 2018), https://www.wsj.com/articles/why-its-so-hard-tobe-an-ethical-investor-1535799601 [https://perma.cc/95UK-Y4AQ]; Dana Brakman Reiser \& Anne Tucker, Buyer Beware: Variation and Opacity in ESG and ESG Index Funds, CARDOZO L. ReV. (forthcoming), https://ssrn.com/abstract=3440768 [https://perma.cc/3UN8-B67J].

174. Rodolphe Durand et al., Do Investors Actually Value Sustainability Indices? Replication, Development, and New Evidence on CSR Visibility, 40 STRATEGIC MGMT. J. 1471 (2019). 
information that is not already available from other sources. ${ }^{175}$ For example, though shareholders frequently request information about likely corporate performance under the international Paris Agreement for reducing greenhouse gas emissions, ${ }^{176}$ countries have thus far failed to live up to their obligations and it is not clear they will ever do so $^{177}$-leaving the associated impact on business highly uncertain. As one observer described it, "[p]ut simply: including carbon emissions as an investment issue is a bet on political action." "178

Even if sustainability disclosures do not benefit investors by providing information sufficient to make an investment decision, they might still provide some benefit if they permit investors to take a greater role in governance by using their voice to pressure corporate managers to adopt more sustainable policies. But if sustainable operations do contribute to stockholder wealth, managers may not need to be prodded into adopting them; the market already provides significant incentives for managers to do whatever is necessary to increase stock prices. ${ }^{179}$ This is why, for example, businesses impacted by climate change (and that are capable of cost-effectively adjusting their business models) have been making preparations for many years. ${ }^{180}$ Additionally, although there may be some matters about which shareholders have unique information they can use to improve managerial decision making, these are unlikely to include the long-term benefits of prosocial practices. ${ }^{181}$

175. Joseph P. Kalt et al., Political, Social, and Environmental Shareholder Resolutions: Do They Create or Destroy Shareholder Value? 3 (May 2018), https://corpgov.law.harvard.edu/wpcontent/uploads/2018/06/ESG-Paper-FINAL_reduced-size-002.pdf [https://perma.cc/WTK6-URM7];

Brest et al., supra note 172, at 227-28.

176. Kalt et al., supra note 175, at 30-31.

177. Chris Mooney, Countries Vowed to Cut Carbon Emissions. They Aren't Even Close to Their Goals, U.N. Report Finds, WASH. POST (Nov. 27, 2018), https://www.washingtonpost.com/energy-environment/2018/11/27/countries-vowed-cut-carbonemissions-they-arent-even-close-their-goals-un-report-finds [https://perma.cc/BZ5S-K6Y4].

178. James Mackintosh, What Could Go Wrong with Climate-Change Investing, WALL ST. J. (Dec. 13, 2018),

https://www.wsj.com/articles/what-could-go-wrong-with-climate-change-investing-11544716801 [https://perma.cc/FA6J-N9UK]; see also Jon Emont, One Man's Money-Draining Bet on Climate Change, WALL ST. J. (Dec. 27, 2018), https://www.wsj.com/articles/one-mans-money-draining-bet-onclimate-change-11545912000 [https://perma.cc/Y6SQ-7MJV].

179. See Sean J. Griffith, Opt-In Stewardship: Toward an Optimal Delegation of Mutual Fund Voting Authority, 98 TEX. L. REV. (forthcoming 2020) (manuscript at 40), https://ssrn.com/abstract=3404298 [https://perma.cc/MV59-W74X].

180. E.g., Erin Brodwin, Chocolate Is on Track to Go Extinct in 40 Years, Bus. INSIDER (Dec. 31, 2017), https://www.businessinsider.com/when-chocolate-extinct-2017-12 [https://perma.cc/6TBLHZ8C]; Bradley Hope \& Nicole Friedman, Climate Change Is Forcing the Insurance Industry to Recalculate, WALL ST. J. (Oct. 2, 2018), https:/www.wsj.com/graphics/climate-change-forcinginsurance-industry-recalculate [https://perma.cc/HUK5-VVQP]; Lisa Palmer, Vineyards Take Action as Climate Change Threatens Wines and Livelihoods, GUARDIAN (Oct. 3, 2013), https://www.theguardian.com/sustainable-business/blog/vineyards-climate-change-threat [https://perma.cc/T43K-PDWC].

181. Robert B. Thompson \& Paul H. Edelman, Corporate Voting, 62 VAND. L. REV. 129, $172-$ 73 (2009); Griffith, supra note 179, at 40. That said, there are some theories as to why corporations may benefit from shareholder pressure. For example, some practices may only add value if adopted industrywide, and shareholders with stakes across multiple companies may provide the necessary mechanism for 
Many investors apparently recognize as much. For example, in 2016, the SEC issued a Concept Release requesting public comment on whether it should require disclosure on topics such as "climate change, resource scarcity, corporate social responsibility, and good corporate citizenship." 182 Institutional investors expressed support for mandatory reporting, but with the qualification that the materiality of these matters was "sector-specific." 183 And though asset manager JANA Partners recently announced (with great fanfare) the launch of a socially activist fund that would generate profits by prodding companies to behave more responsibly, JANA put its plans on indefinite hold when it was unable to raise sufficient capital. ${ }^{184}$ The suggestion, then, is that sustainability's financial relevance is limited.

Thus, while the interests of investors and the general public may overlap when it comes to certain aspects of corporate social performance, they are by no means coextensive, and often the sustainability information sought by advocates goes well beyond what will enhance investors' understanding of a corporation's financial position. ${ }^{185}$ So we are left with a puzzle: Given the weaknesses inherent in the claim that shareholders, seeking greater wealth, will prod corporations into more prosocial behavior, why is there so much agitation around sustainability disclosure?

The movement makes sense if we make explicit the underlying subtext: Sustainability disclosure is not intended to add to corporate wealth, and the intended audience is not, or at least not exclusively, investors. Rather, advocates for social disclosure view corporate power as a matter of public

coordination. See Jim Hawley \& Jon Lukomnik, The Long and Short of It, 41 SEATtLE U. L. REV. 449, 450 (2018).

182. Business and Financial Disclosure Required by Regulation S-K, Release No. 33-10064; 34-77599 (April 16, 2016).

183. Virginia E. Harper Ho, Disclosure Overload? Lessons for Risk Disclosure \& ESG Reporting Reform from the Regulation S-K Concept Release, 65 Villanova L. REV. (forthcoming 2020) (manuscript at 40), https://ssrn.com/abstract=3452457 [https://perma.cc/AGT8-SV9W]. Surveys demonstrate investors' reticence when it comes to the financial relevance of ESG strategies. See, e.g., Melissa Karsh \& Saijel Kishan, Quant Trader Seeks \$1.5 Billion for Climate Change Hedge Fund, BLOOMBERG (Jan. 14, 2020),

https://www.bloomberg.com/news/articles/2020-01-14/quant-trader-seeks-1-5-billion-for-climatechange-hedge-fund [https://perma.cc/56K8-5VGP].

184. Leslie P. Norton, Activist Investor That Pressured Apple Delays Launch of New Fund, BARRON's (June 6, 2019), https://www.barrons.com/articles/jana-partners-activist-investor-fund51559837142 [https://perma.cc/HF4B-JU6S]. Investors have also pulled back from sustainability commitments because of the difficulties in earning a satisfactory return. See, e.g., Kevin Allison, Calpers Rethinking Policy Banning Investment in Tobacco Stocks, N.Y. TimES (Apr. 5, 2016), https://www.nytimes.com/2016/04/06/business/dealbook/calpers-rethinking-policy-banning-investmentin-tobacco-stocks.html [https://perma.cc/Y2A7-2VJD]; Heather Gillers, Calpers' Dilemma: Save the World or Make Money?, WALL ST. J. (June 6, 2019), https://www.wsj.com/articles/calpers-dilemmasave-the-world-or-make-money-11560684601 [https://perma.cc/VKF5-SFEA].

185. Significantly, in response to the SEC's request for comment, many investors advocated for greater mandated reporting on sustainability issues precisely because corporate voluntary reporting - aimed at a noninvestor audience - did not highlight the specific matters of interest to investors alone. Ho, supra note 183, at 41-42. 
concern, and seek transparency so that the general public will have an opportunity to influence its exercise. ${ }^{186}$

Thus, information about matters that fall into the sustainability categorylabor conditions, political spending, anti-corruption measures, environmental impact - is primarily sought because it is of societal relevance, and only secondarily (if at all) because it might benefit investors. ${ }^{187}$ The goal, in short, is to make sustainability information relevant to financial performance, even if it is not currently, by empowering noninvestor groups to pressure corporations into improving their behavior. ${ }^{188}$ Far from pursuing investor wealth, much of the sustainability movement is designed to make corporate profits difficult to achieve unless management attends to the needs of noninvestor stakeholders.

There are some types of investors who have an interest in that kind of social activism. Various individuals and groups want to align their investments with their ethical commitments. ${ }^{189}$ Some institutions may invest on behalf of beneficiaries with unified interests in specific issues that the institution seeks to promote, such as labor funds that advocate for worker-friendly policies. ${ }^{190}$

186. Brest et al., supra note 172, at 223-24, 228-29; Choudhury, supra note 170, at 191; Tyler Gellasch, Joint Report: Towards a Sustainable Economy: A Review of Comments to the SEC's Disclosure Effectiveness Concept Release 7-8, AM. FED'N OF LABOR-CONG. OF INDUS. ORG. ET AL. (Sept. 2016) (describing the informational needs of the public and corporate stakeholders, as well as investors, with respect to sustainability data); Green, supra note 150, at 911 (arguing that "shareholders and stakeholders" require more ESG disclosure); Ho \& Park, supra note 169, at 273 (arguing that sustainability reporting "facilitates external oversight of corporations from consumers, NGOs and other Stakeholders"). Additionally, some asset managers appear to have jumped on the sustainability bandwagon as a means of justifying higher fees. Reiser \& Tucker, supra note 173, at 38-39, 49, 52.

187. See, e.g., Todd S. Asgard, Using Non-Environmental Law to Accomplish Environmental Objectives, 30 J. LAND USE \& ENVTL. L. 35 (2014); Deeks, supra note 164, at 405-06.

188. E.g., Green, supra note 150, at 911 (disclosure necessary so that "shareholders and stakeholders" can "hold management accountable"); Hill, supra note 18, at 978-79 (recommending that the securities laws be used to force public companies to disclose repugnant, but legal, business activity in order to facilitate social pressure for change).

189. Schanzenbach \& Sitkoff, supra note 163, at 392-93. So-called "ESG" funds are becoming increasingly popular, and not always for financial reasons; according to one survey, millennials in particular take moral considerations into account when choosing among investments opportunities. EY, SUSTAINABLE INVESTING: THE MiLLENNIAL INVESTOR (2017).

190. David H. Webber, The Rise of the Working Class Shareholder (2018); PJ Himelfarb \& Howard Dicker, Institutional Investors and Advisors Pursue Expanded CEO Pay Ratio Disclosure, GovernANCE \& SeC. WATCH (Dec. 21, 2018), https://governance.weil.com/latestthinking/institutional-investors-and-advisors-pursue-expanded-ceo-pay-ratio-disclosure

[https://perma.cc/ME77-HCDK]; Emily Chasan \& John Gittelsohn, BLOOMBERG (Jan. 14, 2019), California Pension Trustees Call for Disclosures of \#MeToo Costs, https://www.bloomberg.com/news/articles/2019-01-14/california-pension-trustees-call-for-disclosuresof-metoo-costs [https://perma.cc/ERM5-CE35]; NYC COMPTROLLER, Comptroller Stringer, NYC Funds Call on Portfolio Companies to Immediately End Exploitative Labor Practices (Dec. 14, 2018), https://comptroller.nyc.gov/newsroom/comptroller-stringer-nyc-funds-call-on-portfolio-companies-toimmediately-end-exploitative-labor-practices. Teachers' pension funds have also used their investment clout to advocate for children's safety. See Janet Lorin et al., Investors With \$4.8 Trillion Push Gun Industry for Reform, BLOOMBERG (Nov. 14, 2018), https://www.bloomberg.com/news/articles/2018-1114/investors-with-4-8-trillion-push-firearms-industry-for-reform [https://perma.cc/FR8G-Y74S]; JANA PARTNERS \& CALSTRS, Open Letter to Apple, Inc. (Jan. 6, 2018), https://corpgov.law.harvard.edu/2018/01/19/joint-shareholder-letter-to-apple-inc [https://perma.cc/XGF2-WF2J]. 
Thus, it is hardly surprising that the AFL-CIO has explicitly urged that, in setting disclosure standards under the federal securities laws, the SEC adopt a standard for "materiality" that does not turn on financial significance, so long as "reasonable" investors may be concerned about the issue. ${ }^{191}$

That said, these investors are not the norm ${ }^{192}$; many institutional investors are under tight legal restrictions that prevent or minimize their ability to take social concerns into account. ERISA - the statute that governs private retirement plans - has been interpreted to prohibit fiduciary administrators from pursuing anything other than plan wealth maximization, ${ }^{193}$ with social considerations to be used (at most) as a tie-breaker among alternative investments. ${ }^{194}$ The largest investors-mutual fund companies-compete on returns, and witness outflows if they cannot provide them. ${ }^{195}$ Though some fund providers have clearly decided that they can distinguish themselves in a crowded market by adopting some pretense to social responsibility, ${ }^{196}$ they are unlikely to make more than cosmetic overtures toward social concerns distinct from financial performance. ${ }^{197}$ Thus, it is perhaps unsurprising that even funds

191. Letter from Heather Slavkin Corzo, Dir., Office of Inv., AFL-CIO, to Brent J. Fields, Sec'y, SEC (July 21, 2016), https://www.sec.gov/comments/s7-06-16/s70616-305.pdf [https://perma.cc/4JUY-VZH7].

192. See Amir Amel-Zadeh \& George Serafeim, Why and How Investors Use ESG Information: Evidence from a Global Survey, 74 Fin. ANALYSTS J. 87 (2018) (finding that most institutional investors rely on sustainability information for its financial relevance); see also Tommy Stubbington, UK Bond Chief Stheeman Expresses Doubts on Green Gilts, Fin. TimES (Jan. 19, 2020), https://www.ft.com/content/b0b31764-3932-11 ea-a6d3-9a26f8c3cba4 [https://perma.cc/4FRL-BCTE] (observing that investors are not willing to pay a premium for bonds issued to finance environmentally friendly projects).

193. Daniel J.H. Greenwood, Fictional Shareholders: For Whom are Corporate Managers Trustees, Revisited, 69 S. CAL. L. REV. 1021, 1067-68 (1996); David H. Webber, The Use and Abuse of Labor's Capital, 89 N.Y.U. L. REv. 2106, 2125 (2014). In a recent Executive Order, President Trump directed the Department of Labor to generate new guidance to ERISA plans on proxy voting, apparently to ensure that ERISA plans do not seek to improve corporate social performance for reasons unrelated to wealth maximization. Exec. Order No. 13868, 84 Fed. Reg. 15495 (Apr. 10, 2019). Moreover, even retirement plans that are not legally governed by ERISA have adopted ERISA's standards. See Webber, supra note 193193, at 2119-21.

194. U.S. Dep't of Labor, Field Assistance Bull. No. 2018-01 (2018). Some argue that fiduciary obligations even prohibit tie-breaker usage of considerations that do not contribute to plan wealth. See Schanzenbach \& Sitkoff, supra note 163, at 413.

195. Greenwood, supra note 193, at 1067.

196. Jeff Green, The Fearless Girl Is Worth \$7.4 Million in Free Publicity for State Street, BLOOMBERG (Apr. 28, 2017), https://www.bloomberg.com/news/articles/2017-04-28/fearless-girlearns-7-4-million-in-free-media-for-state-street [https://perma.cc/9JBA-AYTT].

197. Larry Fink, the head of BlackRock, penned an open letter to Wall Street CEOs calling for more attention to the social effects of corporate behavior as part of a strategy of long-term, stable growth. See Larry Fink, A Sense of Purpose, https://www.blackrock.com/corporate/investorrelations/2018-larry-fink-ceo-letter [https://perma.cc/CUK3-9XNP]. Commenters immediately pointed out that BlackRock's actual investment behavior has failed to live up to Fink's lofty ideals. See Hamilton Nolan, Larry, The Fink, SPLINTERNEws (Jan. 16, 2018), https://splinternews.com/larry-thefink-1822115671 [https://perma.cc/8L7X-RX6P]; Eric Posner, The Fink Doctrine (Jan. 16, 2018), http://ericposner.com/the-fink-doctrine [https://perma.cc/6P8Y-3TGY]; see also Jan Fichtner \& Eelke M. Heemskerk, The New Permanent Universal Owners: Index Funds, (Im)patient Capital, and the Claim of Long-Termism (Nov. 13, 2018) (unpublished article), https://ssrn.com/abstract=3321597 [https://perma.cc/FFD5-QYGW] (arguing that BlackRock's voting behavior does not align with its professed preference for long-term growth over short-term financial engineering). Activists and 
that purport to devote themselves to ESG strategies often fail to cast their votes in favor of ESG proposals. ${ }^{198}$

The lesson is that even those investors who have the legal freedom, and the incentives, to use their power as investors to press for non-wealth maximizing changes in corporate behavior cannot succeed on their own; to be effective, they must coordinate with noninvestor constituencies - which is the animating force behind the demands for expanded disclosure of nonfinancial information. ${ }^{199}$ But when investors seek corporate information to empower other audiences to assist them in changing corporate behavior, they are not, in a precise sense, seeking investment information; they are seeking information to educate the polity as a whole.

commentators have continued to pressure BlackRock to make a greater commitment to social responsibility. See Leo E. Strine, Address at the Institute for Corporate Governance \& Finance: Fiduciary Blindspot (Nov. 29, 2018); Annie Massa, Larry Fink Confronted by Anti-Gun Protesters at Yahoo Summit, BloomBerG (Sept. 20, 2018), https://www.bloomberg.com/news/articles/2018-0920/larry-fink-confronted-by-anti-gun-protesters-at-yahoo-summit [https://perma.cc/DV8E-238S]. Significantly, Fink's letter did not emphasize corporate social responsibility for its own sake, but pointed out the benefits to stockholders.

Recently, Fink announced that BlackRock would more aggressively factor the risk of climate change into its investment decision making, including demanding more robust disclosures from its portfolio companies. See Larry Fink, A Fundamental Reshaping of Finance, https:/www.blackrock.com/corporate/investor-relations/larry-fink-ceo-letter. This move, as well, was explicitly tied to climate change's relevance to financial performance, and commenters quickly pointed out that many of the divestment initiatives Fink proposed were quite limited and unlikely to affect some of the biggest climate change contributors. See, e.g., Nathaniel Taplin, The Limits of Environmental Activism From BlackRock's Larry Fink, WALL ST. J. (Jan. 21, 2020), https://www.wsj.com/articles/thelimits-of-environmental-activism-from-blackrocks-larry-fink-11579609219 [https://perma.cc/Q38YGPUZ]. In April 2020, BlackRock admitted that, in light of the COVID-19 pandemic, it expected that sustainability reporting would be "de-prioritized." Ross Kerber, BlackRock Says Sustainability Reports Might Slide During Pandemic, ReUTERS (Apr. 22, 2020), https:/www.reuters.com/article/us-healthcoronavirus-blackrock/blackrock-says-sustainability-reports-might-slide-during-pandemic-

idUSKCN2241JP?il=0 [https://perma.cc/9H7V-HSCF].

198. Reiser \& Tucker, supra note 173, at 27; Asjylyn Loder, Funds Don't Always Vote for Policies They Publicly Back, WALL ST. J. (Apr. 2, 2019), https://www.wsj.com/articles/funds-dontalways-vote-for-policies-they-publicly-back-11554206401 [https://perma.cc/9KAJ-J36S]; Patrick Temple-West, Big US Sustainable Funds Fail to Support ESG Shareholder Proposals, FIN. TIMES (Sept. 7, 2019), https://www.ft.com/content/5d342a5d-443d-3327-9502-2361f37f251c [https://perma.cc/KSP2-35UJ].

199. Brest et al., supra note 172, at 223-24, 228-29; James Mackintosh, Even \$1 Trillion Can't Make World Better Place, WALL ST. J. (June 30, 2019), https://www.wsj.com/articles/even-1trillion-cant-make-world-better-place-11561906980 [https://perma.cc/YW4V-NU5R]. The SEC has recognized this coordination function in the context of shareholder proposals. Frequently, shareholders rely on Exchange Act Rule 14a-8 to submit nonbinding requests that corporate directors review or terminate corporate policies the proponent believes to be antisocial, such as a policy of selling semiautomatic rifles in retail stores, see Trinity Wall St. v. Wal-Mart Stores, 792 F.3d 323 (3d Cir. 2015), or manufacturing napalm for use as a weapon, see Medical Comm. for Human Rights v. SEC, 432 F.2d 659 (D.C. Cir. 1970). Though most resolutions do not receive a majority of votes, the SEC has recognized that the publicity associated with them-combined with "management's concern for its reputation and image with its shareholders and with the public at large" - may cause management to change course. Staff Report, supra note 129, at 156-57; see also John J. Flynn, Corporate Democracy: Nice Work If You Can Get It, in CORPORATE POWER IN AMERICA 94, 104 (Ralph Nader \& Mark Green eds., 1973) (arguing that proposal campaigns are "a weapon for focusing public attention on the conduct of corporations in the social, political, and economic spheres"); Alan R. Palmiter, The Shareholder Proposal Process: A Failed Experiment in Merit Regulation, 45 ALA. L. REV. 879, 899 (1994). 
In other words, far from establishing an alignment between the informational needs of investors and the informational needs of the broader society, the sustainability movement itself is attributable to the divergence between the two. The reason that religious orders, ${ }^{200}$ labor unions, ${ }^{201}$ animal rights groups, ${ }^{202}$ human rights groups, ${ }^{203}$ and environmental groups, ${ }^{204}$ among others, position themselves as investors, specifically, when seeking corporate information, is that only investors have a legal lever to pry open the corporate black box. As a result, every new demand for corporate transparency must be filtered through the federal securities laws.

\section{Different Scale}

The concept of "materiality" for investor audiences is tied to the significance of the information relative to the size of the overall business. Issues that might loom large for smaller businesses may have little relevance for larger ones, and disclosure obligations under the securities laws vary accordingly. Such a regime may be appropriate for the informational needs of investors, but is inadequate for the informational needs of the society as a whole.

George Georgiev demonstrates how the materiality threshold in securities law can actually distort markets by handing inherent advantages to larger firms. Companies' securities disclosures provide valuable information that can be used by competitors, employees, and suppliers to gain advantages over the disclosing company, but very large companies may be able to avoid detailed disclosures of subsidiary operations that have only a small effect on their overall business. As a result, these other audiences are at a disadvantage when bargaining with large firms relative to smaller ones, which then hinders the smaller firms' ability to compete. ${ }^{205}$ The natural implication, then, is that

200. Biogen, Inc., SEC No-Action Letter, 2017 WL 697560 (Feb. 23, 2017) (Capuchin Province of St. Joseph)

201. XPO Logistics, Proxy Statement (Sched. 14A) (filed Apr. 17, 2017), https://www.sec.gov/Archives/edgar/data/1166003/000119312517126219/d364074ddef14a.htm

[https://perma.cc/FL4J-H92G] (International Brotherhood of Teamsters on behalf of the Teamsters General Fund).

202. El Pollo Loco Holdings, Proxy Statement (Sched. 14A) (filed Apr. 25, 2017), https://www.sec.gov/Archives/edgar/data/1606366/000162612917000296/epl-def14a_042517.htm [https://perma.cc/2P23-W8FF] (Humane Society).

203. Caterpillar, Inc., SEC No-Action Letter, 2013 WL 416309 (Mar. 25, 2013) (Jewish Voice for Peace). Club).

204. Great Plains Energy, SEC No-Action Letter, 2013 WL 574542 (Feb. 4, 2013) (Sierra

205. Georgiev, supra note 5, at 652-58; see also Willard F. Mueller, Corporate Secrecy vs. Corporate Disclosure, in CORPORATE POWER IN AMERICA 111, 112 (Ralph Nader \& Mark Green eds., 1973). 
businesses should be required to disclose information regardless of its materiality to investors, in order to confer broader benefits on society. ${ }^{206}$

The same is true of sustainability information. As Virginia Harper Ho observes, "companies may determine that even multibillion dollar risk exposure is immaterial for reporting purposes, even if a risk event could cause devastating losses or impose high social welfare costs on the public." 207

The problem has only been exacerbated in recent years. Whether due to lax antitrust enforcement ${ }^{208}$ or for other reasons, publicly traded companies have grown dramatically in size, often gobbling up their smaller competitors. ${ }^{209}$ The result is that details of their business operations are increasingly obscured from public view on the ground that individual contributors to their financial performance are not material to the firm as a whole. ${ }^{210}$ Amazon, for example, does not disclose revenue attributable to Prime subscribers, ${ }^{211}$ and Google's parent company only recently began disclosing revenues attributable to its YouTube subsidiary, while continuing to omit information about the division's profits and losses. ${ }^{212}$ Indeed, it is likely that because YouTube is folded into the

206. Georgiev, supra note 5, at 658-62. Georgiev argues that the National Securities Markets Improvement Act of 1996 authorized the SEC to require disclosures that will generally facilitate "competition," beyond what is needed for investor protection or market efficiency, apparently envisioning an audience of noninvestors. Id. at 661. It is hard to know if this is a correct interpretation of the statute, as the NMSIA's legislative history is notoriously sparse, James D. Cox \& Benjamin J.C. Baucom, The Emperor Has No Clothes: Confronting the D.C. Circuit's Usurpation of SEC Rulemaking Authority, 90 TEX. L. REV. 1811, 1818 (2012), but an alternative reading would be that it was intended to foster competition among certain SEC-regulated entities, see H.R. REP. NO. 104-622, at 16, 30 (1995); J.W. Verret, Economic Analysis in SEC Enforcement: The Next Frontier at the SEC, 82 U. CIN. L. Rev. 491, 496-97 (2013). Assuming Georgiev's reading is accurate, Congress - as well as the SEChave broadened the mechanisms by which companies can raise capital privately and thus avoid securities disclosure entirely. See supra Section II.A. As a result, the SEC is necessarily hobbled in any attempt to foster "competition" via securities disclosure; too many companies are simply outside of its purview.

207. Ho, supra note 161, at 441. A similar argument may be made about political spending; shareholder audiences may be far less concerned about small expenditures than voter audiences. See Haan, supra note 91, at 2686.

208. Lina M. Khan, Note, Amazon's Antitrust Paradox, 127 YALE L.J. 710, 717-35 (2017).

209. James D. Cox, Thinking Holistically Before Dropping Quarterly Reporting, CLS BLUESKY BLOG (Aug. 27, 2018), http://clsbluesky.law.columbia.edu/2018/08/27/thinking-holisticallybefore-dropping-quarterly-reporting [https://perma.cc/YT4P-BYR5]; Sarah Ponczek \& Reade Pickert, How Did the U.S. Stock Market Get So Old?, BloOMBERG (March 5, 2019), https://www.bloomberg.com/news/articles/2019-03-05/how-did-the-u-s-stock-market-get-so-old [https://perma.cc/87QT-PYWQ].

210. Georgiev, supra note 5, at 630-32, 636-37 (discussing how major acquisitions, and lawsuits alleging serious lawbreaking or threats to public safety, may not be disclosed). Some of these matters may (though not always, see id. at 630-31) be publicized outside of the securities laws, but having the information in a clearly designated space as part of a generalized portrait of a single company carries its own power.

211. The SEC has attempted to force these companies to disclose more information about their internal operations, but so far, has acquiesced to the argument that the details would not contribute to investor comprehension. Michael Rapoport, What Amazon Isn't Telling Investors About Its Revenue, WALL ST. J. (Dec. 22, 2018), https://www.wsj.com/articles/what-amazon-isnt-telling-investors-aboutits-revenue-11545480000 [https://perma.cc/NC95-LQMD].

212. Patience Haggin, What Investors Learned From the First Peek Inside YouTube's Financials, WALL ST. J. (Feb. 4, 2020), https://www.wsj.com/articles/what-investors-learned-from-thefirst-peek-inside-youtubes-financials-11580836322 [https://perma.cc/5MRN-VLQE]. 
larger Alphabet/Google corporation, YouTube's CEO has escaped the political scrutiny that other, more prominent tech CEOs have endured in recent years, ${ }^{213}$ despite the incendiary content that the platform hosts (and has even encouraged). ${ }^{214}$

\section{Historical Calls for Stakeholder-Oriented Disclosure}

The American system of exclusively marrying corporate disclosure to public investment is unusual. In many other parts of the world, all but the smallest corporations are required to disclose basic information for public consumption. ${ }^{215}$ Yet America's regime is no accident: As this Part demonstrates, it is the result of a series of historical compromises whereby mandatory disclosure for investor audiences was used to quell calls for more generalized disclosure. As we shall see, that compromise was doomed from the outset, because an investor-oriented disclosure system tilts corporate behavior more toward wealth maximization and away from social responsibility, which only heightens the need for corporate accountability to the public.

\section{A. Progressive Era Corporate Regulation}

The earliest business corporations were controlled by limitations installed directly into their charters. Legislators granted permission to incorporate on a case by case basis and defined the precise boundaries of the undertaking; actions outside that sphere were void or voidable via doctrines of ultra vires and quo warranto. ${ }^{216}$ Charters could only be amended by the unanimous consent of shareholders - an impossibly high bar that tightly constrained corporate activity. ${ }^{217}$ A variety of mechanisms kept corporations small in size, including prohibitions on holding companies and restrictions on corporate

\footnotetext{
213. Daisuke Wakabayashi, The Most Measured Person in Tech Is Running the Most Chaotic Place on the Internet, N.Y. TIMES (Apr. 17, 2019), https://www.nytimes.com/2019/04/17/business/youtube-ceo-susan-wojcicki.html [https://perma.cc/DQ76-Q5AY].

214. Mark Bergen, YouTube Executives Ignored Warnings, Letting Toxic Videos Run Rampant, BloOMBERG (Apr. 2, 2019), https://www.bloomberg.com/news/features/2019-04-02/youtubeexecutives-ignored-warnings-letting-toxic-videos-run-rampant [https://perma.cc/F9CU-8G6H]. In recent months, YouTube has clearly experienced some pressure to reform its practices, Kevin Roose \& Kate Conger, YouTube to Remove Thousands of Videos Pushing Extreme Views, N.Y TIMES (June 5, 2019), https://www.nytimes.com/2019/06/05/business/youtube-remove-extremist-videos.html

[https://perma.cc/Q74V-XH6Z], but its internal governance has still received nothing like the scrutiny of firms like Facebook that are forced to make their operations public.

215. See supra Introduction; see also infra Section V.A.1.

216. HURST, supra note 155, at 45; Elizabeth Pollman, Constitutionalizing Corporate Law, 69 VAND. L. REV. 639, 648 (2016).

217. Pollman, supra note 216, at 648 .
} 
finances. ${ }^{218}$ In this manner, corporate regulation was entirely melded with the corporation's organizing documents and authorization to act.

Though these restrictions functioned partly to protect investors, they "responded also to the fear that incorporation would help some enterprises upset the market's capacity to function as a guarantor of a healthy economic balance of power." 219 Barriers to growth functioned as a species of antitrust regulation - the overwhelming regulatory concern of the time ${ }^{220}$ - protecting not only consumers from inflated prices, but also labor from exploitative wages, ${ }^{221}$ and even independent entrepreneurs (potential competitors) from being forced into what was viewed as a servile "employee" status. ${ }^{222}$ More generally, limitations on economic power were viewed as necessary to protect the political system from co-option by monied interests. ${ }^{223}$

Such blunderbuss restrictions, however, could not survive the country's economic development, especially as states began to compete with each other to draw incorporations - and thus economic activity - to their territories. ${ }^{224}$ In 1889 , New Jersey became the first state to permit corporations to own stock in other companies (an action that earned it the moniker of "traitor state"), ${ }^{225}$ and the "rapid capitulation" of other states followed. ${ }^{226}$

With New Jersey having broken the seal of restrictions on corporate holding companies, giant corporations grew rapidly, transforming the landscape of American economic organization. These corporations were financed by the public sale of securities. Between 1896 and 1907, the number of shares traded on the NYSE more than quadrupled, growing from 57 million to 260 million. ${ }^{227}$ After World War I, in what was described as "the passing of ownership from Wall Street to Main Street," securities ownership spread rapidly throughout the population. ${ }^{228}$

218. Morton J. Horwitz, The Transformation of American Law 1870-1960, at 83, 87 (1992). For example, state law might limit corporate capitalization or the value of the assets corporations could hold. See HURST, supra note 155, at 45.

219. HURST, supra note 155 , at 47.

220. HORWITZ, supra note 218 , at 80.

221. Jeremiah W. Jenks, Address to Chicago Conference on Trusts (Sept. 1899), in CHICAGO CONFERENCE ON TRUSTS: SPeEChes, Debates, Resolutions, Lists OF the Delegates, COMmitTeEs, ETC. 27, 31-32 (Civic Fed'n of Chi. ed., 1900) [hereinafter ChicAGo CONFERENCE] (reserving that evidence of this effect was not dispositive); John Hayes, CHICAGO CONFERENCE, supra, at 331 .

32.

222. Michael J. SANDEl, DemOCRACY's DisCONTENT 185 (1996); Jenks, supra note 221, at

223. Khan, supra note 208, at 740; see also Woodrow Wilson, Address Before the American Bar Association: Before the War: How Things Looked Then (1910) (warning that if corporations are not limited, they will "dominate the bodies politic themselves").

224. HoRwITZ, supra note 218, at 84.

225. Id. at 83 .

226. Id. at 84 .

227. Id. at 75 .

228. William Zebina Ripley, Main Street and Wall Street 116 (1927); see also H.R. REP. NO. 57-3375, at 17 (1903) (“All classes invest.”). 
The Progressives observed that the corporate form permitted great aggregations of capital that went far beyond what a single proprietor could achieve on his own, magnifying the ability of a small number of people to do a substantial amount of harm. ${ }^{229}$ Once corporations reached this size, they could no longer be considered "private" institutions; they became subject to, as Hillary Sale might put it, publicness, with associated public obligations. ${ }^{230}$ William Z. Ripley, a legal scholar of the era, warned, "Little personal enterprises pass almost imperceptibly over into great formless aggregations in which what is everybody's business threatens to become nobody's business." 231

The result of all of this was a new attempt to regulate corporate activity through limits on the corporate form itself. But because this effort had failed at the state level - in part due to the race to the bottom ${ }^{232}$ - renewed attempts focused on Congress. Thus, the first third of the twentieth century saw countless proposals for federal chartering, ${ }^{233}$ with a focus on limiting corporate structure as a means of limiting corporate activity. Multiple proposals, usually in combination with these chartering attempts, sought to force disclosure of corporate activity (or "publicity," as it was dubbed at the time) as a critical regulatory mechanism. ${ }^{234}$

For example, in 1901 and again in 1903, Representative Littlefield introduced a bill that would require corporations operating in interstate commerce to file returns with the Interstate Commerce Commission containing basic information about the corporation's finances and capital structure. ${ }^{235}$ Summaries of the returns would then be published. ${ }^{236}$ These obligations were

229. HURST, supra note 155, at 47; Dalia Tsuk Mitchell, Shareholders as Proxies, 63 WASH. \& LEE L. REV. 1503, 1523-24 (2006).

230. See Berle \& MeAns, supra note 146, at 7 (describing these new, giant enterprises as "quasi-public," with associated obligations "towards the owners, the workers, the consumers, and the State"); see also REPORT OF THE COMMISSIONER OF CORPORATIONS FOR 1908, H.R. DOC. NO. 60-1048, at 309 (1909) (stating that managers of large corporations are "affected with a public trust"); Horwitz, supra note 218 , at 101,104 ; .

231. RIPLEY, supra note 228, at 131; see also id. (quoting the president of General Motors: "[T]he public interest becomes involved when the public can no longer locate some tangible personality within the ownership which it may hold responsible for the corporation's conduct.").

232. H.R. REP. NO. 57-3375, at 23 (1903) (characterizing the "financial incentive" for states to "furnish an asylum and breeding place for vicious, unrestrained, corporate vagrants" as "too strong for human nature to withstand."); see also RIPLEY, supra note 228, at 28-37, 165; Loomis Jr. \& Rubman, supra note 51 , at 161 (discussing the contemporary derision of "charter mongering" states).

233. Some proposed federal "licensing" rather than chartering, though there were few practical differences and many commentators did not distinguish between them. Melvin I. Urofsky, Proposed Federal Incorporation in the Progressive Era, 26 AM. J. LEGAL HIST. 160, 166 (1982).

234. RIPLEY, supra note 228 , at 221 . At this time, of course, there were no general corporate disclosure requirements. States would eventually begin to require that some disclosure accompany the sale of securities, and the New York Stock Exchange required that listed companies disclose information about corporate finances, but these regimes were weakly enforced and easily evaded. See Seligman, supra note 49, at 46-47. And though at one time, the Bureau of the Census disclosed information about corporate activity, that practice ended with the passage of the Sherman Act in 1890. See Mueller, supra note 205, at 124.

235. Marjorie E. Kornhauser, Corporate Regulation and the Origins of the Corporate Income Tax, 66 IND. L. J. 53, $72-73$ (1990).

236. Id. at 73 . 
not tied to the public sale of securities, and the committee report on the bill made clear that publicity was intended for general consumption, including consumers, employees, and regulators. ${ }^{237}$

In 1903, Congress created the Bureau of Corporations, authorizing it to investigate individual companies and publish their particulars. ${ }^{238}$ (Earlier proposals would have made publication mandatory.) ${ }^{239}$ James Garfield, the first Commissioner of Corporations, called for legislation that would allow for general disclosure of corporate information for public consumption, ${ }^{240}$ and his successor, Herbert Smith, did the same, urging Congress to address the "problem of corporate regulation" via a "broad system of corporate publicity." ${ }^{241}$ Commissioner Smith went on to clarify that such publicity should "reach[] the average citizen under everyday conditions."242

In 1909, Congress passed an income tax on corporations, not so much for revenue collection as to force corporate disclosure of finances, which would then (as originally conceived) be made publicly available. ${ }^{243}$ The law did not distinguish between corporations with public investors and those that were closely held, and even those with too little income to be subject to the tax were still required to file returns, which would then be publicly disclosed. ${ }^{244}$ Speaking in support of the tax, President Taft said, "If now, by a perfectly legitimate and effective system of taxation, we are incidentally able to possess the Government and the stockholders and the public of the knowledge of the real business transactions and the gains and profits of every corporation in the country, we have made a long step toward that supervisory control of corporations which may prevent a further abuse of power." 245

Even after the passage of the corporate tax, a flurry of other bills called for public disclosure of finances, capitalization, and business operations of corporations engaged in interstate commerce, without regard to whether their

237. H.R. 17, 57th Cong. (1903); H.R. REP. No. 57-3375 (1903). The bill eventually passed the House but was never voted in the Senate. Kornhauser, supra note 235, at 73 n. 73 .

238. Law of Feb. 14, 1903, 32 Stat. 825. The fact that the president could choose to publish, or not, demonstrates that the publicity was not intended for investors specifically. See Camden Hutchison, Progressive Era Conceptions of the Corporation and the Failure of the Federal Chartering Movement, 2017 Colum. Bus. L. Rev. 1017, 1059 (2018).

239. See Hutchison, supra note 238, at 1059. Later commentators expressed dismay at the change. See Control of Corporations, Persons, and Firms Engaged in Interstate Commerce: Hearing on S. 2941 Before the S. Comm. on Interstate Commerce, 62d Cong. 157 (1913) (statement of Henry B. Martin).

240. RIPLEY, supra note 228, at 221.

241. RePORT OF THE COMMISSIONER OF CORPORATIONS FOR 1908, H.R. DOC. NO. 60-1048, at 306 (1909).

242. Id. at 306-07; RIPLEY, supra note 228 , at 221 . The proposed system would be voluntary, rather than compulsory, but participating corporations would be entitled to special privileges.

243. Kornhauser, supra note 235, at 113-18.

244. Id. at 120 .

245. Id. at 100 . 
securities were offered to the public. ${ }^{246}$ Though many advocates for publicity were not entirely clear on whether they intended for disclosure solely to government regulators or to public in general, ${ }^{247}$ when they did specify they intended disclosure to the public, they explained that their goals were to force corporations to attend more to the general social effects of their activities. ${ }^{248}$

At the time, it was believed that trust combinations were formed as a result of overcapitalization, namely, the sale of securities and the promise of dividends without sufficient assets to back them. Commenters argued that corporate managers would then resort to unscrupulous business methods to pay the dividend, including overcharging consumers and exploiting labor. ${ }^{249}$ In today's parlance, we might call this a rebellion against shareholder wealth maximization: disclosure was viewed as a mechanism for empowering noninvestor constituencies to reclaim economic rents. ${ }^{250}$ Advocates for

246. E.g., H.R. 17932, 62d Cong. (1912) (reintroduced in 1913 as H.R. 9763); S. 4647, 63d Cong. (1914); S. ReP. No. 63-1326 (1913) (describing S. 5485, 62d Cong. (1912) and associated amendments). Because the disclosure required by the 1909 tax law was never fully put into effect, see Section III.A infra, there were also new efforts to make tax returns public. Blank, supra note 110, at 4344.

247. Kornhauser, supra note 235, at 72; see, e.g., 1 IndUS. COMM'N, PRELIMINARY REPORT ON TRUSTS AND INDUSTRIAL COMBINATIONS 1109-110 (1900) [hereinafter INDUS. COMM’N REP.] (testimony of Charles N. King) (conflating annual reporting for the public with reporting for stockholders).

248. Hutchison, supra note 238, at 1049 (“Among anti-corporate reformers, "publicity' was widely viewed as a safeguard against monopolistic pricing . . . . To these commentators, shareholder protection was generally not a major concern, though it was sometimes cited as an additional benefit ... ."). As part of his 1910 campaign for a third presidential term, former President Theodore Roosevelt forcefully advocated for "complete and effective publicity of corporate affairs, so that the people may know beyond peradventure whether the corporations obey the law and whether their management entitles them to the confidence of the public." See Megan Sack, From the Archives: President Teddy Roosevelt's New Nationalism Speech, THE White House BLOG (Dec. 6, 2011), https://obamawhitehouse.archives.gov/blog/2011/12/06/archives-president-teddy-roosevelts-newnationalism-speech [https://perma.cc/44E3-6KSY].

249. Kornhauser, supra note 235, at 77-79; H.R. REP. No. 57-3375, at 6 (1903) (quoting testimony of James Dill, the attorney who designed New Jersey's corporation law, concluding that overcapitalization "results either in a robbing of the capital or in a resorting to artificial means to earn that dividend, which artificial means commonly consist, in addition to putting up the price of material, in putting down the price of labor."); 40 CONG. REC. 1849 (Jan. 31, 1906) (statement of Congressman Martin) (an overcapitalized company has "only two ways known" to pay dividends to investors; "One is to advance the prices upon the commodity which the people must pay, and the other is to reduce the cost of production, and often this is accomplished by a reduction of the wages of workingmen. Overcapitalization therefore becomes an enemy not only of the honest investor attracted to the stock, but it becomes also an enemy of the honest laborer engaged in the manufacture of that product, as well as an enemy to the consuming public called upon to pay the increased price.").

250. The Committee Report for the Littlefield Bill was explicit on this logic:

it is through the medium of consumers, the purchasers of its products, that the overcapitalized combination finds its most extensive and oppressive contact with the public .... The purpose to create for the stock a fictitious value and thus arbitrarily increase the wealth of the persons interested is undoubtedly the main purpose in overcapitalization. In order to accomplish this, in nearly every instance the price to the consumer must either be increased or maintained above its natural normal level .... There are instances where corporations have increased their capitalization 100 per cent in order that what was really, say, a 12 per cent dividend would appear to be only a 6 percent dividends, and thus avoided the danger of making their employees uneasy and restive because they were not receiving in wages a fair proportion of 
disclosure of corporate finances and business methods argued-much as has been argued today - that reports of excess profits would prompt consumer and employee rebellion, and invite competitors to enter the market. ${ }^{251}$ As one businessman testified before Congress in 1911:

Suppose we started out and the published reports of our second year showed that we had made 40 or 45 per cent profit — absolutely exorbitant profit-I believe public opinion would get after us, and we would be fools not to reduce our profit to a reasonable amount. I believe it would force us out . . . Because it would encourage competition to enter that field immediately. ${ }^{252}$

Indeed, Louis Brandeis was famous for arguing that disclosure of underwriting commissions would lead to the equivalent of a capital strike, and thus help break the "money trust." 253 Commentators also argued that discriminatory pricing - a practice that would eventually be prohibited outright ${ }^{254}$ — could be combatted by forcing corporations to disclose their prices publicly. ${ }^{255}$ In 1906, the Bureau of Corporations did just that with respect to preferential shipping rates charged to Standard Oil, prompting the railroads to reform their practices. ${ }^{256}$

Advocates additionally stressed that disclosure would inform regulators so they could craft tailored solutions to particular problems. ${ }^{257}$ At the 1899

the earnings of the business .... Publicity, by creating an intelligent public sentiment, will go far toward ameliorating oppressive conditions.

H.R. REP. NO. 57-3375, at 22 (1903) (emphasis added); see also RIPLEY, supra note 228, at 168 ("Wage earners, whether interested as incipient capitalists or not, certainly feel as they become class-conscious that they have a right to know what is the relation of the return for the work of their hands to the rewards which accrue to the employer ...."). This attitude was, of course, not universal; many commenters argued that capitalization was simply what people would pay based on expected profit, and as long as facts were disclosed there was no problem. See, e.g., W. Bourke Cochran, ChiCAGo ConfEREnCE, supra note 221, at 470 .

251. See, e.g., Control of Corporations, Persons, and Firms Engaged in Interstate Commerce: Hearing on S. 2941 Before the S. Comm. on Interstate Commerce, 62d Cong. 995-1024 (1913) (statement of Lawrence Laughlin); H.R. REP. No. 57-3375, at 4 (1903) (quoting the Industrial Commission report from 1900, recommending that the largest corporations publish detailed financial statements "to encourage competition when profits become excessive, thus protecting consumers against too high prices and to guard the interests of employees by a knowledge of the financial condition of the business which they are employed."); Jenks, supra note 221, at 30-34 (noting concerns about overcapitalization, and suggestions that disclosure would protect investors and consumers, and invite competition); RIPLEY, supra note 228, at 167 ("revelation of profits by concerns which threaten to oppress the public would operate almost automatically ... to invite corrective competition").

252. See Control of Corporations, Persons, and Firms Engaged in Interstate Commerce: Hearing on S. 2941 Before the S. Comm. on Interstate Commerce, 62d Cong. 1040-41 (1913) (statement of C.U. Carpenter).

253. BRANDEIS, supra note 1, at 102-04.

254. 15 U.S.C. $\$ 13(2018)$.

255. An Act to Regulate Commerce, Etc.: Hearings on House Bill 19745, 60th Cong. 77 (testimony of Theodore Marburg); REPORT OF THE COMMISSIONER OF CORPORATIONS FOR 1908, H.R. Doc. No. 60-1048, at 307 (1909); W. Bourke Cochran, CHICAGo CONFERENCE, supra note 221, at 468.

256. H.R. Doc. No. 60-1048, at 307.

257. Control of Corporations, Persons, and Firms Engaged in Interstate Commerce: Hearing on S. 2941 Before the S. Comm. on Interstate Commerce, 62d Cong. 1040-19 (1913) (statement of Sen. 
Chicago Conference on Trusts, ${ }^{258}$ one speaker explained, "Shall [trusts] be brought under the light of publicity and examination so that the good and bad in their tendencies can be better determined . . . ? It is the right of society to know if this new-born creature of conditions is humanity's offspring or is a coiled serpent." 259 Corporations Commissioner Garfield argued that disclosure would permit government regulators to pin responsibility for corporate misconduct on specific individuals, and thereby deter such wrongs in the first place, while also allowing the "people of our country [to] form an intelligent opinion of industrial conditions, and not be driven to extreme and unwise action by the clamor of those who assail all great corporate interests because some have done ill." 260 The notion that disclosure would educate the public and permit a national conversation about the wisdom of great corporations was a common theme in commentary. ${ }^{261}$

More generally, there was an inchoate sense that disclosure would simply deter all forms of business misconduct. ${ }^{262}$ As Marjorie Kornhauser points out, this was the era of muckraking; it was believed that exposure would eventually lead to change. ${ }^{263}$ Testifying before the Senate in 1911, Elbert Gary, the chair of US Steel, opined that "We were early taught that the one who loves darkness

Newlands) (describing a bill for corporate publicity he had introduced: "Its primary result will be to furnish both to Congress and to the public the accurate and broad information on corporate conditions that is necessary to determine the line of further advance."); H.R. REP. NO. 57-3375, at 22-23 (1903) ("It is not claimed that publicity is a cure-all. . . Full publicity should add materially to our information on this abstruse subject, and enable us ... to act more intelligently and efficiently in enacting legislation . . .."); Kornhauser, supra note 235, at 80 .

258. The conference was convened by the Civic Federation of Chicago to discuss the trust issue, and was attended by a "wide range of figures from government, academics, journalism, labor, the legal profession, and elsewhere." Hutchison, supra note 238, at 1034.

259. William Fortune, CHICAGO CONFERENCE, supra note 221, at 56-57; see also H.R. DOC. No. 60-1048, at 309 ("Such supervision and the making and reviewing of regular reports will necessitate constant contact and conference between [the government and industry]. This is perhaps its greatest advantage. So complex a subject-matter as our immense industrial machinery can not be intelligently adjusted without constant conference by all parties concerned."); William Dudley Foulke, CHICAGO CONFERENCE, supra note 221, at 582 ("Periodical statements and examinations should be made not only of stock, salaries, property, dividends, wages, prices of materials bought and goods sold, but of all other matters which tend to throw light upon the condition of the corporation and its management of the particular industry involved. This publicity will restrain many abuses, and it will throw light upon the question as to what further legislation is needed.").

260. RIPLEY, supra note 228, at 221-22.

261. Corporations Commissioner Smith expressed the same view in a subsequent report: "Such a system [of disclosure] will give the information necessary to make public opinion intelligent ... . Public opinion, now disturbed by a knowledge of the unfair and illegal methods of a comparatively few corporate managers, will thus have the facts as to all large concerns and be able to discriminate between the few evil doers and the great mass of fair and law-abiding companies." H.R. DOC. No. 60-1048, at 308-09. Similarly, a speaker at the Chicago Conference opined that with publicity, "The people meanwhile will be rapidly educated.... Economic discussion is at last so far popularized that the people will take a passionate interest in the coming debate... No industrial event ever gave a more magnificent occasion for education upon what is deepest in the so-called social question." John Graham Brooks, CHICAGO CONFERENCE, supra note 221, at 61.

262. Hutchison, supra note 238, at 1038 (observing that progressive reformers "were rarely clearer in justifying publicity's importance, though they presented it as a panacea for a host of economic issues").

263. Kornhauser, supra note 235, at 75. 
is the one whose deeds are evil, and that is particularly true of business life. There is nothing like publicity - allowing the public to look into a company to see what it is doing, to know what its figures are." ${ }^{264}$ Or, as one academic colorfully put it, "I think any man who has been abroad as much as I have and seen the difference between the way a young man behaves at home and the way he behaves in Turkey will agree that a little publicity - the watchful eye of a friend there - is a very powerful influence in making him decent." 265

In truth, at least some of the enthusiasm for disclosure as a mechanism of regulation was surely rooted in the expectation that it would stave off more onerous government intervention. ${ }^{266}$ One JP Morgan partner gave the game away when he told Congress that "I believe so thoroughly that publicity of the right sort would be a very strong deterrent on the management of any company from doing anything that was not right, and would be so convincing to the public that what was done was being done right, that we would find ourselves relieved from the necessity of resorting to a long schedule of fixed rules, which were to the effect, 'Thou shalt not,' 'thou shalt not,' and 'thou shalt not."'267 Still, commentators from all ends of the spectrum argued that "what was then commonly referred to as 'pitiless publicity' was desirable as to corporate matters," 268 for the benefit of the consuming and laboring public.

At the same time - and in somewhat contradictory fashion - it was also agreed that overcapitalization was bad for investors, because (in an echo of those who critique the allegedly short-termist outlook of managers today) ${ }^{269}$ even though they would reap outsized dividends for a time, the profits thereby generated were unsustainable, which would eventually result in a market crash. ${ }^{270}$ This, too, would be cured by disclosure, as investors would be unwilling to buy securities in a venture that did not have sufficient assets to justify the prices. ${ }^{271}$

264. Control of Corporations, Persons, and Firms Engaged in Interstate Commerce: Hearing on S. 2941 Before the S. Comm. on Interstate Commerce, 62d Cong. 696 (1913) (statement of Elbert Gary); see also H.R. Doc. No. 60-1048, at 307 ("Again and again the mere exposure of improper business methods has led to their abandonment without any further action.").

265. Control of Corporations, Persons, and Firms Engaged in Interstate Commerce: Hearing on S. 2941 Before the S. Comm. on Interstate Commerce, 62d Cong. 747-48 (1913) (statement of John Gray).

266. Kornhauser, supra note 235 , at 81.

267. Control of Corporations, Persons, and Firms Engaged in Interstate Commerce: Hearing on S. 2941 Before the S. Comm. on Interstate Commerce, 62d Cong. 1125-26 (1913) (statement of George W. Perkins); see also id. at 534 (statement of Seth Low). Corporatists may also have supported publicity to avoid a "market for lemons" problem and differentiate themselves from more speculative or fraudulent ventures. Hutchison, supra note 238, at 1050.

268. Letter from Chairman of the Federal Trade Commission, S. Doc. No. 70-92 pt. 69-A., at exh. 6083 (1934).

269. James Park, Do the Securities Laws Promote Short-Termism?, 10 U.C. IRVINE L. REv. $991(2020)$

270. H.R. REP. No. 57-3375, pt.1, at 3-4, 19; Kornhauser, supra note 235, at 77; Edward Rosewater, CHICAGO CONFERENCE, supra note 221, at 459-60.

271. Hutchison, supra note 238, at 1049; e.g., INDUS. COMM'N REP., supra note 247, at 15 (statement of F.B. Thurber) ("You are going to see, within a year or two, a crash in these industrials, in 
Eventually, it was this sort of divide and conquer that did the Progressive movement for publicity in. Canny commentators distinguished between disclosure intended for regulators (which could then be concealed from the public), and disclosure intended for investors, which would only be necessary for companies that sought public investment. ${ }^{272}$ Disclosure for other audiences generally fell by the wayside. John R. Dos Passos, an attorney who was instrumental in building the Sugar Trust, testified in 1899 that he understood that investors and the government may have need of some information, but:

[I]f you were to make a law by which the whole public could pass through the office of a corporation and look at its affairs as you would pass through a street and look through the windows into an office to discover what was going on there-I say that such a license to the general public would be infringing the rights of the corporation - it would be infringing individual rights; you would be guilty of transcending the power of government. ${ }^{273}$

Through arguments along these lines, opponents gutted the disclosure aspects of the 1909 Corporate Tax, first by Treasury regulation, and then by a statutory amendment that gave the president authority to determine when to make returns public. The subsequent rulemaking provided that only the returns of companies that sought public investment would be published; for closely held corporations, stockholders alone would have a right of inspection if they could show a proper purpose, not unlike the inspection rights that usually existed under state law. ${ }^{274}$

These rules thus became the antecedents of the Securities Acts, passed in 1933 and 1934, which explicitly required disclosure only geared to investors,

which the resources of thousands and thousands of people who have put their money into these securities will be wiped out; and the only remedy that I can see is such control as will require publicity.").

272. See, e.g., Azel F. Hatch, ChicAGo Conference, supra note 221, at 71 (recommending publicity for investor protection, when the public is invited to purchase securities); F.B. Thurber, CHICAGO CONFERENCE, supra note 221, at 131 (only investors require the protection of publicity); Aaron Jones, CHICAGO CONFERENCE, supra note 221, at 220 (recommending disclosure to government for purposes of regulation); John M. Stahl, CHICAGO CONFERENCE, supra note 221, at 224 (same); Kornhauser, supra note 235, at 81 (discussing how the National Association of Manufacturers argued disclosure was necessary only for companies that offered securities publicly); Abram F. Myers, Federal Regulation of Corporations Under the Commerce Clause, ANNALS AM. ACAD. POL. SOC. SCI. 143, 147 (1927) (recommending disclosure to the government and to investors and noting that the informational needs of the general public may be satisfied by anonymized government publications "for the purpose of guiding business development and promoting business stability"). As a result, in addition to bills calling for generalized publicity, numerous other bills were put forth during this period specifying that disclosure was intended only for government regulators or investors. See, e.g., S. 6238, 58th Cong. (1905) (disclosure to government); H.R. 10704, 59th Cong. (1906) (same); H.R. 66, 58th Cong. (1903) (reports to stockholders); S. 1612, 67th Cong. (1921) (disclosure for corporations that sell securities publicly); H.R. 188, 66th Cong. (1919) (same).

273. INDUS. COMM'N REP., supra note 247, at 1164 (statement of John R. Dos Passos).

274. Kornhauser, supra note 235, at 125-31. 
and only when securities were offered to the general public. ${ }^{275}$ At first, the securities disclosure regime nodded toward public informational needs by housing regulatory authority in the Federal Trade Commission (FTC); even that concession, however, was eliminated with the creation of the Securities and Exchange Commission in 1934. ${ }^{276}$ Meanwhile, Congress provided that the FTC and other agencies collect corporate data for government use. ${ }^{277}$ Though this data was sometimes compiled into public reports, the reports spotlighted industry trends without providing ongoing transparency regarding individual companies. ${ }^{278}$

That said, the Securities Acts and the disclosure they required resulted in many of the positive externalities that earlier proponents of publicity hoped to achieve directly. ${ }^{279}$ Eventually, much of the substantive regulation sought by federal chartering was shunted into external regulatory systems, ${ }^{280}$ with each area of concern addressed separately via different federal agencies, and little attention paid to the notion of disclosure to the public as a generalized regulatory tool. By 1938, World War II had derailed the project of federal chartering altogether, putting the issue on the backburner for the next several decades.

The great irony, then, is that commenters of the Progressive Era sought to make corporations more responsive to the needs of the general public, but by acquiescing to a disclosure system predicated only on the needs of investors, they granted investors - over employees, consumers, and the surrounding community - a privileged position in the corporate hierarchy. Though other agencies did (and in the future, would) attend to these other interests, ${ }^{281}$ only

275. Id. at 131. At the time, Ferdinand Pecora defended the limited nature of the Securities Act of 1933 on the ground that "If there is a rainstorm, and an umbrella is not handy, a newspaper might sometimes give shelter temporarily." Loomis Jr. \& Rubman, supra note 51, at 165-66.

276. SELIGMAN, supra note 49, at 70-72, 97-99.

277. Stanley E. Boyle, Economic Reports and the Federal Trade Commission: 50 Years Experience, 24 FED. B.J. 489 (1964).

278. On several occasions the FTC's investigative powers became a political football, with Congress withholding funds and industry lobbying to defeat various reporting requirements. $I d$. at 493 94, 500-01; David J. Ravenscraft \& Curtis L. Wagner III, The Role of the FTC's Line of Business Data in Testing and Expanding the Theory of the Firm, J.L. \& ECON. 703, 706-07 (1991); see also RALPH NADER ET AL., TAMING THE GIANT CORPORATION 135 (1976).

279. For example, the Exchange Act forced disclosure of cost of sales, enabling both competitors and customers to examine - and exploit-large profit margins. Merritt B. Fox, Retaining Mandatory Securities Disclosure: Why Issuer Choice Is Not Investor Empowerment, 85 VA. L. ReV. 1335, $1353-54$ n.33 (1999).

280. Hutchison, supra note 238, at 1096. For example, though federal chartering proposals often prohibited interlocking directorates among competing companies, these were eventually prohibited in the Clayton Act. 15 U.S.C. $\S 19$ (2018). Issues pertaining to employee wages and unionizing were addressed with minimum wage and labor laws. See Adam Winkler, Corporate Law or the Law of Business?, 67 L. \& CONTEMP. PROBS. 109 (2004).

281. Those other agencies include the Consumer Product Safety Commission and the Food and Drug Administration for consumers, the Equal Employment Opportunity Commission and the Occupational Safety and Health Administration for workers, the Environmental Protection Agency for communities, and so forth. 
Not Everything Is About Investors

investors received generalized disclosure, with all of its potential as a mechanism for pressuring corporations outside of the regulatory system.

\section{B. 1970s Revitalization of the Corporate Governance Movement}

Corporate theory and associated proposals for corporate governance reform subsided post-World War II. ${ }^{282}$ Meanwhile, the disclosure required by the securities laws necessarily served other constituencies as well, and over time, the laws were expanded to encompass more companies, ${ }^{283}$ permitting disclosure to investors to do the work of disclosure for the benefit of society as a whole.

The 1960s and 1970s then witnessed a series of scandals-including Watergate, the Pentagon Papers, and the sudden collapse of the respected Penn Central railroad - that simultaneously shook faith in the ability of corporate management to run private firms responsibly, and the ability of government to regulate them. ${ }^{284}$ Appealing to the same idea of corporate "publicness" that had motivated the Progressives, activists began agitating anew for corporate governance reforms that would constrain industry power. ${ }^{285}$ Disclosure, specifically, was advocated as a mechanism of creating accountability, ${ }^{286}$ which exhibited itself in a number of ways. In 1974, Congress passed the Freedom of Information Act, ${ }^{287}$ allowing the public to petition for access to federal agency records and information. In 1975, the Federal Trade Commission adopted a new "line of business" reporting initiative that sought detailed information from large conglomerates on individual business units, with the intention of publishing aggregated, anonymized analysis of industry trends. ${ }^{288}$ The 1975 Home Mortgage Disclosure Act required lending institutions to report data on mortgages issued and purchased, explicitly to allow local communities to identify instances of racial "redlining." 289

A movement for corporate disclosure designed for the broader public played out at the SEC. In 1971, a group of public-interest organizations petitioned the SEC to require that public companies disclose information about their impact on the environment, and statistics on the racial and gender makeup (2016).

282. Mariana Pargendler, The Corporate Governance Obsession, 42 J. CORP. L. 359, 372

283. Guttentag, supra note 151, at 166-68.

284. Pargendler, supra note 282, at 373-74; Gordon, supra note 13, at 1515; Robert L. Rabin, Federal Regulation in Historical Perspective, 38 STAN. L. REV. 1189, 1281 (1986).

285. See, e.g., RALPH NADER ET AL., supra note 278, at 17; Donald E. Schwartz, The PublicInterest Proxy Contest: Reflections on Campaign GM, 69 MiCH. L. REv. 419, 422 (1971). (1976).

286. Russell B. Stevenson, Jr., SEC and the New Disclosure, 62 CORNELl L. REV. 50, 50-51

287. 5 U.S.C. $§ 552(2018)$.

288. Ravenscraft \& Wagner III, supra note 278, at 706-07 (describing how the initiative was abandoned in the face of industry opposition).

289. Charles M. Lamb et al., HMDA, Housing Segregation, and Racial Disparities in Mortgage Lending, 12 STAN. J. C.R. \& C.L. 249, 254-60 (2016). 
of their workforce. ${ }^{290}$ Though the organizations argued that such information was material to investors (both because it was relevant to financial performance, and because it would guide "ethical" investment), they also emphasized the information's relevance to other stakeholders, pointing out that disclosure would "further public education" 291 and "stimulat[e] greater concern in civil rights and related areas." ${ }^{292}$ The SEC issued a notice of rulemaking but ultimately made few changes, prompting the petitioners to sue in federal court. ${ }^{293}$ When they did so, they claimed standing not merely as shareholders, but also as citizens who enjoyed the environment, and as "public educators" whose "broad public education purposes require information." 294

The district court agreed that the SEC had not sufficiently considered the petitioners' request. Because "the rules adopted by the agency will have a broad impact not merely on those regulated companies, but also on the general public in a matter which vitally concerns the public and transcends economic issues," the court reasoned, the SEC should have issued a notice of rulemaking that detailed the breadth of the issues under consideration, so as to solicit comment from a wide range of society. ${ }^{295}$

After nineteen days' worth of hearings, ${ }^{296}$ in 1975 the SEC issued a release reaffirming its belief that "insofar as investing is concerned, the primary interest of investors is economic." The Commission concluded that "the Acts and the relevant legislative history also suggest that a prime expectation of the Congress was that the Commission's disclosure authority would be used to require the dissemination of information which is or may be economically significant," and that the Commission "is generally not authorized to consider the promotion of social goals unrelated to the objectives of the federal securities laws . ..."297 When the petitioners renewed their court challenge, the D.C. Circuit deferred to the SEC's authority, characterizing its "primary mandate" as the "financial protection of investors." 298

Despite this victory, the skirmish apparently left the SEC chastened. It subsequently reinterpreted its rules to require that public companies make expansive disclosures about environmental compliance, regardless of whether the dollar amounts involved were significant in light of the company's overall

290. Stevenson, supra note 286 , at 53-57.

291. Nat. Res. Def. Council, Inc. v. SEC (NRDC I), 389 F. Supp. 689, 692 (D.D.C. 1974).

292. Nat. Res. Def. Council, Inc. v. SEC (NRDC III), 606 F.2d 1031, 1037 (D.C. Cir. 1979).

293. Stevenson, supra note 286 , at 54.

294. NRDC I, 389 F. Supp. at 698. The district court accepted this account of the plaintiffs' standing. On appeal, the D.C. Circuit did not pass on this aspect of the district court's standing determination.

295. Id. at 700 .

296. Stevenson, supra note 286 , at 56.

297. Securities Act Release No. 5627 (Oct. 14, 1975). The SEC reserved that in the context of shareholder proposals specifically, "the primacy of economic matters . . is somewhat less."

298. Nat. Res. Def. Council, Inc. v. SEC (NRDC III), 606 F.2d 1031, 1049 (D.C. Cir. 1979). 
finances. ${ }^{299}$ Ultimately, however, the SEC concluded these new standards resulted in "less readable disclosure documents" that made it "more difficult to identify significant environmental proceedings," 300 and returned to an economic materiality standard. ${ }^{301}$

The SEC took a similarly meandering path with what came to be known as the "management fraud" cases. In the wake of Watergate, the SEC discovered that many corporations had established "slush funds" that they used for a variety of unsavory purposes, including corporate and political bribery around the globe (though always, at least in the view of corporate managers, in pursuit of corporate profits to benefit investors). These activities not only violated various anti-bribery statutes, but they also necessitated lying to investors, if only to cover up the true nature of corporate expenses. In some cases, however, the amounts involved were quite small, giving rise to a question whether they were "material." The SEC began to develop a theory of "qualitative" materiality, suggesting these actions bore on management integrity regardless of whether the dollar figures - either the bribes themselves, or the business to which they related-were material in the economic sense, and therefore would need to be disclosed. ${ }^{302}$ As one Commissioner characterized the move, "We are expanding our concept of materiality to include information which reflects upon the accountability of officers and directors, to shareholders and to a wider constituency." 303

That kicked off years of controversy, with detractors arguing that the SEC was using securities disclosure to shape corporate behavior in a manner that went beyond investor and market protection, ${ }^{304}$ and champions defending the practice for the same reason. ${ }^{305}$ Commissioners both current and former expressed their dismay, ${ }^{306}$ and ultimately the effort was abandoned by the early 1980 s. $^{307}$

299. Roberta S. Karmel, Disclosure Reform - The SEC is Riding Off in Two Directions at Once, 71 Bus. LAW. 781, 792 (2016).

300. Proposed Amendments to Item 5 of Regulation S-K Regarding Disclosure of Certain Environmental Proceedings, Securities Act Release No. 6315, 46 Fed. Reg. 25638, 25640 (May 4, 1981).

301. Karmel, supra note 299, at 792.

302. U.S. SEC. \& EXCh. COMm'N, Report ON Questionable AND Illegal Corporate Payments and Practices Submitted to the Senate Banking-Housing and Urban AfFairs COMMITTEE IN MAY 1976, at 15.

303. Roberta S. Karmel, Comm'r, Sec. \& Exch. Comm'n, Changing Concepts of Materiality 4 (Apr. 12, 1978), https://www.sec.gov/news/speech/1978/041278karmel.pdf [https://perma.cc/72XZQV5Q] (emphasis added).

304. Milton Freeman, The Legality of the SEC's Management Fraud Program, 31 Bus. L. 1295 (1976).

305. Stevenson, supra note 286, at 85-87.

306. Bevis Longstreth, SEC Disclosure Policy Regarding Management Integrity, 38 BuS. LAW. 1413, 1423-27 (1983); AA Sommer Jr., Therapeutic Disclosure, 4 SEC. REG. J. 263, 270-75 (1976).

307. James D. Redwood, Qualitative Materiality Under the SEC Proxy Rules and the Fifth Amendment: A Disclosure Accident Waiting to Happen or Two Ships Passing in the Night?, 1992 WIS. L. REV. 315. In reaction to the scandals, Congress passed the Foreign Corrupt Practices Act (FCPA) in 
Yet even as the SEC reaffirmed its focus on investors and its commitment to materiality as a financial concept, it also recognized that a corporation's social behavior can have economic relevance to the extent its activities are legally or morally risky enough to jeopardize either its finances or its goodwill. ${ }^{308}$ This stance became especially important because, beginning in the 1960s and continuing into the early 1970s, Congress passed a bevy of new laws designed to protect consumers, workers, and the environment from industrial harm. ${ }^{309}$ Each new statute gave rise to new corporate obligations and liabilities, thus triggering new disclosure obligations about corporations' social performance, if only to alert investors to their financial implications. ${ }^{310}$ The cumulative effect was to enhance disclosures of matters of general public interest even as they were filtered through an investor-centric lens. ${ }^{311}$

Efforts to expand corporate disclosures to serve stakeholder audiences did not stop with the SEC; rather, this period also saw a renewed interest in federal chartering. ${ }^{312}$ Though advocates vacillated between prioritizing the protection of investors and protection of noninvestor constituencies, those who sought reform on behalf of noninvestors often recommended disclosure for those audiences. $^{313}$

The most prominent proposal along these lines appeared in the 1976 book Taming the Giant Corporation, by Ralph Nader, Mark Green, and Joel Seligman. ${ }^{314}$ As relevant here, the authors railed against "corporate secrecy,"315

1977. Foreign Corrupt Practices Act of 1977, Pub. L. No. 95-213, 91 Stat. 1494 (codified as amended in scattered sections of 15 U.S.C. (2018)). Among other things, the Act required corporations to keep accurate internal books and records and prohibited them from bribing foreign officials. Though the FCPA is primarily enforced by the SEC, it does not impose new disclosure obligations.

308. Nat. Res. Def. Council, Inc. v. SEC (NRDC III), 606 F.2d 1031, 1061-62 (D.C. Cir. 1979); see also Karmel, supra note 303, at 4-5; Staff Report, supra note 129, at 277, 286-87; Sommer Jr., supra note 306, at 269-70 (recognizing that illegal payments may be material due to their riskiness, if not their absolute size).

309. Rabin, supra note 284, at 1284 (describing a "legislative eruption [that] affected virtually every sector of the economy").

310. Staff Report, supra note 129, at 247-48, 286-87.

311. This was especially true because during this period, the SEC expanded its disclosure requirements to capture soft information about corporate segments, trends, and plans. See Gordon, supra note 13 , at 1553-56. As a result, corporate securities filings dramatically increased in length and informativeness.

312. Pargendler, supra note 282, at 377; see also William L. Cary, A Proposed Federal Corporate Minimum Standards Act, 29 Bus. L. 1101 (1974); William L. Cary, Federalism and Corporate Law: Reflections Upon Delaware, 83 YALE L.J. 663 (1974); Joel F. Henning, Federal Corporate Chartering for Big Business: An Idea Whose Time Has Come, 21 DePAul L. Rev. 915 (1972); Richard W. Jennings, Federalization of Corporate Law: Part Way or All the Way, 31 Bus. L. 991 (1976); Donald E. Schwartz, Towards New Corporate Goals: Co-Existence with Society, 60 GEO L.J. 57 (1971).

313. See, e.g., Douglas Branson, Progress in the Art of Social Accounting and Other Arguments for Disclosure on Corporate Social Responsibility, 29 VAND. L. REV. 529 (1976); Flynn, supra note 199, at 94, 103-05; Mueller, supra note 205, at 111; Theodore Sonde \& Harvey Pitt, Utilizing the Federal Securities Laws to 'Clear the Air! Clean the Sky! Wash the Wind!', 16 How. L.J. 831 (1971).

314. NADER ET AL., supra note 278, at 133-79.

315. Id. at 133-36. 
and proposed that federally chartered corporations - which would include the largest companies, as measured by sales and number of employees ${ }^{316}$-issue a single annual report "equally available to shareholders, the SEC, and other interested persons," ${ }^{317}$ with a second corporate register to include additional details. The reports would include a variety of social disclosures, such as data about environmental impact, worker safety, political expenditures, and employment discrimination, as well as more granular financial information that was not required under the securities laws. ${ }^{318}$ These disclosures would inform not only ethical investors, but would also educate communities about the "hidden tolls local companies impose-such as pollution, discrimination or underpayment of taxes." 319 Disclosure would "help to loosen the tight embrace between government and business," and help understaffed government offices identify legal violations. ${ }^{320}$ As they argued, "[t]his dissemination process will ensure that citizens, investors, consumers, competitors, and employees will have access to the kind of data they need to make intelligent political and economic decisions." 321

These proposals eventually worked their way into the Corporate Democracy Act, introduced in the House of Representatives by Congressman Rosenthal in $1980 .{ }^{322}$ The Act, which covered businesses based on size rather than securities trading, ${ }^{323}$ sought to remedy the "limited nature . . . of information . . c currently required to be reported to shareholders, employees, government agencies, local communities and the general public" by requiring disclosures similar to those recommended by Nader, Green, and Seligman. ${ }^{324}$ Yet the SEC, which was to administer the disclosure provisions of the Act, objected on the grounds that the Commission had no special expertise or insight with respect to disclosures intended for noninvestor audiences regarding topics of limited financial relevance. ${ }^{325}$

Significantly, the Senate counterpart to the Corporate Democracy Act was Senator Metzenbaum's Shareholders' Rights Act, ${ }^{326}$ the only one of the two to

316. Id. at 240

317. Id. at 139 .

318. Id. at $140-65$.

319. Id. at 136 .

320. Id. at 136-37.

321. Id. at 140 .

322. H.R. 7010, 96th Cong. (1980). In introducing the Act, Congressman Rosenthal also described corporations as "private governments." 126 CONG. REC. 7634 (1980).

323. Similar to Nader's proposal, "large" was defined by reference to assets or sales, plus number of employees. Corporations with fewer than twenty-five stockholders were excepted from the Act's coverage. H.R. 7010, 96th Cong. (1980).

324. Id., tit. II. These reports were to be made available to "any member of the public upon request."

325. Staff Report, supra note 129, at 321-23. The Staff also contended that the proposal process presented a better opportunity for shareholders to seek noneconomic information, if only because then shareholders could work out the types of social information they needed, rather than have the SEC attempt to develop a standard. $I d$. at 277.

326. S. 2567, 96th Cong. (1980). 
receive hearings. As the title of the latter indicated, rather than make corporations more responsive to society as a whole, the Shareholders' Rights Act was designed specifically to enhance shareholder welfare. Instead of redefining the concept of a public company, the Act applied only to larger corporations that already were subject to securities reporting requirements. ${ }^{327}$ Though the Act itself was never passed in full, many of its specific provisions later became part of the federal securities laws. ${ }^{328}$

In sum, just as happened during the Progressive Era, a movement that began by seeking corporate transparency to the wider society was redirected toward disclosure to investors or, through new regulatory statutes, to government agencies. ${ }^{329}$ Yet that was enough to (at least temporarily) chill calls for further reform.

\section{The Modern Era}

Despite this history (or perhaps because of it), today's movement for greater corporate disclosure remains focused on information that can be plausibly portrayed as having economic significance to investors, with forthright calls for mandatory reporting for stakeholders having largely fallen out of favor. Commentators occasionally recommend public reporting along particular dimensions - such as environmental performance, ${ }^{330}$ workplace diversity and pay practices, ${ }^{331}$ mortgage lending, ${ }^{332}$ and corporate tax payments ${ }^{333}$ - in order to educate the public and shame bad actors, yet these requests for disclosure of isolated items only underscore the need for a comprehensive, rather than fragmented, system, both to give audiences a complete picture of corporate performance, and to ensure that burdens on businesses are considered holistically rather than piecemeal.

Though various organizations have developed reporting frameworks for social performance, these are usually pitched as voluntary, rather than mandatory, measures, especially in the United States. Even proposals to give employees and other constituencies more power within the corporate form-

327. The Act only applied to companies with assets or revenues above a certain threshold, and that also had 500 or more shareholders. At the time, 500 was also the threshold for triggering SEC disclosure obligations; that number has since been enlarged. See Jones, supra note 60, at 177.

328. Among other things, the Act imposed set standards for director independence, and required the creation of audit and nominating committees. These ultimately became federal law, in modified form, in the Sarbanes-Oxley Act of 2002 and the Dodd-Frank Act of 2010.

329. For example, the EEOC requires companies to report data about workforce diversity; environmental statutes require reporting of emissions data and other hazards. See supra Section I.A. The result is that companies report streams of compliance data to regulators on an ongoing basis. See Rory Van Loo, Regulatory Monitors, 119 CoLuM. L. REV. 369 (2019).

330. Case, supra note 70, at 438.

331. Eisenberg, supra note 67, at 1006; Cynthia Estlund, Extending the Case for Workplace Transparency to Information About Pay, U.C. IRVINE L. REV. 781, 783 (2014); Gowri Ramachandran, Pay Transparency, 116 PA. ST. L. REV. 1043, 1043 (2012); Williams, supra note 28, at 1731.

332. Lamb et al., supra note 289289 , at 261.

333. Blank, supra note 110, at 109-20. 
such as by permitting them to vote for directors - tend to neglect the importance of disclosure tailored to noninvestor interests. ${ }^{334}$ For example, Elizabeth Warren recently introduced the "Accountable Capitalism Act," which would give employees of the nation's largest corporations the right to elect directors to the boards of their employers. But the Act does not propose any disclosures geared to employee concerns; indeed, because the covered corporations are defined based on gross receipts rather than public status, it is possible employees would be given these rights in private companies where no disclosure is required even to investors, meaning that employees would be exercising their votes in the dark. ${ }^{335}$

Yet even as the concept of generalized disclosure for stakeholders has been abandoned as a regulatory tool, the compromise struck in the 1930s and again in the 1970s - disclosure for investors, with benefits experienced by society at large - has proven unworkable. In fact, it has amplified the very investor-centric orientation of corporate managers that reformers sought to combat.

\section{The Perverse Effects of Using the Securities Laws as an All-Purpose}

Disclosure Vehicle

Because the securities laws are the only vehicle for generalized public disclosure, there is an incentive to load securities filings with information that, while potentially of great relevance to society, has minimal relevance to investors. This not only may impede investors' ability to locate and process the information they need, but also may distort information of legitimate public interest in order to justify its inclusion in securities filings. Finally, by centering investors, the securities laws weight the balance of power within the corporation in their favor, tilting managerial behavior toward wealth maximization, potentially at the expense of other constituencies.

\section{A. Concealing Motivations for Seeking Disclosure}

The current system is inherently dishonest. Advocates who want corporations to disclose information geared toward stakeholder audiences are

334. See, e.g., YoSIFON, supra note 17, at 198-204 (proposing that employees or consumers be granted corporate voting rights, but failing to discuss any accompanying change in disclosure regime). Kent Greenfield also recommends that workers and other stakeholders be granted a more formal role in corporate governance without proposing changes to the mandatory disclosure regime, see GREENFIELD, supra note 17, at 148-52, though he does recommend that workers be permitted to sue for fraud if management communicates false information, see $i d$. at 215-16.

335. S. 3348, 115th Cong. (2018). Senator Tammy Baldwin has similarly offered a bill that would enfranchise corporate employees, but only in companies that have chosen to list on a stock exchange. See S. 2605, 115th Cong. (2018). As a result, employees would necessarily have access to the SEC disclosures geared to investor audiences that are triggered by stock exchange listing, but would not, in Sen. Baldwin's proposal, be entitled to any additional disclosures aimed at noninvestor, employee audiences. 
encouraged to conceal their true motives, which by definition inhibits attempts to fully communicate both the need for the information, and its significance to the broader (noninvestor) community.

There are two basic avenues available to those who seek greater disclosure from public corporations. The first is to persuade the SEC (or Congress) to require such disclosure. Because the SEC has taken the position that "materiality" refers to information that has economic significance, ${ }^{336}$ most appeals for new rulemaking focus on the relevance of the requested information to corporate performance, ${ }^{337}$ regardless of the advocate's true interest. This, of course, is the reason why the sustainability debate discussed above is so contentious.

The second mechanism is to press for voluntary disclosure, typically by submitting a shareholder proposal to the targeted corporation under Exchange Act Rule 14a-8. ${ }^{338}$ That rule permits a sponsoring shareholder to include items on the corporate proxy ballot for all shareholders to vote on, and though proposals are usually framed as advisory requests to management rather than binding commands, corporations typically find it expedient to bow to shareholders' expressed wishes. But Rule 14a-8 has its limits, namely, it cannot be used for proposals that would be illegal for managers to implement. ${ }^{339}$ Because managers are generally believed to operate under a fiduciary duty to maximize shareholder wealth, ${ }^{340}$ any $14 \mathrm{a}-8$ proposal that explicitly called for management to take action based on ethical, rather than business, reasons would be on shaky legal ground. Even apart from that concern, the same dynamics regarding shareholder priorities discussed in Section II.B are in play. Rule 14a-8 proposals cannot succeed unless a critical mass of investors vote in favor of them, but because so many investors operate under a mandateexplicitly or implicitly - to maximize financial returns, appealing to them requires that proponents make their case in terms of the financial relevance of the information sought. The upshot is that investors who submit $14 \mathrm{a}-8$ proposals seeking greater corporate disclosure routinely, and fairly transparently, misrepresent their motives.

Consider recent proposals submitted to pharmaceutical companies by the UAW Retiree Medical Benefits Trust, a fund that provides health care plans to union members. The Trust sought explanations for the usurious rates often

336. See supra Section II.B.

337. Choudhury, supra note 170, at 212; Esty \& Karpilow, supra note 161, at 671 ; Ho, supra note 161, at 414-23; Cynthia A. Williams \& Jill E. Fisch, Request for Rulemaking on Environmental, Social, and Governance Disclosure (Oct. 1, 2018), https://www.sec.gov/rules/petitions/2018/petn4730.pdf [https://perma.cc/8BRN-VQJT].

338. 17 C.F.R. $\S 240.14 a-8(2019)$.

339. Id. $\S 240.14 \mathrm{a}-8(\mathrm{i})(2)$. Additionally, proposals must concern aspects of the business that are financially significant. See id. § 240.14a-8(i)(5); SEC Staff Legal Bulletin 14I (Nov. 1, 2017).

340. See, e.g., Exec. Order No. 13868, 84 Fed. Reg. 15495 (Apr. 10, 2019). The wealth maximization norm is accepted by most commenters, although it continues to generate a substantial amount of debate. See YOSIFON, supra note 17, at 60-95. 
charged for specialty drugs, and justified its proposals on the ground that these pricing strategies may anger the public and cause legislative backlash, to the ultimate detriment of the companies that employ them. ${ }^{341}$ But it seems far more plausible that the Trust - which must fund medical expenses incurred by its beneficiaries - simply wanted to keep drug prices low, and hoped to use both the proposal process, and any information generated by it, to publicly shame the targeted companies. In this manner, the Trust sought to leverage securities disclosure into a mechanism for pressuring drug companies to change their behavior. ${ }^{342}$

A recent proposal submitted by the Episcopal Church to Anadarko Petroleum represents another example. The Church sought to have Anadarko report to shareholders on its process for identifying and addressing risks associated with human rights violations in its operations, purportedly out of concern that litigation, project delays, and reputational damage associated with such violations would "adversely affect shareholder value." 343 Though it is possible that the Church was simply trying to protect its economic stake in Anadarko, a more likely explanation is that - as a humanitarian organizationits concern was for the people affected by Anadarko's operations. ${ }^{344}$

This is not to criticize the Trust, the Church, or other proponents seeking disclosure of social information; it is simply to call attention to a form of prevarication that has become so routinized within the securities framework that it is treated as unremarkable. But these misrepresentations are not harmless; they are disabling. The need to emphasize financial risk and shareholder return inhibits a fuller discussion of the societal need for such information, let alone a serious balancing of the costs and benefits of requiring it.

The problem extends to academia, as well. With her classic article, The Securities and Exchange Commission and Corporate Social Transparency,

341. See Vertex Pharmaceuticals, Inc., SEC No-Action Letter, 2015 WL 109832, at *2-3 (Feb. 25, 2015); Gilead Sciences, Inc., SEC No-Action Letter, 2014 WL 6984699, at *9 (Feb. 23, 2015).

342. A similar campaign successfully pressured Walmart to stop selling AR-15 rifles. Trinity Wall Street, an Episcopal parish and Walmart investor, sought to have shareholders vote on whether Walmart should withdraw the guns from its shelves. Walmart argued that the proposal was legally improper, leading to a court battle and multiple headlines. Though Walmart succeeded in excluding the proposal from the corporate proxy, see Trinity Wall St. v. Walmart Stores, 792 F.3d 323 (3d Cir. 2015), shortly thereafter it voluntarily withdrew the guns from its shelves, see Hiroko Tabuchi, Walmart to End Sales of Assault-Style Rifles in U.S. Stores, N.Y. Times (Aug. 26, 2015), https://www.nytimes.com/2015/08/27/business/walmart-to-end-sales-of-assault-rifles-in-us-stores.html [https://perma.cc/YA53-4JUG].

343. Anadarko Petroleum, SEC No-Action Letter, 2013 WL 6914372, at *6 (Jan. 22, 2014).

344. The fact that many sponsors of social proposals only hold a nominal stake in the targeted company provides further evidence that their concerns stem from their status as members of the community rather than as investors. For example, Harrington Investments, a socially responsible fund, recently sponsored a proposal that Coca-Cola disclose more information about sugar's health risks. Harrington has \$200 million in assets under management, and owns a Coca-Cola stake worth about \$4900. See Andrea Vittorio, Cola-Cola Faces Shareholder Activism on Sugar's Health Risks, BLOOMBERG L. (Feb. 11, 2019), https://www.bloomberglaw.com/document/X6QGBVIK000000 [https://perma.cc/7VQM-V7PY]. 
Cynthia Williams became one of the more prominent advocates for the use of the securities laws to force greater social disclosure in the "public interest." 345 However, the article explicitly advocates disclosure for investor audiences only. ${ }^{346}$ Williams's explanation for how disclosure to investors advances a public interest invokes only an unspecified notion of corporate accountability and the right of investors to choose how to allocate their dollars - which, she admits, is unlikely to influence corporate behavior. ${ }^{347}$ The natural implication is that social disclosures cannot serve the "public" interest by appealing to investors alone, and that, therefore, investors are not the appropriate audience at all. ${ }^{348}$ Yet rather than confront that fact - and the incongruity of using the securities laws as the vehicle for such disclosure - she leaves the critical question unanswered: What disclosures are needed for the public, distinct from investor, interest? ${ }^{349}$

In short, securities disclosure has a tail-wagging-the-dog problem: The social control that was once a byproduct of the regime has become, for many advocates, its central purpose. ${ }^{350}$ But the securities laws are not designed to make business transparent to the general public; they are designed to "provide full and fair disclosure of the character of securities sold in interstate and foreign commerce." 351 The SEC's mission is not to promote the general welfare, ${ }^{352}$ but to "protect investors, maintain fair, orderly, and efficient

345. Cynthia A. Williams, The Securities and Exchange Commission and Corporate Social Transparency, 112 HARV. L. REV. 1197, 1235 (1999).

346. See id. at 1237, 1242, 1284-89, 1294-95.

347. Id. at 1294.

348. Id. at 1221 (arguing that the Exchange Act was intended to promote "accountability to the public"); see also id. at 1295 (speculating that corporate managers want to avoid having their bad acts published in the New York Times).

349. As described above, it is common for academics to recommend disclosure to investors when they envision that the true audience is the general public. See supra Introduction; see also Hill, supra note 18, at 978-79. Virginia Harper Ho has argued that sustainability reporting should be mandatory because of its importance to investors, yet in her discussion of why companies may be disinclined to volunteer it, she highlights that information of significant relevance to society may nonetheless be of minimal relevance to the subject company. In this respect, Ho shifts from investor audiences to societal audiences without comment. Ho, supra note 161, at 441. Barnali Choudhury makes the opposite move, initially recognizing that social disclosures are sought for noninvestor audiences, but then recommending they be tailored to investor concerns. Choudhury, supra note 170, at 191, 212.

350. Langevoort \& Thompson, supra note 5, at 373-74.

351. Securities Act of 1933, Pub. L. No. 73-22, pmbl., 48 Stat. 74, 74; 15 U.S.C. $\S 77$ a et seq. (2018); see also Securities Exchange Act of 1934, 15 U.S.C. § 78b (2018) (declaring that the Act is "for regulation and control" of "transactions in securities as commonly conducted upon securities exchanges and over-the-counter markets").

352. Cynthia Williams has offered the most in-depth argument that the securities laws authorize the SEC to require corporate disclosure solely to serve the public interest, regardless of its relevance to financial return (though — as described above - she does not explain how the public interest is furthered by social disclosures aimed at an investor audience). Williams points out that the proxy provisions in the Exchange Act explicitly reference regulation in the "public interest," Williams, supra note 345 , at 1235 , which she interprets to mean that disclosures can extend beyond those intended specifically for investor protection. At the same time, she concedes that references to the "public interest" may be interpreted to mean prohibition of certain kinds of financial practices reviled at the time, such as self-dealing, overuse of leverage, and concentration of power among a handful of finance professionals. See id. at 1214, 1240, 1245 n.245. 


\section{Not Everything Is About Investors}

markets, and facilitate capital formation." ${ }^{353}$ Disclosure demands that rely upon the securities laws must therefore be couched in the language of investor protection and financial return, no matter how far-fetched the connection.

\section{B. Producing Less Informative Disclosures}

The failure to systematically grapple with the need for public-interest disclosure encourages what can only be described as scattershot disclosure requirements, inserted haphazardly into the securities laws whenever Congress (or a specific member) latches on to a particular issue. As a result, recent years have seen somewhat random disclosure add-ons, such as minor environmental liabilities, ${ }^{354}$ the safety record of mining companies, ${ }^{355}$ violations of sanctions against Iran, ${ }^{356}$ and the sourcing of certain minerals often obtained from wartorn areas, ${ }^{357}$ which are transparently intended more for the general public than for shareholders. ${ }^{358}$ Such proposals are often incoherent on their face. For example, the recently introduced DASHBOARD Act proposes that public companies disclose information about their use of consumer data in their securities filings, ${ }^{359}$ yet the sponsors explicitly intend the disclosures to be used

In fact, the Exchange Act's preamble makes clear that it is "transactions in securities" that are "effected with a national public interest." 15 U.S.C. § 78b (2018); see also Hillary A. Sale, New Public, supra note 59, at 138; Hillary A. Sale, Disclosure's Purpose, 107 GEO. L.J. 1045, 1049 (2019) [hereinafter Disclosure's Purpose] (discussing how the "public interest" referenced in the Exchange Act refers to the general benefits that follow from honest securities markets); Thel, supra note 45, at 389-92. Moreover, with respect to proxy voting specifically, the main concern at the time was directors' illegitimate perpetuation of their control through manipulation of, among other things, the proxy process, holding company structure, and issuance of nonvoting stock. See, e.g., Jill E. Fisch, From Legitimacy to Logic: Reconstructing Proxy Regulation, 46 VAND. L. REV. 1129, 1189-91 (1993); Loomis Jr. \& Rubman, supra note 51, at 154-155, 170; RIPLEY, supra note 228, at 77, 85-89, 94-98, $151,300-02$.

That said, as discussed above, prior to the enactment of the Securities Acts, there were numerous proposals for general corporate transparency, so it is likely that some of these ideas motivated the Acts themselves even if the Acts themselves did not extend as broadly as earlier proposals.

353. The Investor's Advocate: How the SEC Protects Investors, Maintains Market Integrity, and Facilitates Capital Formation, U.S. SEC. \& EXCH. COMM'N, http://www.sec.gov/about/whatwedo.shtml [https://perma.cc/X28K-YAP8]. Congress mandated that when the SEC engages in rulemaking, it must consider "the protection of investors, whether the action will promote efficiency, competition, and capital formation." National Securities Market Improvement Act of 1996, Pub. L. No. 104-290, § 106(b), 110 Stat. 3416, 3424.

354. 17 C.F.R. $\S 229.103$, Instruction 5C (2019).

355. 15 U.S.C. $\$ 78 \mathrm{~m}-2$ (2018).

356. Id. $\S 78 \mathrm{~m}(\mathrm{r})$.

357. Id. $\S 78 \mathrm{~m}(\mathrm{p})$.

358. Other similar types of disclosure items have been proposed. See H.R. 2364, 116th Cong. (2019) ("To amend the Securities Exchange Act of 1934 to require issuers to disclose in an annual report any substantial financial relationship with any manufacturer or dealer of firearms or ammunition."); H.R. 7089, 115th Cong. (2018) (“A Bill to amend the Securities Exchange Act of 1934 to require certain companies to disclose information describing any measures the company has taken to identify and address conditions of forced labor, slavery, human trafficking, and the worst forms of child labor within the company's supply chains.").

359. S. 1951, 116th Cong. (2019). 
by consumers and for antitrust enforcement, ${ }^{360}$ with little explanation of how this information is relevant to an investor audience. (Naturally, because only public companies are subject to the requirement, its use as a consumer protection and antitrust enforcement tool is limited.) ${ }^{361}$ Another proposal would require publicly traded corporations to disclose political spending not only in their securities filings, but also on their corporate website, ${ }^{362}$ demonstrating that the disclosure is not aimed at a purely investor audience. But if that is the case, there is no reason it should apply exclusively to publicly traded companies.

These types of items would almost certainly be more effective if presented as part of a systematic report on companies' overall social performance, with different metrics emphasized for different industries. But because there is no framework for thinking about social disclosure as part of a general regulatory system, advocates are incentivized to slip items targeted to their idiosyncratic interests into legislation whenever they can manage it. ${ }^{363}$

Moreover, because the information sought is forced through the frame of corporate wealth maximization, only the investor-oriented aspects are emphasized, potentially distorting it and robbing it of its utility to other stakeholders. Steven Bank and George Georgiev demonstrate how this can occur in the context of pay ratio disclosures mandated by Dodd-Frank. ${ }^{364}$ In the wake of the financial crisis, Congress required that public companies disclose the ratio of CEO pay to median worker pay. The disclosure requirement was almost certainly intended as a shaming mechanism to combat income inequality ${ }^{365}$ but even Congress was not willing to say so forthrightly, creating a theoretical muddle for the SEC in designing rules for its implementation. ${ }^{366}$ The resulting regulations fail to generate useful information no matter who the target audience is perceived to be, and, worse, the information that is disclosed is misinterpreted and misused by a variety of stakeholders. ${ }^{367}$

It is not unusual for these types of items to stymie the SEC. With respect to mineral disclosures, for example, in defending its implementing regulations from a subsequent legal challenge, the SEC did not offer even a hypothetical justification for why the matter should be material to investors, or how

360. Mark R. Warner, Warner \& Hawley Introduce Bill to Force Social Media Companies to Disclose How They Are Monetizing User Data (June 24, 2019), https://www.warner.senate.gov/public/index.cfm/2019/6/warner-hawley-introduce-bill-to-force-socialmedia-companies-to-disclose-how-they-are-monetizing-user-data [https://perma.cc/3AXE-UYR7].

361. The bill also proposes that all companies, both public and private, make certain additional disclosures directly to users regarding how their individual data will be used.

362. See H.R. 1053, 116th Cong. (2019).

363. Cf. Hill, supra note 18, at 981 (warning that outrage at corporate behavior may be based on "fads" rather than principled consideration of appropriate business conduct).

364. Steven A. Bank \& George S. Georgiev, Securities Disclosure as Soundbite: The Case of CEO Pay Ratios, 60 B.C. L. REV. 1123, 1138-39 (2019).

365. Id. at 1140, 1148-1150; Langevoort \& Thompson, supra note 5, at 378.

366. Bank \& Georgiev, supra note 364, at 1138-39.

367. Id. at 1151-63, 1182-83. 
disclosure could advance any public policy. ${ }^{368}$ In the absence of a serious defense, the D.C. Circuit struck part of the regulation as inconsistent with the First Amendment. ${ }^{369}$

\section{Privileging Investors and Wealth Maximization}

Perhaps most fundamentally, the current system is inherently unstable. When investors are the sole intended audience of corporate disclosure, they have a unique, governmentally conferred advantage over the general public in influencing corporate behavior. Securities disclosure makes it easier for independent directors-less beholden to corporate management, and more beholden to shareholders - to monitor management performance, resulting in "an increasing orientation of the corporate purpose toward shareholder wealth maximization." 370 Meanwhile, other stakeholders' ability to condition corporate success on accommodation of their own interests is weakened. The result is that managerial incentives are misaligned: Managers are encouraged to favor investors to the detriment of other constituencies. The disclosure compromise falls apart. The more that investor interests and stakeholder interests diverge - and the more that investors are favored-the greater the calls for new mechanisms of corporate control, including new types of disclosure, ${ }^{371}$ that can be used to counter investors' influence.

This is especially true when it comes to private companies. As mandatory securities disclosures multiply, more companies choose to delay a public offering or transition to private status rather than bear the costs of public reporting. ${ }^{372}$ The tools of social control are weakened further, resultingironically - in more proposals for disclosures that would only burden public companies, creating another unsustainable cycle. But if all companies were required to issue a basic disclosure package regardless of their mechanisms for

368. See Brief of Respondent, Nat'l Ass'n of Mfrs. v. SEC, No. 13-5252, 2014 WL 6901084 (D.C. Cir. Dec. 8, 2014); Brief of Respondent, Nat'l Ass'n of Mfrs. v. SEC, No. 13-5252., 2013 WL 5756165 (D.C. Cir. Oct. 23, 2013). When issuing its regulations, the SEC candidly admitted that the statute's objectives "appear to be directed at achieving overall social benefits and are not necessarily intended to generate measurable, direct economic benefits to investors or issuers specifically. Additionally, the social benefits are quite different from the economic or investor protection benefits that our rules ordinarily strive to achieve." Conflict Minerals, Exchange Act Release No. 34-67716, 77 Fed. Reg. 56,350 (Sept. 12, 2012).

369. Nat'l Ass'n of Mfrs. v. SEC, 800 F.3d 518, 524, 527 (D.C. Cir. 2015).

370. Gordon, supra note 13, at 1540; see also Jeff Schwartz, De Facto Shareholder Primacy, 79 MD. L. REV. (forthcoming 2020), https://ssrn.com/abstract=3402486 [https://perma.cc/4ZAD-PC5H] (describing how securities disclosures permit shareholders to force management to focus on wealth maximization at the expense of other constituencies).

371. Hence the sustainability debate, and the various proposals for specific types of social disclosures described above. 2018),
[https://perma.cc/H7VU-Q8TZ].

372. Fontenay, supra note 119, at 448; Frank Partnoy, The Death of the IPO, ATLANTIC (Nov. 
raising capital, the incremental costs of going public would be reduced, which would stabilize the system (and encourage more public offerings). ${ }^{373}$

There is another unsettling side effect of relying on securities disclosures to inform the general public about corporate behavior. By reducing broader social issues to their impact on shareholders, we risk contributing to a discourse that suggests that investors are the only members of society who matter. Daniel Hemel and Dorothy Lund dub this "discursive harm," and, in the context of sexual harassment, raise the possibility that treating it as a corporate governance issue "runs the risk of equating the negative economic externalities of sexual harassment with the human tragedy that victims endure." 374 These effects are not harmless; for example, focusing on the business case for diversity rather than its moral justice may reinforce negative stereotyping. ${ }^{375}$

Making matters worse, because the securities laws define materiality and harm in terms of financial impact, there is no penalty when companies disclose false information about their sustainability. The noninvestor audiences who rely on such information have few remedies, ${ }^{376}$ and investors may not be entitled to damages unless they can establish its financial relevance, ${ }^{377}$ which may not be possible for some kinds of social information. Not only does this render ethical investment a legally unrecognized and unprotected category, ${ }^{378}$ but it also incentivizes issuers to "greenwash," thereby actively undermining

373. Cf. Cyrus Aghamolla \& Richard T. Thakor, Do Mandatory Disclosure Requirements for Private Firms Increase the Propensity of Going Public? (July 29, 2019) (unpublished article), https://ssrn.com/abstract=3428780 [https://perma.cc/QE84-QPW5] (finding that firms affected by a new FDA requirement to publicly disclose clinical trials were more likely to transition from private to public status).

374. Daniel Hemel \& Dorothy S. Lund, Sexual Harassment and Corporate Law, 118 Colum. L. REV. 1583, 1671 (2018).

375. Jamillah Williams, Breaking Down Bias: Legal Mandates vs. Corporate Interests, 92 WASH. L. ReV. 1473 (2017); see also Lisa M. Fairfax, The Bottom Line on Board Diversity: A CostBenefit Analysis of the Business Rationales for Diversity on Corporate Boards, 2005 WIS. L. REV. 795, 854 (arguing that the business case for diversity "may lead to the overextension, the marginalization, and even the devaluation of people of color").

376. GREENFIELD, supra note 17, at 187-89; Miriam A. Cherry, The Law and Economics of Corporate Social Responsibility and Greenwashing, 14 U.C. DAVIS BuS. L.J. 281, 289-92 (2014); Velikonja, supra note 54, at 1951-54. But see Nate Raymond, Massachusetts Top Court Rules Against Exxon in Climate Change Probe, REUTERS (Apr. 13, 2018), https://www.reuters.com/article/us-exxonmobil-climatechange/massachusetts-top-court-rules-against-exxon-in-climate-change-probeidUSKBN1HK20M [https://perma.cc/954S-QACP] (describing a lawsuit by the Massachusetts Attorney General alleging that Exxon lied to consumers about climate change).

377. Ann M. Lipton, Reviving Reliance, 86 FordHAM L. REV. 91, 112-23 (2017). Recently, New York State lost its bid to hold Exxon liable for false climate change disclosures because the state was unable to prove that investors, specifically, would have been misled. See John Schwartz, New York Loses Climate Change Fraud Case Against Exxon, N.Y. TIMES (Dec. 10, 2019), https://www.nytimes.com/2019/12/10/climate/exxon-climate-lawsuit-new-york.html [https://perma.cc/T4UP-65WY].

378. To some extent, it may even be actively disdained by courts. See id. at 133. 
Not Everything Is About Investors

attempts by the public to use corporate disclosures as a rallying point to spur change. ${ }^{379}$

\section{Thinking About Reform}

In the past, efforts to force corporate disclosure for the benefit of stakeholder audiences were subverted by arguments that it was unnecessary; disclosure directly to investors, and to regulators, would be sufficient for most purposes. Where it was not, it could be supplemented by specific, targeted disclosures to particular audiences as the need arose (such as product-specific, consumer-oriented disclosures at the point of sale, or details about workplace hazards at individual sites). Yet the continuing salience of this issue demonstrates that these arguments were in error; stakeholders have identifiable needs that are best served by a generalized disclosure system designed for their interests.

Though many companies voluntarily issue sustainability reports to stakeholders, ${ }^{380}$ and even private companies may choose to share limited economic information with the public (in response to scandal or otherwise), ${ }^{381}$ these are demonstrably insufficient to satisfy public demand. Voluntary reporting is notoriously incomplete and inconsistent, ${ }^{382}$ and the lack of legal mandate gives companies every incentive to make their disclosures as anodyne as possible. Illustrating the point, the law firm of Mayer Brown recently issued

379. Case, supra note 70, at 395 ("greenwashing" causes public to distrust voluntary environmental reporting and diminishes incentives for companies to report truthfully); Cherry, supra note 376, at 289; Fisch, supra note 161, at 948.

380. Ho \& Park, supra note 169, at 258; Fisch, supra note 161, at 944-46; Case, supra note 70 , at 395-401.

381. Hillary Sale argues that companies voluntarily disclose information as a condition of maintaining their social legitimacy. For example, before it formally adopted public-company status, Uber voluntarily disclosed both financial data and a private report on its internal governance deficiencies in response to various scandals. Sale, Social License, supra note 20, at 24-41. Yet Uber's actions do not establish that regulation is unnecessary: Uber's disclosures came after much of the harm had been done, and of course, society's interests include, but extend beyond, open lawbreaking. Moreover, Uber's newfound transparency did not extend to the details of its governance structure; even after these disclosures, news reports were still forced to speculate on how power was allocated within the company. See Katie Benner, How Uber's Chief Is Gaining Even More Clout in the Company, N.Y. TIMES (June 12, 2017), https://www.nytimes.com/2017/06/12/technology/uber-chief-travis-kalanickstock-buyback.html [https://perma.cc/7TNL-GWUA] (relying on a privately obtained buyback agreement to estimate the voting power of Travis Kalanick, Uber's founder); Julie Bort, Here's How Much Uber Stock Ousted CEO Travis Kalanick Actually Controls, BUS. INSIDER (Aug. 10, 2017), https://www.businessinsider.com/how-much-uber-stock-travis-kalanick-controls-2017-8

[https://perma.cc/E9GA-WP8D] (reporting that until revealed in a lawsuit, Kalanick's voting power was unclear). Nor can we rely on scandals to force transparency: the news is littered with instances of private company abuses of power that do not result in additional disclosures of internal operations. See, e.g., Alan Feuer, Hobby Lobby Agrees to Forfeit 5,500 Artifacts Smuggled Out of Iraq, N.Y. Times (July 5, 2017), https://www.nytimes.com/2017/07/05/nyregion/hobby-lobby-artifacts-smuggle-iraq.html [https://perma.cc/4FZG-CUHM]; Maddy Sauer \& Megan Chuchmach, Scandal-Ridden Blackwater Changes Name, ABC NEws (Jan. 30, 2009), https://abcnews.go.com/Blotter/Blackwater /story?id=6873331 [https://perma.cc/6VRL-7DSC].

382. Case, supra note 70, at 395; Choudhury, supra note 170, at 211; Fisch, supra note 161, at 947-52; Ho \& Park, supra note 169, at 266-68. 
a client recommendation that voluntary ESG disclosures be "carefully drafted" so that "aspirational efforts" are not "presented as formal commitments." 383

If there are any doubts that a mandatory-rather than voluntarydisclosure system is required, one need look no further than similar debates in the context of securities regulation, ${ }^{384}$ and then imagine a far less cohesive audience. Businesses have many private incentives to conceal information even from investors, a group with powerful and uniform interests upon whom they depend. Among other things, businesses may wish to use inside information to extract rents, and may fear handing advantages to competitors. Collective action problems prevent dispersed investors from bargaining for the information they need. Meanwhile, mandatory regimes help assuage business concerns that they will be disadvantaged relative to peers, and can standardize both the types of disclosure and their format in order to facilitate crosscompany comparisons. ${ }^{385}$

The disclosures recommended here present far greater problems of coordination and consistency than do those geared to investors. The target audiences are not only spread more widely with far more varied needs, but many are not in market relationships with the disclosing companies, inhibiting their ability to bargain for information directly. ${ }^{386}$ This point is implicitly recognized in the securities literature, where the fact that disclosures targeted to investors necessarily provide benefits to the rest of society is touted as a strong justification for mandatory reporting. ${ }^{387}$ Or, to put it another way, there is one mechanism for reconciling the interests of multiple constituencies with diverse priorities who are dispersed across society as a whole: government regulation.

Therefore, we need to talk seriously about designing a system of disclosure for noninvestor audiences. Below is a proposed outline of how such a system might work, and a discussion of potential objections.

\section{A. Designing the System}

\section{Requirements and Administration}

As described above, the European Union has instituted certain corporate reporting for stakeholder audiences; the regime proposed here takes the

383. 10 Tips for 10-Ks and Proxy Statements, MAYER BROWN (Jan. 3, 2019), https://www.mayerbrown.com/-/media/files/perspectives-events/publications/2019/01/10-tips-for-10-ksand-proxy-statements/files/update-10-tips_v7/fileattachment/update-10-tips_v7.pdf [https://perma.cc/AM35-3XUX].

384. Fox, supra note 279, at 1340; Sale, Disclosure's Purpose, supra note 352, at 1050.

385. Langevoort \& Thompson, supra note 5, at 376.

386. Case, supra note 70, at 420 (discussing the difficulty of coordinating constituencies affected by harmful behavior who number in the thousands or millions and are spread across multiple political jurisdictions).

387. Fox, supra note 279 , at $1358-59$. 
European system both as a model and as a point of contrast. The EU draws a distinction between social and financial reporting. Whereas all limited liability companies are required to disclose some information about their finances (with obligations increasing as the company scales up in size), ${ }^{388}$ only large companies designated as "public-interest entities" must issue sustainability reports aimed at a noninvestor audience. ${ }^{389}$ These "public-interest entities" are mostly publicly traded businesses listed on local stock exchanges, ${ }^{390}$ and though some countries have required sustainability reporting even of unlisted companies, ${ }^{391}$ the result is that, globally, reporting on social performance intended for a noninvestor audience is still conditioned, to some extent, on the presence of widespread public investment. ${ }^{392}$

This Article proposes reporting requirements that are both more and less expansive. To begin, this Article does not recommend generalized disclosure from the smallest companies because they are unlikely to have the kind of impact that creates a need for disclosure-based social control. Larger companies could be subject to scaled disclosures depending on size, ${ }^{393}$ taking into account gross receipts, number of employees, asset values, or some combination of the three. By these measures, disclosure would likely not be required until receipts or assets reached into hundreds of millions of dollars, or number of employees reached into the hundreds. ${ }^{394}$ Thus, unlike in Europe, the vast majority of American businesses would be exempt; only the largest 20,000 U.S. firms have more than $\$ 100$ million in annual revenues. ${ }^{395}$ These top firms would be the most obvious candidates for some degree of mandatory

388. See Bernard et al., supra note 3, at 96-98.

389. See Directive 2014, supra note 4; see also Global Reporting Initiative, Member State Implementation of Directive 2014/95/EU, https://www.globalreporting.org/resourcelibrary /NFRpublication\%20online_version.pdf [https://perma.cc/TU3A-6VTU] (explaining how the directive has been implemented at various countries).

390. See EUROPEAN COMMISSION, Non-Financial Reporting, http://europa.eu/rapid/pressrelease_MEMO-14-301_en.htm [https://perma.cc/W7FB-XRB2]; see also Afra Afsharipour, Redefining Corporate Purpose: Añ International Perspective, 40 SEATTLE U. L. REV. 465, 487 (2017) (India requires sustainability reporting of the largest publicly traded entities).

391. See Global Reporting Initiative, supra note 389.

392. Additional public disclosure requirements for particular areas of interest-such as pay transparency and environmental performance-may be imposed country by country. See, e.g., Workplace Gender Equality Agency, Gov'T OF AUSTL., International Gender Equality Reporting Schemes (Apr. 8, 2019), https://www.wgea.gov.au/sites/default/files/documents/2019-044\%20International\%20reporting\%20schemes_Final_for_web_0.pdf [https://perma.cc/84NW-QUVS]; Case, supra note 70 , at 402 .

393. Reporting burdens under the federal securities laws are lessened for smaller companies. 17 C.F.R. $\S 229.10$ (f) (2019).

394. Size might also be measured based on importance to local economies.

395. See U.S. SMall BuS. ADMIN., Firm Size Data, https://www.sba.gov/advocacy/firm-sizedata. There might be complications associated with defining a single firm. Because large companies may include smaller subsidiaries, some degree of line-drawing might be necessary to identify which firms have reporting obligations and how far they extend. The administering entity might create rules for joint reporting within corporate groups, so long as all required information is disclosed, as is done under European law. Directive 2014, supra note 4. 
stakeholder reporting. (By contrast, there are fewer than 4,000 publicly reporting firms listed on U.S. exchanges today.) ${ }^{396}$

At the same time, the notion that stakeholder reporting should be tied to public investment is precisely the problem that this Article identifies. For that reason, unlike in the EU, both social and financial information would be required of companies meeting the size threshold, regardless of whether their securities are available for generalized trading.

The general criticism of stakeholder-oriented disclosure is that it is too unconstrained; there are potentially hundreds of areas of interest. ${ }^{397}$ Yet in truth, most calls for stakeholder disclosure hinge on a few basic categories of information. These are financial information (including issues pertaining to tax payments, anticorruption measures, and antitrust compliance), corporate governance, environmental impact, labor relationships (including diversity, working conditions, and pay practices), political activity, and customer protection (transparency, safety, privacy). ${ }^{398}$ A working framework for stakeholder disclosure could begin with these topics and make appropriate adjustments as experience dictates.

To minimize burdens on business, the initial system could focus on information that has already been compiled internally, such as reports that companies are already required to file with government agencies, ${ }^{399}$ or financial and governance information likely to be on hand. ${ }^{400}$ Doing so would spare companies the additional burdens of data gathering, and would go a long way toward standardization. Just by way of example, at the federal level, companies must disclose diversity information to the EEOC, ${ }^{401}$ environmental information to EPA, ${ }^{402}$ workplace hazard and injury information to OSHA and to employees, ${ }^{403}$ and hazardous product information to the Consumer Product

396. Editorial, Where Have All the Public Companies Gone? Bloomberg (Apr. 9, 2018), https://www.bloomberg.com/opinion/articles/2018-04-09/where-have-all-the-u-s-public-companiesgone [https://perma.cc/S4GM-U6P9].

397. Elliott J. Weiss, Disclosure and Corporate Accountability, 34 Bus. LaW. 575 (1979); Staff Report, supra note 129, at 275.

398. There are several privately developed frameworks for voluntary stakeholder-oriented disclosure, Susan Gary, Best Interests in the Long Term: Fiduciary Duties and ESG Integration, 90 U. Colo. L. Rev. 731, 772-78 (2019), and these represent the basic categories of information. See, e.g., Global Reporting Initiative, Standards Download Center, https://www.globalreporting.org/standards/gri-standards-download-center [https://perma.cc/RT5CZHRH]. They are also recurring topics in shareholder proposal activity.

399. Estlund, supra note 69, at 396-97 (recommending disclosure to employees based in part on information already filed with regulators).

400. Many companies are subject to extensive regulation and keep detailed records of their activities for compliance purposes.

401. 29 C.F.R. $\S 1602.7$ (2019).

402. $\quad 40$ C.F.R $§ 704$ (2019); Case, supra note 70, at 384.

403. 29 C.F.R. $\S \S 1904.7,1904.39,1910.1200$ (2019). 
Safety Commission and FDA. ${ }^{404}$ These disclosures, and others in the same vein, could be summarized and compiled into a single report. ${ }^{405}$

Public companies, of course, necessarily report financial information and are under a legal obligation to keep accurate books and records, ${ }^{406}$ and privately held companies of the size contemplated here are certain to keep detailed accounts, and may even voluntarily report such information to their investors. ${ }^{407}$ These internal financial records likely track donations to political organizations and lobbying expenditures, all of which could also be reported publicly. Finally, companies collect and disclose financial information to the IRS. There is a rich literature devoted to the question whether corporate tax returns should be made public, ${ }^{408}$ and without wading too far into that debate, it would be a relatively simple matter for corporations to disclose basic information like cash taxes paid and effective tax rates, which today are difficult to discern even from public company SEC filings. ${ }^{409}$

Burdens could also be minimized by distinguishing between companies that already file disclosure documents with the SEC, and those that do not. Companies subject to securities disclosure requirements could incorporate those filings by reference into their stakeholder-oriented disclosures, thus avoiding unnecessary duplication. ${ }^{410}$ Privately held companies would file more complete reports, including basic organizational and financial data such as governance structure, income statements, balance sheets, business segments,

404. 16 C.F.R. $\S 1115.6$ (2019); 21 C.F.R. $\S \S 314.80,803$ (2019).

405. In some cases, this information may be reported to authorities in a fragmented fashion that, in raw form, may not be of much use to stakeholders, see Ho, supra note 161, at 452, but it is unlikely that simply aggregating data previously reported (such as firm-level aggregation of emissions data reported on a facility-by-facility basis) would impose many additional burdens on disclosing companies.

There are arguments that some of these reports would be useless to a generalized audience. For example, advocates have sought EEO-1 reports for years, see RALPH NADER ET AL., supra note 278, at 150; Williams, supra note 28, at 1690; and have been met with the objection that the reports do not contain sufficient data to make appropriate comparisons across firms. Weiss, supra note 397, at 600-01; Nat. Res. Def. Council, Inc. v. SEC (NRDC III), 606 F.2d 1031, 1041 (D.C. Cir. 1979). This objection is not entirely persuasive because no one is proposing the EEO-1 reports be disclosed in a vacuum; they would necessarily be accompanied by more robust disclosures about firm operations and peer companies, which would perhaps make comparisons easier. In any event, these are precisely the kinds of judgments a specialized agency could make when developing an initial disclosure framework.

406. 15 U.S.C. $§ 78 \mathrm{~m}(2018)$.

407. Fan, supra note 6, at 605-06.

408. See Blank, supra note 110, at 48-57 (summarizing the arguments).

409. Id. at 46; see also Allan Sloan, A Simple Tweak Could Tell Us How Much Tax America's Largest Companies Actually Pay, WASH. POST (Jan. 15, 2010), https://www.washingtonpost.com/business/economy/a-simple-tweak-could-tell-us-how-much-taxamericas-largest-companies-actually-pay/2020/01/15/5a53ad78-37d1-11ea-bf30-ad313e4ec754

story.html [https://perma.cc/AE2W-9DBB]; Nicola M. White, Companies, Investors Pan Planned Income Tax Disclosures, BLOOMBERG (June 10, 2019), https://news.bloombergtax.com/financialaccounting/companies-investors-pan-planned-income-tax-disclosures [https://perma.cc/685U-HQQB].

410. This is a common mechanism for federal securities reporting; companies that disclose information in one filing may often incorporate by reference into another filing. 
and geographic areas of operation, with smaller companies subject to correspondingly lighter burdens. ${ }^{411}$

Any such system would likely inspire objections that such data includes trade secrets or that disclosure would otherwise put disclosing companies at a competitive disadvantage. To some extent, this is a feature, not a bug; the securities laws already force disclosures that benefit competitors, and this is generally lauded so long as the effects are limited in scope. ${ }^{412}$ That said, these are precisely the kinds of judgments that regulators could make when deciding what information to publicize. ${ }^{413}$

The next issue concerns the appropriate regulator for such a system. This is likely a job for the federal government, rather than state regulators, if only to prevent the same "race to the bottom" that inspired the call for federal chartering and, eventually, a national securities disclosure system. ${ }^{414}$ Moreover, disclosure about isolated operations in particular localities would fail to paint a complete portrait of company behavior at the corporate level. ${ }^{415}$

There is currently no federal agency with the skills to manage the system contemplated here. The SEC is not equipped to manage disclosures intended for noninvestors (which is another reason the securities laws should not be used for that purpose). ${ }^{416}$ The Federal Trade Commission has broad experience studying business activity, but has fewer disclosure mandates. That said, the SEC and the FTC both have skills and experience that would be useful in developing a new system. Both study a wide range of industries, and the SEC in particular has expertise in developing standardized reporting for public audiences, balanced against the costs to businesses of complying with disclosure demands. Therefore, it might be appropriate to create a joint initiative that draws on the resources and knowledge of both agencies. The initiative could begin its work by studying how public information about corporations is used by noninvestor audiences, including surveying local regulators, as well as advocacy and trade groups, for their input as to how existing disclosures are used and the weaknesses in the current system. Based on the results of this survey, the initiative could develop a standardized

411. Though private companies of the size contemplated here may already employ an independent auditor, the rules could specify that audited financial statements are not necessary unless already in the company's possession. There are several similar requirements in the federal securities laws. See, e.g., 17 C.F.R. § 227.201(t)(1) (2019). Among European firms, there is evidence that companies strategically try to avoid triggering public disclosure requirements in order to avoid the additional costs of an audit. See Bernard et al., supra note 3, at 106.

412. See supra Section I.A.

413. SEC rules, for example, currently permit issuers to withhold certain information that would "affect adversely the registrant's competitive position." Regulation S-K, Item 101(c)(ii), 17 C.F.R. § 229.101(c)(ii) (2019).

414. Seligman, supra note 49 , at 45.

415. See Ho, supra note 161, at 452 (arguing that facility-by-facility environmental disclosures do not present a holistic portrait of company performance).

416. Staff Report, supra note 129, at 321-23; Dombalagian, supra note 151, at 682 n.157; Guttentag, supra note 151, at 194-95; Langevoort \& Thompson, supra note 5, at 374. 
Not Everything Is About Investors

framework that would permit meaningful comparisons across reporting companies.

\section{Enforcement}

One of the weaknesses of the current disclosure system is that unless a specific statement can be proved to impact security prices, there are few penalties for false reporting. ${ }^{417}$ A system of stakeholder-oriented corporate disclosure has the potential to carry with it a more robust enforcement mechanism.

The private enforcement mechanisms of the securities laws have come under heavy fire for encouraging strike suits ${ }^{418}$ and inflated damages calculations. ${ }^{419}$ To avoid replicating these pathologies, a system of stakeholderoriented disclosure could rely on agency enforcement and statutory penalties, perhaps supplemented by qui tam actions (which have been recommended in the securities context) ${ }^{420}$. This would allow Congress to tailor appropriate remedies and avoid the knotty problem of calculating actual damages, which may be unascertainable in this context. Notably, if disclosure obligations piggyback on existing reporting requirements, some of the enforcement heavylifting may already be accomplished by other regulatory regimes.

One lingering issue concerns how these disclosures would fit into the existing scheme of securities enforcement. Especially for publicly traded companies, any public statement could theoretically form the basis of a fraudon-the-market securities class action, even statements - such as the disclosures contemplated here - that are aimed at a noninvestor audience. ${ }^{421}$ One can easily imagine a scenario where a company discloses information not required under the federal securities laws, and yet, if it later turns out to be false, investors claim that the information impacted the market price of the stock. Companies may well balk at the prospect of mandated disclosures that expose them to additional securities fraud liability.

Yet the problem is perhaps more theoretical than real. Information that is material to investors should already be included in the federal securities filings of public companies; the disclosures contemplated here would, almost as a matter of law, be immaterial and courts can swiftly make that determination. ${ }^{422}$

417. See Section IV.C, supra.

418. Adam Pritchard, Halliburton II: A Loser's History, 10 DUKE J. CONST. L. \& PUB. POL'Y 27 (2015).

419. Donald C. Langevoort, Capping Damages for Open-Market Securities Fraud, 38 ARIZ. L. REV. 639 (1996).

420. Amanda M. Rose, Better Bounty Hunting: How the SEC's New Whistleblower Program Changes the Securities Class Action Debate, 108 Nw. U. L. REv. 1235 (2014).

421. Ann M. Lipton, Fact or Fiction: Flawed Approaches to Evaluating Market Behavior in Securities Litigation, 20 TENN. J. BUS. L. 741 (discussing how documents aimed at noninvestors can nonetheless form the basis of a securities fraud lawsuit).

422. Id. at 745-48 (describing the aggressiveness with which courts dismiss securities lawsuits on materiality grounds). Moreover, if the SEC is involved in designing the disclosure system, it can 
The risk is greater for nonpublic companies which have few or no federal disclosure obligations; for that reason, new disclosures may well be material to investors. That said, nonpublic companies are unlikely to be targets of fraudon-the-market class actions, ${ }^{423}$ and if individual investors can prove that they relied upon, and were harmed by, the company's intentional false representations, ${ }^{424}$ it is not troubling that disclosing companies would be subject to liability.

\section{B. Potential Objections}

\section{The Limits of Disclosure}

Disclosure is often proposed as a solution to intractable problems because it is easy and less controversial than more robust regulatory interventions, and it is derided for the same reasons. ${ }^{425}$ Critics point out that whether due to herd behavior or cognitive limitations, individual actors often cannot digest and apply the reams of information they are given. ${ }^{426}$ Disclosure thus "give[s] the appearance of "doing something" without actually limiting predatory or harmful practices. ${ }^{427}$

The disclosure recommended here, however, is not intended as a substitute for more robust regulation, but as a complement to it. Businesses often have inherent advantages over regulators; they have more concentrated resources, and are constantly evolving to evade formal restrictions on their behavior. Information collection is a first, and necessary, step in developing effective regulation, and public disclosure allows other constituencies to aid regulators in assimilating the information they are given.

Moreover, a system of stakeholder disclosure would not be intended to inform consumers and other market actors at the point of purchase, which is exactly the type of disclosure where cognitive limitations may undermine effectiveness. These disclosures are intended to be used for data analysis and organizing, so that interested and sophisticated actors-intermediaries such as journalists, academics, and advocacy groups - may interpret and disseminate

ensure harmonization so that information likely to be material to public company investors is included within the securities disclosure framework.

423. The fraud-on-the-market doctrine only applies to companies whose securities trade in "open and developed" markets, Basic Inc. v. Levinson, 485 U.S. 224 (1988), and is generally blamed for the prevalence of securities "strike" suits. See Pritchard, supra note 418, at 28.

424. Outside of a few highly specific contexts, scienter is a required element of claims based on false statements in connection with securities transactions. Ernst \& Ernst v. Hochfelder, 425 U.S. 185 (1976).

425. Ben-Shahar \& Schneider, supra note 25, at 682; Steven M. Davidoff \& Claire A. Hill, The Limits of Disclosure, 36 SeAtTLE U. L. ReV. 599, 605 (2013). 622

426. Ben-Shahar \& Schneider, supra note 25, at 686-87; Davidoff \& Hill, supra note 425, at

427. Davidoff \& Hill, supra note 425, at 604. 
Not Everything Is About Investors

information in more digestible form. Such disclosures can be very effective for educating the public and pressuring organizations to improve their behavior. ${ }^{428}$

\section{Unintended Consequences}

Poorly designed disclosure can do more harm than good. ${ }^{429}$ Most obviously, disclosure may have anticompetitive effects. It could facilitate coordination among competing firms and thereby encourage the formation of cartels, to the detriment of consumers and other market actors. Or disclosure may discourage innovation to the extent that disclosing firms believe that they must share their intellectual property with competitors.

There is some evidence for these effects; ${ }^{430}$ for example, mandatory disclosures may be associated with reduced $R \& D$ spending and product releases. ${ }^{431}$ But these narrow data points must be balanced against the more general anticompetitive effects of unbridled corporate power. There is reason to believe, for example, that the European economy has become more competitive, while the U.S. economy has become less so, in part due to the ability of large American companies to manipulate the regulatory system. ${ }^{432} \mathrm{~A}$ focus on microincentives at the firm level is penny-wise and pound-foolish to the extent it overlooks the collective advantage that secrecy confers on corporations over those who seek to cabin their power.

An additional concern may be that, rather than encourage best practices, ${ }^{433}$ disclosure may create a "race to the bottom," allowing an industry to settle on suboptimal norms by benchmarking poor practices against each

428. Numerous authors have described how intermediaries can help the public interpret complex information that is, or could be, disclosed under government mandate. Blank, supra note 110 , at 56 (corporate tax information); Case, supra note 70, at 393 (environmental performance); Dalley, supra note 76, at 1125; Estlund, supra note 69, at 377-78 (workplace information). As described above, the internet makes the services of such information intermediaries more powerful and effective.

429. Dalley, supra note 76, at 1127-28 (describing how disclosure may backfire, encouraging actors to game the system).

430. John Kepler, Private Communication Among Competitors (Nov. 12, 2018) (unpublished article), https://ssrn.com/abstract=3269911 [https://perma.cc/8LG4-UPS8]. On the other hand, the fact that firms try to avoid triggering mandatory disclosures in Europe suggests they fear increased competition, and do not welcome disclosure for purposes of cartelization. See Bernard et al., supra note 3 , at 109 . There is some evidence that firms are more likely to disclose information publicly when they have fewer incentives to compete, suggesting again that they view disclosure, on average, as handing advantages to competitors rather than providing shared benefits. See Ian D. Gow et al., Non-Answers During Conference Calls (Chi. Booth Research Paper No. 19-01, 2019), https://ssrn.com/abstract=3310360 [https://perma.cc/4X2A-QKXE]; Jihwon Park et al., Disclosure Incentives When Competing Firms Have Common Ownership, 67 J. ACCT. \& ECON. 387 (2019).

431. See Matthias Breuer et al., Mandated Financial Reporting and Corporate Innovation (Sept. 7, 2019) (unpublished article), https://ssrn.com/abstract=3449813 [https://perma.cc/4RLJ-5W75]. Pharmaceutical firms that go public, for example, tend to initiate fewer projects. This effect may be due simply to the pressures of a public shareholder base, but one study concluded that forced disclosure may also play a role. See Aghamolla \& Thakor, supra note 373.

432. See Thomas Philippon, The Great Reversal 9, 97, 106-09, 122-23, 174-75, 203 (2019).

433. Branson, supra note 313, at 652-53 (arguing that disclosure of social information will positively influence peer companies). 
other. ${ }^{434}$ For example, if a certain number of employees triggers disclosure obligations, firms may choose to hire contractors, thereby depriving potential workers of the legal benefits and protections they would have as direct employees. ${ }^{435}$

These administrative challenges are real, but they do not suggest that the answer is to keep the system as it is, where firms can opt in or out, often at will. The trick is simply finding the right regulatory balance. A robust joint employer test, for example, may make it harder for firms to artificially evade reporting obligations. It will remain the responsibility of the administering agencies to evaluate whether the costs and risks associated with specific disclosures are likely to outweigh the benefits. The SEC has been weighing these types of concerns for decades; ${ }^{436}$ there is no reason why the joint task force recommended here should not be able to continue that work, especially if it adopts an incremental, flexible, and experimental approach. And the fact that other countries have been able to develop systems of stakeholder-oriented disclosure establishes their feasibility.

\section{Constitutional Concerns}

It is very likely that a disclosure system of the kind advocated here would be challenged as a form of prohibited compelled speech under the First Amendment, or as an unreasonable search under the Fourth Amendment. ${ }^{437} \mathrm{~A}$

434. This has been a complaint in the context of disclosure of CEO pay under Dodd-Frank, see Davidoff \& Hill, supra note 425, at 624, and is one of the arguments against robust disclosure in other areas, see Blank, supra note 110, at 62-69 (tax); Estlund, supra note 69, at 365 n.46 (wages); Williams, supra note 28, at 1731 (diversity).

435. One study of mandatory disclosure in Europe found that some private firms incur significant costs to manage their asset values and thereby avoid triggering disclosure obligations. See Bernard et al., supra note 3, at 107, 110; see also Jeffrey L. Hoopes et al, Public Tax-Return Disclosure 14 (Nat'l Bureau of Econ. Research, Working Paper No. 24318, 2018), https://www.nber.org/papers/w24318 [https://perma.cc/832C-YECF] (manipulation of size in Australia to avoid disclosure of tax information).

436. For example, the SEC addresses concerns about proprietary information by permitting redactions of confidential material. See U.S. SEC. \& EXCH. COMM'N, New Rules and Procedures for Exhibits Containing Immaterial, Competitively Harmful Information (Apr. 1, 2019), https://www.sec.gov/corpfin/announcement/new-rules-and-procedures-exhibits-containing-immaterial [https://perma.cc/2FRR-TEB7].

437. It is not clear that informational disclosures filed with a regulatory agency and subsequently made available to the public should be categorized as speech-based regulation subject to First Amendment scrutiny in the first place. Jonathan H. Adler, Compelled Commercial Speech and the Consumer "Right to Know," 58 ARIZ. L. ReV. 421, 474 (2016); Robert H. Post, Compelled Commercial Speech, 117 W. VA. L. REV. 867, 880-81 (2015). Assuming that they are, the disclosure system would need to overcome objections that it is designed merely to satisfy the public's "idle curiosity." Am. Meat Inst. v. Dep't of Agric., 760 F.3d 18 (D.C. Cir. 2014) (en banc); see also Int'l Dairy Foods Ass'n v. Amestoy, 92 F.3d 67, 74 (2d Cir. 1996); Adler, supra, at 468. There may also be objections that compelled disclosure of sustainability information amounts to a mandatory self-condemnation, which has also been held to violate the First Amendment. See Nat'l Ass'n of Mfrs. v. SEC, 800 F.3d 518, 530 (D.C. Cir. 2015); Rebecca Susko, The First Amendment Implications of a Mandatory Environmental, Social, and Governance Disclosure Regime, 48 ENVTL. L. REP. NEWS \& ANALYSIS 10989, 10996 (2018). 
full accounting of the constitutional arguments is beyond the scope of this Article, but lurking in the background of both constitutional objections lies a broader theoretical question regarding the nature of the firm itself, and on whose behalf it should be run.

In recent cases, the Supreme Court has come close to constitutionalizing a stockholder-centric view of the firm, ${ }^{438}$ but this is a contestable position. As explained above, though all would agree that in a broad sense, firms exist to benefit society as a whole, ${ }^{439}$ a battle has long raged over whether this is best accomplished if firms are managed with a view to benefit equity owners - the stockholders - or whether they should be managed at the outset with a view to benefitting all of their stakeholders, including investors, creditors, employees, and consumers. ${ }^{440}$ Stockholders may be viewed as "owners" of the firm, with the concomitant right to direct corporate behavior, ${ }^{441}$ or they may be viewed as simply one of many types of claimants on corporate assets, with no particular privileged position in the corporate hierarchy. ${ }^{442}$

This matters because the constitutionality of the disclosures required by the federal securities laws is (usually) unquestioned. ${ }^{443}$ If investors - and specifically, stockholders - have no more exalted position than any other corporate stakeholder, then it is easier to justify imposing a disclosure framework intended to satisfy the informational needs of other corporate constituencies. ${ }^{444}$ Certainly if, for example, Elizabeth Warren's proposal for employee suffrage were to pass into law, it would be difficult to deny employees' need for information targeted to their concerns. Even without that

With respect to the Fourth Amendment, though business owners have a protectable privacy interest in business records, City of Los Angeles v. Patel, 135 S. Ct. 2443 (2015), documents may be sought "in respect to general or statistical investigations authorized by Congress," Okla. Press. Pub. v. Walling, 327 U.S. 186, 209 (1946). Occasionally courts deem regulatory disclosure requirements to be overly burdensome. Airbnb v. City of New York, 373 F. Supp. 3d 467 (2019).

438. Citizens United v. FEC, 558 U.S. 310, 370 (2010) ("Shareholders can determine whether their corporation's political speech advances the corporation's interest in making profits"); Haan, supra note 91, at 2679-80; Pollman, supra note 216, at 690.

439. See supra Introduction.

440. David Millon, Theories of the Corporation, 1990 DUKE L.J. 201, 220-222.

441. Robert Anderson IV, A Property Theory of Corporate Law (July 16, 2019) (unpublished article), https://ssrn.com/abstract=3421009 [https://perma.cc/A4S8-WH5P].

442. Stephen M. Bainbridge, The Case for Limited Shareholder Voting Rights, 53 UCLA L. REV. 601, 604-05 (2006); Margaret M. Blair \& Lynn A. Stout, A Team Production Theory of Corporate Law, 85 VA. L. REV. 247 (1999); Jonathan Macey \& Leo E. Strine, Jr., Citizens United as Bad Corporate Law, 2019 Wis. L. ReV. 451, 483-84.

443. But see Nat'l Ass'n of Mfrs. v. SEC, 800 F.3d 518, 530 (D.C. Cir. 2015); Larry E. Ribstein, The Constitutional Conception of the Corporation, 4 SUP. CT. ECON. REV. 95 (1995).

444. This is particularly so because the securities laws are aimed not only at stockholders, but also bondholders. Reves v. Ernst \& Young, 494 U.S. 56 (1990). Even as a theoretical matter, bondholders have never been elevated above other corporate constituencies such as employees. Managers usually owe fiduciary duties to equity holders (though not always, see, for example, 6 Del. Code. $§ 18-1104)$, but rarely do so for bondholders, see Catholic Educ. Programming Found. Inc. v. Gheewalla, 930 A.2d 92 (Del. 2007). Meanwhile, it has been argued that employers do owe fiduciary duties to workers who are not the targets of any system of generalized disclosure. Matthew T. Bodie, Employment as Fiduciary Relationship, 105 GEO. L.J. 819 (2017). 
kind of formal role in the corporate governance structure, employees, consumers, and other stakeholders are critical to firm operations, and thereby may be said to have a claim of equal dignity with respect to corporate information to that of purchasers of firm securities.

\section{Conclusion}

A century's worth of demands for corporate transparency has been repeatedly derailed with the argument that only investors, and not public audiences, need information. Today's economic environment belies that claim. Massive, socially impactful companies may do very well by their shareholders, but by operating out of the public eye, they can do significant harm to their employees, customers, and competitors. More generally, their privacy impedes our ability to understand our social and industrial landscape, and to shape it to better serve our communities.

Rather than warp the securities laws to serve purposes for which they were never intended, we should focus our efforts on developing a system of corporate transparency tailored to the needs of all stakeholders. In so doing, we can make disclosures more useful to all audiences - investors and the public alike-without imposing piecemeal, collectively burdensome obligations on disclosing companies. At the very least, there should be a national conversation about the informational needs of the public, and the systemic informational deficits created by the investor-oriented disclosure system we have today. 